\title{
VARIABILIDADE DA FERTILIDADE DO SOLO E NUTRIÇÃO MINERAL DO MILHO CULTIVADO SOB CERRADO
}

\author{
ZAQUEU FERNANDO MONTEZANO \\ Engenheiro Agrônomo
}

Orientador: Prof. Dr. TAKASHI MURAOKA

Dissertação apresentada à Escola Superior de Agricultura "Luiz de Queiroz", Universidade de São Paulo, para a obtenção do titulo de Mestre em Agronomia, Área de Concentração: Solos e Nutrição de Plantas.

PIR A C IC AB A

Estado de São Paulo - Brasil

Junho -2005 
Dados Internacionais de Catalogação na Publicação (CIP) DIVISÃO DE BIBLIOTECA E DOCUMENTAÇÃO - ESALQ/USP

Montezano, Zaqueu Fernando

Variabilidade da fertilidade do solo e nutrição mineral do milho cultivado sob cerrado / Zaqueu Fernando Montezano. - - Piracicaba, 2005.

$104 \mathrm{p}$.

Dissertação (mestrado) - - Escola Superior de Agricultura Luiz de Queiroz, 2005.

Bibliografia.

1. Agricultura de precisão 2. Cerrado 3. Fertilidade do solo 4. Milho 5. Nutrição mineral I. Titulo

$$
\operatorname{COD} 631.42
$$

"Permitida a cópia total ou parcial deste documento, desde que citada a fonte - 0 autor" 

A Deus,
digno de toda honra
e de toda glória
OFEREÇO

Aos meus pais, Domingos e Maria Rita Aos meus irmãos, Rosana e Eliezer Aos meus avós, Vito e Iracema, Gabriel (in memoriam) e Umbelina Aos meus familiares A minha namorada, Tania DEDICO 


\section{AGRADECIMENTOS}

Primeiramente a Deus, por ter me abençoado;

Ao amigo Edemar Joaquim Corazza por idealizar, motivar e participar desse projeto;

Ao professor Takashi Muraoka pela orientação acadêmica e amizade cultivada durante esses dois últimos anos;

Aos proprietários e amigos da Fazenda Alto Alegre Eloy Corazza, João Carlos Pagnunssatt, Heitor Jaime Corazza, Jucemar Pagnunssatt, Helder Antônio Corazza, José Luiz Pagnunssatt e Eliseu Pedro Corazza pela permissão e ajuda de mais este projeto de pesquisa;

Aos pesquisadores da Embrapa Cerrados Álvaro Vilela de Resende e Luciano Shozo Shiratsuchi pơ contribuírem com o conhecimento que possuem na área de Agricultura de Precisão;

Aos amigos Thiago Martins Machado e Fabiano Lago pela grande ajuda no trabalho de campo;

As amigas do Laboratório de Fertilidade do Solo e Nutrição Mineral de Plantas CENA/USP Marileuza A. Bassi Elias, Sandra T. P. dos Santos e Henriqueta M.G. Fernandes pelo respaldo nas análises laboratoriais;

Aos amigos e amigas da pós-graduação Pablo Rodrigo Hardoim, Juliano Gomes Pádua, Marcelo Galdos, Juliano Cury, Gean Carlos Silva Matias, Fernanda Latanze Mendes, Tatiana Marsola, Anderson Trevizam, Ivan Furlan, Felipe C. A. Villanueva, João Salvador, Hector M. Coraspe Leon, Vinicius Franzini, Denis Silva, Raul Sartori pelos momentos de descontração;

Ao Departamento de Solos e Nutrição de Plantas ESALQ/USP e a CAPES. 


\section{SUMÁRIO}

Página

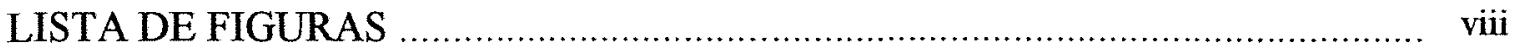

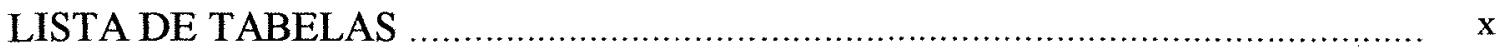

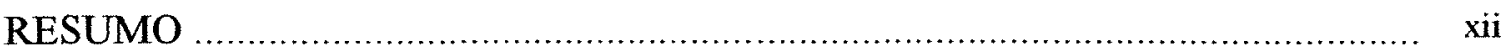

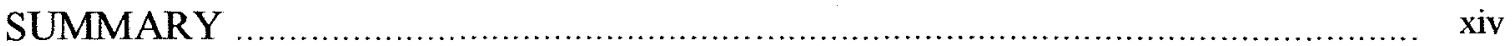

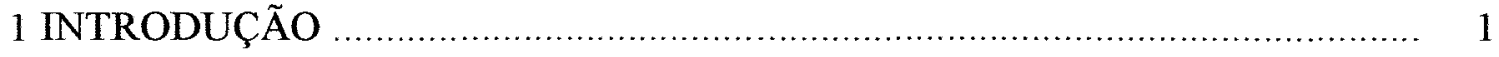

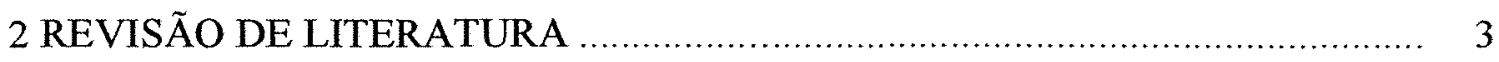

2.1 Caracterização da região de estudo ........................................................... 3

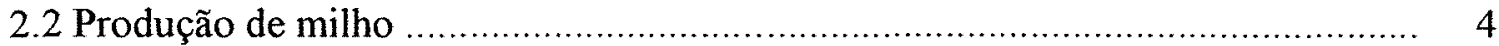

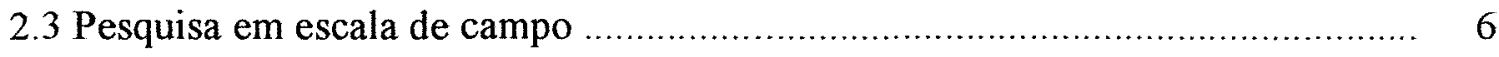

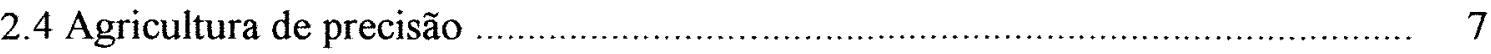

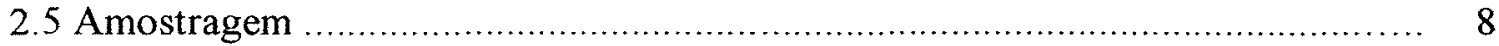

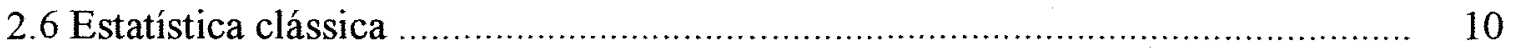

3 VARIABILIDADE DA FERTILIDADE DO SOLO DE UM TALHÃO MANEJADO HOMOGENEAMENTE ................................................... 16

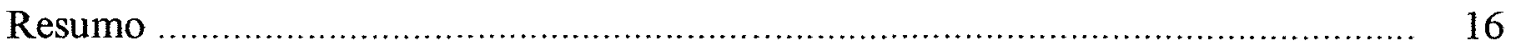

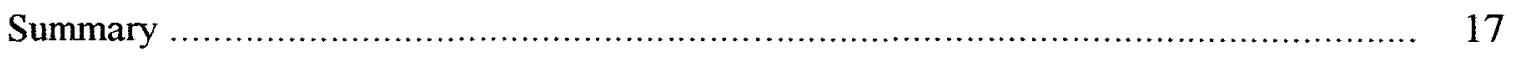

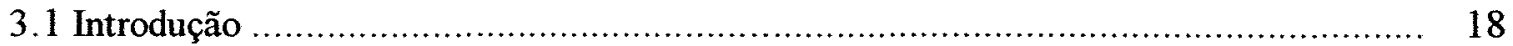

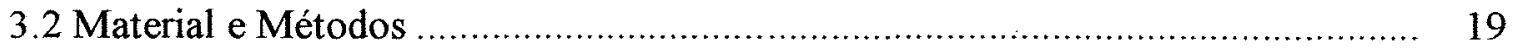

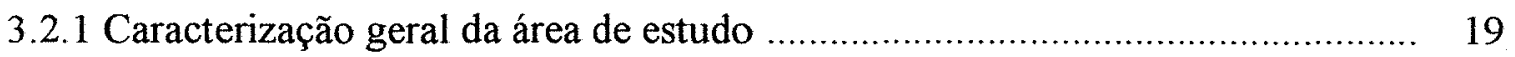

3.2.2 Análise química e física do solo ........................................................... 19

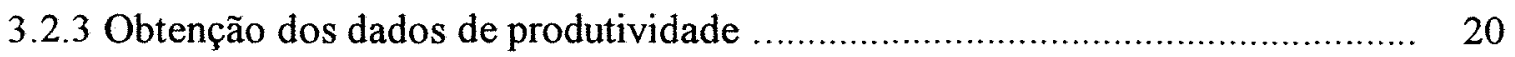

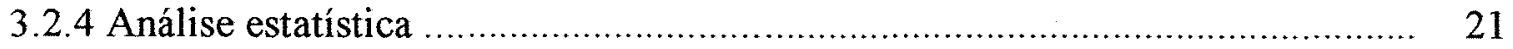




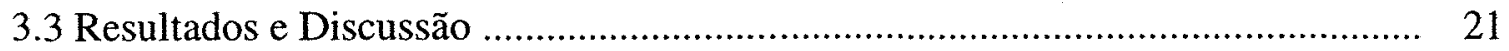

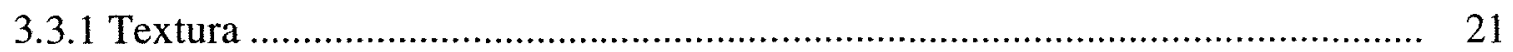

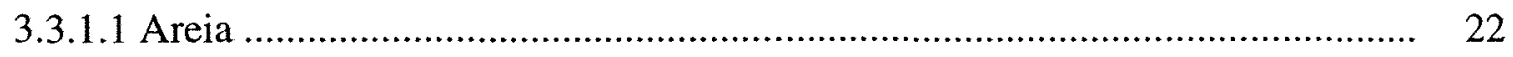

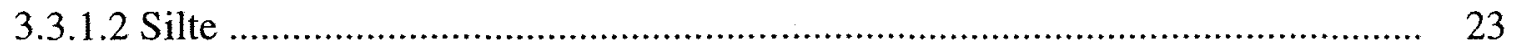

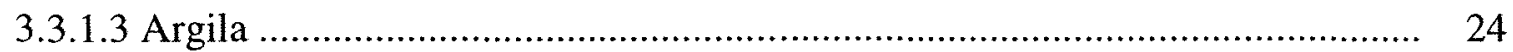

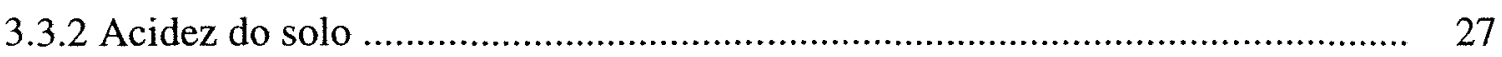

3.3.2.1 Acidez ativa ........................................................................................... 27

3.3.2.2 Acidez potencial ............................................................................ 29

3.3.3 Matéria orgânica e parâmetros de fertilidade ………...................................... 31

3.3.3.1 Matéria orgânica .................................................................................... 31

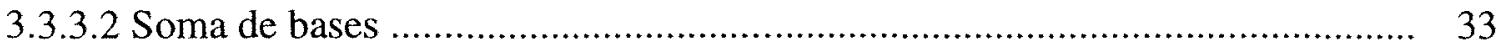

3.3.3.3 Capacidade de troca de cátions ................................................................. 34

3.3.3.4 Saturação por bases ................................................................................ 36

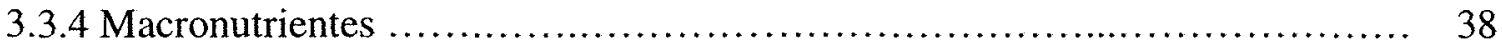

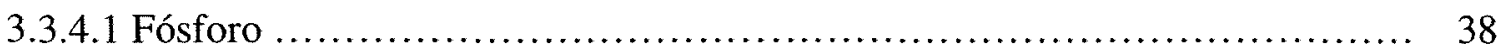

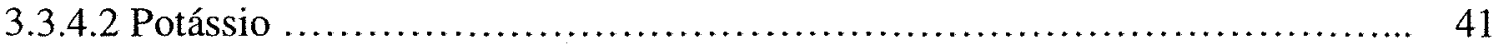

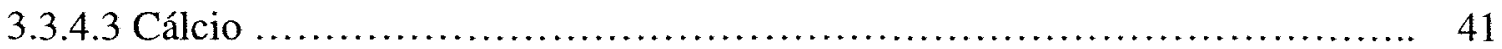

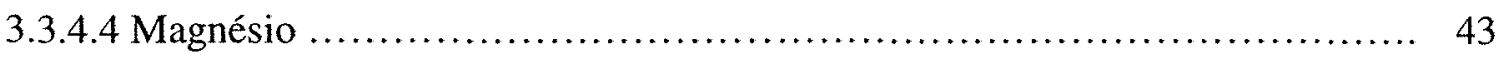

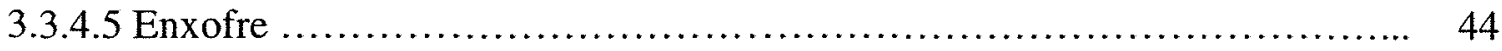

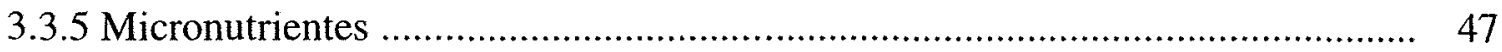

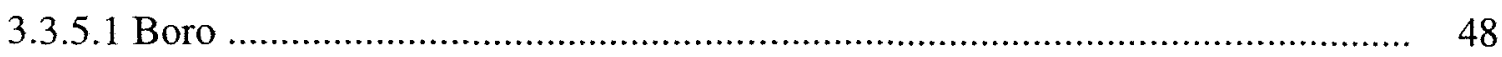

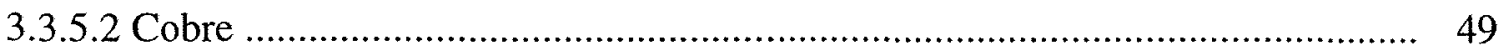

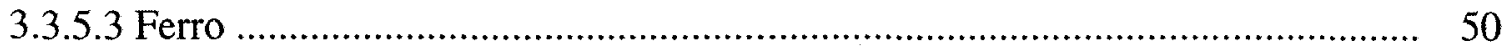

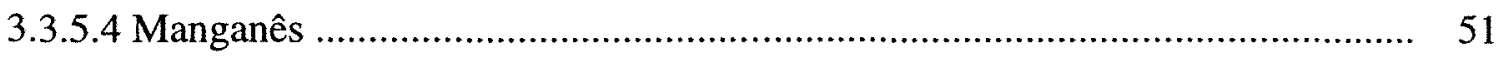

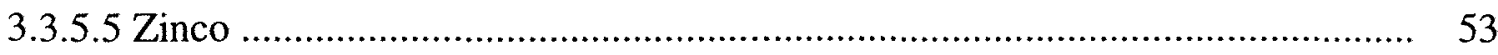

3.3.6 Correlação com a produtividade ................................................................... 55

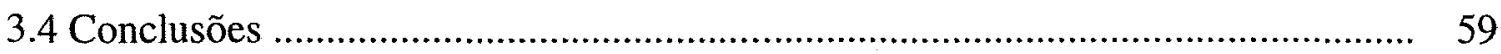

4 VARIABILIDADE DA NUTRIÇÃO MINERAL DE PLANTAS DE MILHO EM UM TALHÃO MANEJADO HOMOGENEAMENTE ………………............. 60

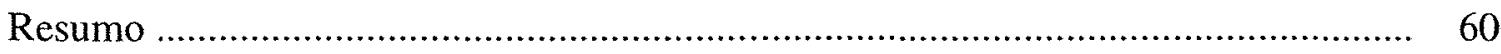




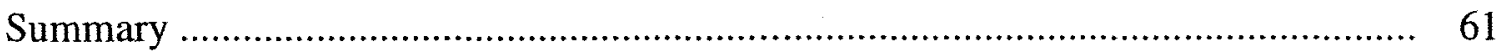

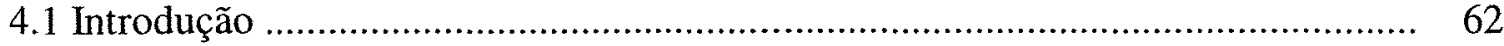

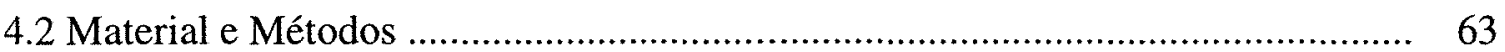

4.2.1 Caracterização geral da área de estudo ........................................................ 63

4.2.2 Análise química da planta .......................................................................... 64

4.2.3 Obtenção dos dados de produtividade ............................................................. 65

4.2.4 Análise estatística .................................................................................. 66

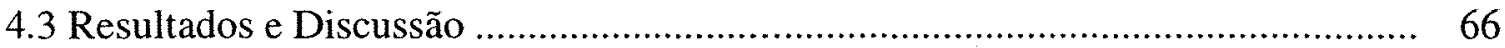

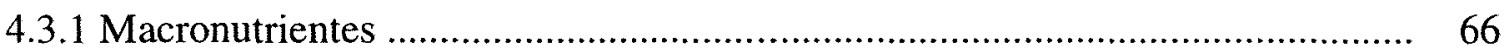

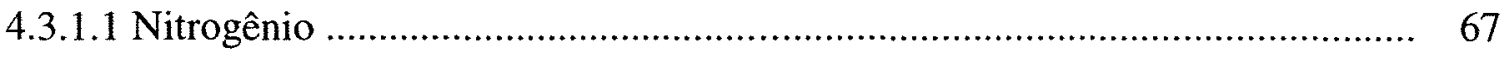

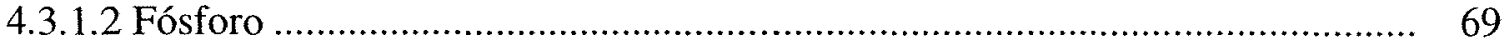

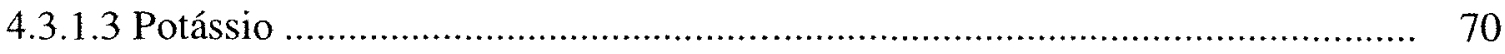

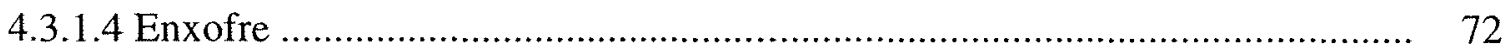

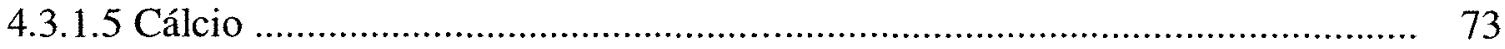

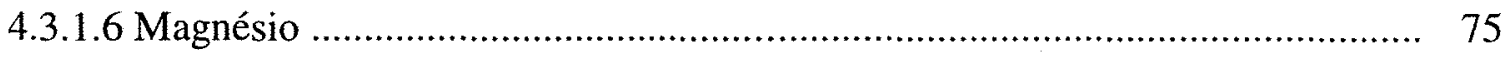

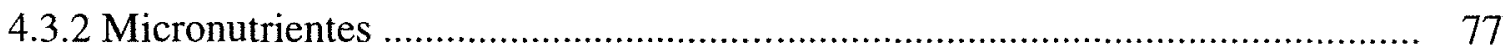

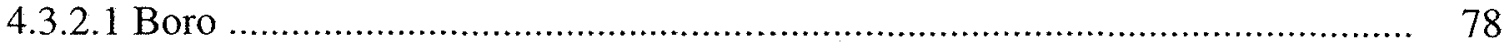

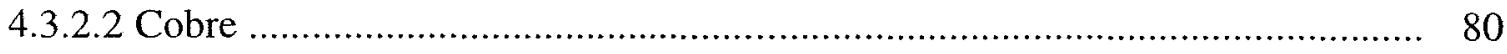

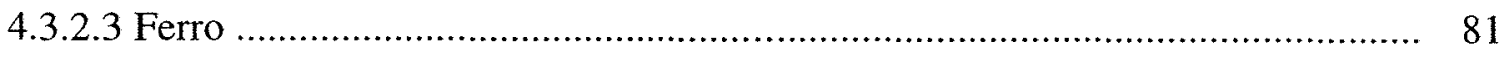

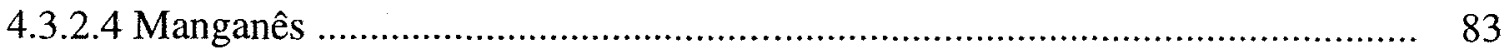

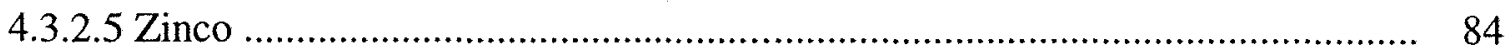

4.3.3 Correlação com a produtividade ………………........................................ 84

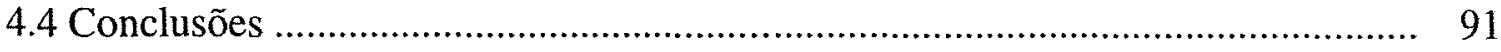

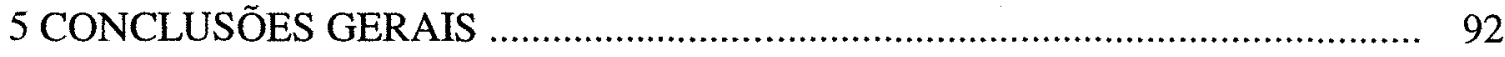

REFERÊNCIAS BIBLIOGRÁFICAS …………………............................... 93 


\section{LISTA DE FIGURAS}

Página

1 Histogramas de frequiência, retas de probabilidade normal e gráficos de

"Box-plot" para os resultados da análise textural ................................................ 26

2 Histogramas de freqüência, retas de probabilidade normal e gráficos de

"Box-plot" para os resultados de acidez ativa e acidez potencial

3 Histogramas de frequiência, retas de probabilidade normal e gráficos de

"Box-plot" para os resultados de matéria orgânica e soma de bases

4 Histogramas de freqüência, retas de probabilidade normal e gráficos de

"Box-plot" para os resultados de capacidade de troca catiônica a pH 7,0

e saturação por bases

36

5 Histogramas de freqüência, retas de probabilidade normal e gráficos de

"Box-plot" para os teores de fósforo e potássio

40

6 Histogramas de freqüência, retas de probabilidade normal e gráficos de

"Box-plot" para os teores de cálcio e magnésio

7 Histogramas de freqüência, retas de probabilidade normal e gráficos de

"Box-plot" para os teores de enxofre e boro 
8 Histogramas de frequiência, retas de probabilidade normal e gráficos de "Box-plot" para os teores de cobre e ferro

9 Histogramas de frequiência, retas de probabilidade normal e gráficos de "Box-plot" para os teores de manganês e zinco

10 Histogramas de freqüência, retas de probabilidade normal e gráficos de "Box-plot" para as concentrações de nitrogênio e fósforo

11 Histogramas de frequiência, retas de probabilidade normal e gráficos de "Box-plot" para as concentrações de potássio e enxofre 72

12 Histogramas de freqüência, retas de probabilidade normal e gráficos de "Box-plot" para as concentrações de cálcio e magnésio 75

13 Histogramas de freqüência, retas de probabilidade normal e gráficos de "Box-plot" para as concentrações de boro e cobre 79

14 Histogramas de frequiência, retas de probabilidade normal e gráficos de "Box-plot" para as concentrações de ferro, magnésio e zinco 


\section{LISTA DE TABELAS}

Página

1 Parâmetros estatísticos descritivos para a análise textural, na camada de 0 a $20 \mathrm{~cm}$, em Latossolo sob rotação soja/milho

2 Parâmetros estatísticos descritivos de acidez ativa e acidez potencial, na camada de 0 a $20 \mathrm{~cm}$, em Latossolo sob rotação soja/milho

3 Parâmetros estatísticos descritivos para os teores de matéria orgânica, soma de bases, capacidade de troca de cátions e saturação por bases, na camada de 0 a $20 \mathrm{~cm}$, em Latossolo sob rotação soja/milho

4 Parâmetros estatísticos descritivos para os teores de macronutrientes, na camada de 0 a $20 \mathrm{~cm}$, em Latossolo sob rotação soja/milho

5 Parâmetros estatísticos descritivos para os teores de $\mathrm{B}, \mathrm{Cu}, \mathrm{Fe}, \mathrm{Mn}$ e Zn, na camada de 0 a $20 \mathrm{~cm}$, em Latossolo sob rotação soja/milho

6 Correlação de Person entre os teores de macronutrientes e demais atributos químicos e físicos do solo com os dados médios de produtividade e altitude

7 Correlação de Person entre os teores de macronutrientes e demais atributos químicos e físicos do solo com os dados médios de produtividade e altitude 
8 Parâmetros estatísticos descritivos para as concentrações de macronutrientes, na folha das plantas de milho cultivadas sob sequeiro .............................................. 67

9 Parâmetros estatísticos descritivos para as concentrações de micronutrientes, na folha das plantas de milho cultivadas sob sequeiro .............................................. 77

10 Correlação de Person entre as concentrações dos nutrientes nas folhas de milho e os dados médios de produtividade e altitude

11 Correlação de Person entre as concentrações dos macronutrientes nas folhas de milho com alguns dos atributos físicos e químicos do solo

12 Correlação de Person entre as concentrações dos micronutrientes nas folhas de milho com alguns dos atributos físicos e químicos do solo 


\title{
VARIABILIDADE DA FERTILIDADE DO SOLO E NUTRIÇÃO MINERAL DO MILHO CULTIVADO SOB CERRADO
}

\author{
Autor: ZAQUEU FERNANDO MONTEZANO \\ Orientador: Prof. Dr. TAKASHI MURAOKA
}

\section{RESUMO}

O conhecimento da variabilidade da fertilidade do solo e nutrição mineral das plantas em escala de campo pode trazer importantes subsídios na racionalização de uso dos corretivos e fertilizantes do solo com grandes benefícios econômicos e ambientais. Este estudo de caso teve os seguintes objetivos: i) avaliar a variabilidade da fertilidade do solo por meio do fracionamento de uma área cultivada em pequenas células de manejo, ii) avaliar a variabilidade da nutrição mineral de plantas de milho por meio do fracionamento em pequenas células de manejo e, iii) avaliar a correlação da fertilidade do solo e da nutrição mineral das plantas com a produtividade do milho numa área cultivada e manejada homogeneamente. O estudo de caso foi conduzido na Fazenda Alto Alegre localizada em Planaltina - GO, numa área de 373 hectares de um Latossolo cultivada com milho na safra 2003/04. Traçado um polígono da área procedeu-se a divisão em 80 células de manejo de quatro hectares cada. A amostragem do solo seguiu uma diagonal com doze pontos para compor a amostra composta representativa dentro de cada célula. As coordenadas desses pontos foram obtidas e arquivadas. A amostragem das folhas seguiu o mesmo procedimento do solo. As determinações realizadas foram da fertilidade e textura do solo. Nas plantas de milho foram determinados os macronutrientes e micronutrientes. A produtividade para cada célula foi 
obtida por meio da colhedora equipada com Sistema de Posicionamento Geográfico (GPS) e monitor de rendimento de grãos. $\mathrm{Na}$ análise da variabilidade dos dados foram considerados parâmetros estatísticos descritivos e análise de regressão linear simples. A variabilidade foi considerada alta para o fósforo disponível, cobre e zinco; média para matéria orgânica, enxofre, cálcio, magnésio, acidez potencial, soma de bases, capacidade potencial de troca de cátions, saturação por bases, boro, ferro e manganês e baixa para pH e potássio. A variabilidade da concentração dos nutrientes na folha indicadora do milho foi considerada baixa para o nitrogênio, fósforo, potássio, enxofre e magnésio; média para o cálcio, boro, ferro, manganês e alta para o cobre. Os coeficientes de correlação linear foram significativos e positivos para a matéria orgânica e boro versus produtividade do milho. Contudo, para cobre, manganês e zinco foram significativos e negativos. Os coeficientes de correlação linear entre os atributos de nutrição mineral versus produtividade foram significativos e negativos para o cobre, manganês e zinco. Esses resultados estão diretamente ligados ao fornecimento anual desses micronutrientes juntamente com as adubações anuais e a média acidez do solo. A altitude mostrou ter uma relação mais direta com os atributos de nutrição mineral do milho do que os dados de produtividade. Em estudos de escala de campo normalmente não é possível isolar ou medir todos os fatores bióticos e abióticos que influenciam na produção da cultura. Entretanto, verificou-se neste estudo de caso que o conhecimento da variabilidade da fertilidade do solo, nutrição mineral de plantas e produtividade pode fornecer importantes subsídios na racionalização do uso de insumos e manejo da área considerada. 


\title{
VARIABILITY OF SOIL FERTILITY AND MINERAL NUTRITION OF CORN GROWN IN CERRADO (SAVANNAH)
}

\author{
Author: ZAQUEU FERNANDO MONTEZANO \\ Adviser: Prof. Dr. TAKASHI MURAOKA
}

\section{SUMMARY}

The acquaintance on the variability of soil fertility and mineral nutrition of crops grown in field scale may bring important subsidies for rationalizing the use of fertilizers and soil amenders, with great economic and environment benefits. The objectives of this case study were: a) to evaluate the soil fertility variability through the fractionation of a commercially grown corn field into small management cells; b) to evaluate the corn plant mineral nutrition variability through the fractionation of a commercially grown corn field into small management cells. c) to evaluate the correlation of soil fertility and plant mineral nutrition with grain productivity of corn grown in homogeneously managed area. The study was carried out in Alto Alegre farm in Planaltina, GO, Brazil, in a Typic Dystrarox soil under cerrado (savannah) in an area with 373 ha of corn crop grown during 2003/4 period. After outlining a polygon of area it was divided into 80 management cells of 4 ha each. The soil sampling followed a diagonal with twelve points to constitute a representative composite sample within each cell. Diagnostic leaf samples were collected form three plants per each twelve point to constitute a representative composite sample. The co-ordinates of these points were obtained and recorded. The soil samples were analyzed for texture and soil fertility and leaf samples for macro and micronutrients. The yield for each cell was obtained with a harvester equipped with GPS and grain yield monitor. For data variability analysis the descriptive 
statistic parameters were considered. The simple linear regression analysis of soil fertility versus corn grain yield data was applied. The variability was considered high for available phosphorus, copper and zinc contents; medium for soil organic matter, sulphur, calcium, and magnesium content, potential acidity, sum of bases, CEC, base saturation, boron, iron and manganese content and low for soil $\mathrm{pH}$ and potassium content. The linear correlation coefficients (LCC) were significants and positives for soil organic matter and boron content versus corn yield. However, the LCC for copper, manganese and zinc content were significants and negatives. The variability of nutrient content in the diagnostic corn leaves were considered low for nitrogen, phosphorus, potassium, sulphur and magnesium content; medium for calcium, boron, iron, manganese; and high for copper. The linear correlation coefficients between the mineral nutrition versus grain yield were significants and negatives for copper, manganese and zinc. These results are directly linked with annual supplying of these micronutrients and medium soil acidity. The correlation of altitude with yield was positive, however the altitude showed to have more direct relationship with corn mineral nutrition than with yield data. Although it is not possible to isolate or measure all the biotic and abiotic factors affecting the yield in field scale study, the knowledge on soil fertility variability and grain productivity may provide important subsidies for rationalizing the farm input use. 


\section{INTRODUÇÃO}

A região do Cerrado é o maior Bioma do País depois da Floresta Amazônica, com 204 milhões de hectares e com grande importância no cenário agrícola nacional e mundial.

Pressão por parte dos grupos ambientalistas projeta para o futuro melhoria no manejo das culturas sob Cerrado, a fim de se obter produções elevadas sem necessitar da simples incorporação de novas áreas ao setor produtivo.

$\mathrm{O}$ suprimento de quantidades adequadas de nutrientes minerais somado ao balanço nutricional e aliado ao conhecimento prévio da variabilidade, pela qual atributos do solo e das plantas estão sujeitos, estão entre os fatores mais importantes na busca por altas produções. Porém, uma infinidade de outros fatores ambientais está envolvida direta e indiretamente no desempenho produtivo das culturas no campo.

O desenvolvimento de pesquisas em escala de campo tem auxiliado na melhoria dos programas de manejo em lavouras comerciais além de atrair um número crescente de pesquisadores e produtores que passaram a adotar esta nova proposta.

Novas tecnologias estão sendo utilizadas nas experimentações agronômicas a fim de melhor identificar os padrões de variabilidade dos atributos do solo e das medidas de produtividade das culturas. $O$ conhecimento destes padrões auxilia no planejamento de um manejo cultural variável dos talhões e avalia também aqueles que são trabalhados de maneira uniforme.

A aplicação uniforme de fertilizantes na condução de talhões em áreas comerciais cultivadas há vários anos necessita ser investigada para gerar informações que auxiliem na racionalização do manejo da fertilidade do solo. 
O conhecimento da variabilidade dos atributos de fertilidade do solo e de nutrição mineral de plantas associando à produtividade da cultura e exportação dos nutrientes pelos grãos produzidos, pode auxiliar no aumento da eficiência de uso dos fertilizantes e diminuição dos riscos ambientais pelas contaminações dos recursos hídricos, por exemplo.

Atualmente algumas empresas prestam serviços de mapeamento da fertilidade do solo e aplicação de corretivos e fertilizantes a taxas variáveis baseados em diferentes malhas de amostragem. Entretanto, ainda não há resultados técnicos consistentes ou definitivos das operações e recomendações realizadas e do seu retorno econômico.

Diante deste contexto, este estudo de caso teve como objetivo avaliar a variabilidade da fertilidade do solo e da nutrição mineral das plantas de milho por meio do fracionamento de uma área de produção comercial em pequenas células de manejo, e avaliar a correlação dos atributos de fertilidade do solo e de nutrição mineral com os dados de produtividade do milho para cada célula de manejo considerada. 


\section{REVISÃO DE LITERATURA}

\subsection{Caracterização da região de estudo}

O Cerrado brasileiro faz parte do ecossistema das savanas que ocupa grande porção da região tropical do mundo. No Brasil o Cerrado ocupa uma área heterogênea e não contínua de aproximadamente 204 milhões de hectares, ou seja, 23\% do território nacional. Sua distribuição fisiográfica revela que o Cerrado ocupa extensas áreas nos Estados de Goiás, Distrito Federal, Mato Grosso do Sul, Minas Gerais e Piauí. Em termos comparativos pode-se mencionar que o Cerrado ocupa uma área superior a dois terços da área coberta pela Floresta Amazônica, sendo o segundo ecossistema brasileiro em termos de dimensão (Goedert, 1989).

O Cerrado ocorre, geralmente, em áreas de relevo plano ou suave ondulado, com boas possibilidades para o emprego de práticas agrícolas mecanizadas. A vegetação é o recurso natural que melhor expressa a fisionomia da região. A variação fitofisionômica (campo limpo, campo sujo, cerrado e cerradão) caracteriza a heterogeneidade das condições ambientais, aspecto importante para a pesquisa agropecuária, principalmente no que se refere na possibilidade de extrapolação de dados experimentais de um local a outro (Goedert, 1989).

Os solos sob Cerrado, em sua maioria, apresentam propriedades que limitam o crescimento das raízes das plantas exigindo práticas de manejo adequadas. Trata-se de solos de baixa capacidade de troca de cátions (CTC), com acidez elevada e com baixo teor de nutrientes, especialmente de fósforo. São assim, solos com alto grau de intemperização e lixiviação, sendo que os problemas de acidez e deficiência de nutrientes ocorrem em todo perfil (Lopes, 1983; Adamoli, 1987; Goedert, 1989; Sousa \& Lobato, 2004). 
Desde o início da ocupação agrícola do Cerrado essa região vem apresentando desenvolvimento excepcional. Como exemplo, na safra 2001/2002 a produtividade média de milho nos Estados da Região Centro Oeste superou em 52\% a produtividade média brasileira de milho, atingindo um valor médio de $5.550 \mathrm{~kg} \mathrm{ha}^{-1}$ no Distrito Federal (Sousa \& Lobato, 2004).

No entanto já se começa a questionar os sistemas de manejo empregados, principalmente com relação aos conceitos de sustentabilidade, ou seja, de modo que os recursos naturais, notadamente solo e água, possam ser transferidos às gerações futuras em condições de capacidade produtiva. Assim, a ocupação humana do Cerrado nesses últimos anos acelerou os processos impactantes devido ao desmatamento de áreas nativas e grandes queimadas. Aliado a isso, a monocultura extensiva, que usa grande quantidade de insumo e máquinas agrícolas, vem alterando o equilíbrio ecológico e a qualidade física do solo.

\subsection{Produção de milho}

$\mathrm{O}$ milho é encontrado nos mais diversos ambientes, desde latitude $40^{\circ} \mathrm{S}$ até $58^{\circ}$ $\mathrm{N}$ e altitudes que variam entre $3.000 \mathrm{~m}$, nos Andes peruanos, até abaixo do nível do mar, em regiões do mar Cáspio, o que levou a uma grande especialização e adaptação da planta. Atualmente é cultivado em todas as regiões do mundo.

Estima-se que atualmente a produção mundial de milho seja em torno de 626.000 mil toneladas. Os Estados Unidos (EUA) são os maiores produtores mundiais com cerca de $45 \%$ da produção mundial total, apresentando também a maior área colhida e um dos maiores índices de produtividade média. Juntamente com China e Brasil, representam quase $70 \%$ do mercado mundial (FAO, 2004).

Com relação à produtividade média superior a $6.000 \mathrm{~kg} \mathrm{ha}^{-1}$, destacam-se além dos EUA, a Argentina, França, Itália, Canadá, Egito e Espanha, sendo este último o país com maior índice de produtividade média entre os 20 maiores produtores mundiais. É muito importante destacar a posição norte-americana, que, mesmo com cerca de 28 milhões de ha de área colhida, se situa como o país com $2^{\circ}$ índice de produtividade 
média entre os 20 maiores produtores mundiais, perdendo apenas da Espanha que apresenta somente 472 mil ha de área colhida (FAO, 2004).

O Brasil, apesar de ser o $3^{\circ}$ maior produtor mundial, ainda está longe de alcançar os índices adequados de produtividade, apresentando um índice muito baixo em relação a vários países (FAO, 2004). Este mesmo tipo de problema é encontrado em outros países de enormes áreas colhidas como México, Índia, Indonésia, África do Sul e Nigéria.

Hoje, o milho com uma área plantada de 12.706 .000 de ha é a segunda cultura mais cultivada no Brasil, estando abaixo apenas da soja com cerca de 21 milhões de hectares. A produtividade média brasileira é baixa, comparada a outros países produtores. Os estados de áreas superiores a 500 mil hectares com maiores índices de produtividade são em ordem decrescente, Goiás, Santa Catarina, Paraná, Minas Gerais, São Paulo, Mato Grosso, Mato Grosso do Sul e Rio Grande do Sul (Companhia Nacional de Abastecimento - Conab, 2004).

O milho sempre foi tradicionalmente utilizado como fonte energética animal e humana. Mais recentemente seu uso se ampliou para a produção de amido, álcool, adoçantes, óleo, etc; sendo que os Estados Unidos deverão absorver $23 \%$ da produção da safra 2003/04 para esse fim. Hoje também existem ótimas expectativas quanto ao uso de milho para a produção de biocombustíveis. Com isso, o consumo mundial de milho deverá crescer cerca de $22 \%$ nos próximos dez anos, impulsionado pela transformação do cereal em etanol e na utilização de óleos vegetais como combustível em diversos países.

Com relação aos principais países exportadores, observa-se que a quantidade exportada pelos Estados Unidos chega a $62,7 \%$ do total exportado por todos os países. Juntamente com China e Argentina detém quase $90 \%$ do volume total exportado. Estes números mostram uma grande oportunidade para o Brasil participar mais ativamente deste mercado, já que, China e Estados Unidos são países que não devem incrementar seus volumes de exportação. Destaca-se, portanto, a importância em se elevar a baixa produtividade brasileira (3.662 $\left.\mathrm{kg} \mathrm{ha}^{-1}\right)(\mathrm{FNP}, 2004)$. 
A produtividade das plantas é regulada por fatores genéticos e ambientais, que, quantitativamente, exercem peso semelhante no rendimento final. Dentre os fatores ambientais, a nutrição adequada, garantida por um programa balanceado de adubação e de calagem, é responsável por um incremento de cerca de 20 a $25 \%$ no rendimento.

\subsection{Pesquisa em escala de campo}

A pesquisa aplicada deve, por definição, fornecer informações úteis ao manejo das áreas no setor produtivo preferivelmente do que definir novos conceitos (Ikerd, 1993). Por isso é crescente o número de pesquisadores e produtores que estão envolvidos em pesquisa participativa, onde estes contribuem para programas de longa duração e assumem funções de liderança na identificação, localização e condução dos programas de pesquisa "on-farm" (Watkins, 1990; Rzewnicki, 1991; Gerber, 1992; Ikerd, 1993; Norman et al., 1998).

Alguns tipos de investigações ou metas de pesquisa requerem precisão somente por meio de experimentações controladas em escala de parcelas no campo. Outras metas de pesquisa são melhores processadas em experimentos "on-farm". Segundo Lockeretz (1987), as investigações conduzidas em fazendas incluem:

1. O mapeamento de tipos específicos de solo ou condições ambientais não conhecidas na estação experimental;

2. O estudo do manejo realizado na propriedade rural;

3. A análise de sistemas integrados de produção agropecuária;

4. A avaliação produtiva de um sistema de manejo sobre as reais condições da fazenda;

5. O exame de acontecimentos, requerendo com isto extensas áreas (por exemplo, erosão e infestação de pragas);

6. O estudo dos efeitos das práticas específicas de manejo por longo prazo;

7. A avaliação das inovações tecnológicas implantadas na fazenda.

Novas tecnologias usadas no manejo de áreas específicas incluem o Sistema de Posicionamento Global (GPS), o Sistema de Informações Geográficas (GIS) e o uso de 
sensores de avaliação direta, por exemplo, que são também melhor avaliados em escala de campo (Heuvel, 1996).

Embora as pesquisas "on-farm" ofereçam excitantes possibilidades de investigações, essas nem sempre utilizam conceitos estatísticos tradicionais de repetição e bloco. Repetição é definida como múltiplas unidades experimentais por tratamento na qual uma unidade experimental é a menor subdivisão do material experimental para o qual um tratamento é independentemente aplicado (Lentner \& Bishop, 1993). Bloco é o grupamento de unidades experimentais dentro de uma área homogênea onde tipicamente cada tratamento é aleatoriamente designado para não mais que uma unidade experimental no bloco.

Exemplos de experimentos de não repetição tomam várias formas. Múltiplas localizações de tratamentos identificados (Johnson et al., 1992; Moreau et al., 1999) são comumente usadas como repetições. Experimentos de séries temporais comparam mudanças nas unidades experimentais com aquelas de uma unidade de referência sobre o tempo (Hawkins, 1986; Stewart-Oaten et al., 1986). Comparações de antes e depois são usadas em estudos de impactos ambientais (Wiens \& Parker, 1995). Resultados de independência experimental múltipla são freqüentemente combinados para simular a repetição (Hannah, 1999). Outros pesquisadores usam testes preliminares ou separados para derivar uma estimativa do erro experimental que é aplicado em experimentos subseqüentes, fazendo o erro experimental derivado e a repetição não necessária (Box et al., 1978). Beyers (1998) sugeriu o uso de inferência casual apoiado por simples estatística descritiva incluindo tabelas, gráficos, estimativas de médias e erro padrão, regressão e análises multivariadas para avaliar resultados experimentais.

\subsection{Agricultura de Precisão}

Agricultura de Precisão é o termo dado para uma forma de gestão das culturas, no qual as áreas de produção são manejadas com a aplicação de diferentes doses de insumos (Godwin et al., 2003). Os dois principais benefícios da Agricultura de Precisão podem ser listados como: 
1. Aumento da margem econômica de lucro por incrementos na produção e/ou redução no custo de produção variável para a cultura;

2. Diminuir o risco de poluição ambiental por dimensionar racionalmente a aplicação dos insumos.

Esses benefícios são excelentes exemplos de onde considerações econômicas e ambientais são trabalhadas juntas (Godwin et al., 2003). Sendo que o objetivo fundamental da Agricultura de Precisão é o manejo da variação espacial nas culturas gerando benefícios econômicos e/ou ambientais (Taylor et al., 2003). Para se alcançar isso, os dois precursores vitais são:

1. Identificação confiável da variabilidade espacial;

2. Criteriosa interpretação para guiar as estratégias de manejo.

Crescentemente as investigações agronômicas estão explorando o uso de computadores e tecnologias de satélites aplicados como ferramentas em escala de campo, incluindo monitores georeferenciados de produtividade e os dados de sensoriamento remoto e direto. Estas tecnologias são apropriadas em uma infinidade de experimentações agronômicas focalizadas nos padrões espaciais para toda área de estudo. Como no resultado das pesquisas agronômicas atuais que estão diretamente relacionadas ao conhecimento da inter-relação espacial e temporal no meio físico, químico e biológico das propriedades do solo e suas contribuições combinadas para a produtividade das culturas em escala de campo (Johnson et al., 2003).

O reconhecimento dos limites espaciais com os equipamentos de registro da produção e controle da aplicação dos insumos agrícolas a taxas variáveis tem despertado o interesse de estudos em propriedades rurais. $O$ principal catalisador foi 0 direcionamento do Sistema de Posicionamento Global (GPS) e dos Sistemas de Informações Geográficas (GIS) para o uso civil (Godwin et al., 2003).

\subsection{Amostragem}

A interpretação ideal dos padrões espaciais é feita através do mapa gerado para um determinado atributo mostrando a magnitude da variável de interesse em todos os pontos da área. Contudo, a análise dos atributos de solo e planta em todos os pontos não 
é técnica e economicamente viável. Portanto, são necessárias observações estrategicamente localizadas ou representativas da área de estudo (Taylor et al., 2003).

Neste contexto a estratégia de amostragem deve auxiliar na elaboração suficientemente criteriosa da variabilidade das propriedades do solo a um custo economicamente viável. O número e a densidade das observações para diferentes níveis de exatidão a fim de representar uma superfície topográfica são relativamente fáceis de determinar. Entretanto esse não é o caso da maioria das variáveis do solo. Essas não são imediatamente visíveis e, portanto, fazem a amostragem se tornar mais difícil (Taylor et al., 2003).

A amostragem de solo para a avaliação da acidez e da fertilidade é uma prática comum nas fazendas para aplicações de corretivos e fertilizantes de maneira uniforme. Nos últimos anos, tem crescido o interesse e a utilização de amostragens de solo na forma sistemática para a aplicação de corretivos e fertilizantes a taxas variáveis. A analise química do solo é tipicamente conduzida por amostras obtidas pelo caminhamento em ziguezague no campo (Raij, 1991) ou por amostras individuais de solo tiradas em pontos numa malha (Earl et al., 2003). As investigações "on farm" são tipicamente conduzidas usando uma malha quadrada, espaçados de $100 \times 100 \mathrm{~m}$, ou seja, uma amostra de solo para cada hectare (Earl et al., 2003). No Brasil, as investigações conduzidas por empresas especializadas sugerem que uma amostra pode representar desde um até 20 hectares. Na amostragem em malha, a escolha da dimensão da malha afeta os custos de amostragem e a criteriosidade na representação da variável amostrada.

As medidas feitas a partir de amostras simples do solo podem conter um grande elemento de variação. A subamostragem para compor uma amostra composta é necessária para dar maior representatividade aos valores obtidos. O protocolo de amostragem para obter amostras representativas de todo um talhão sugere 0 caminhamento em ziguezague cruzando o campo e retirando amostras simples em intervalos regulares seguindo o caminhamento. Essas são misturadas retirando-se uma amostra composta sendo obtido já no campo um valor médio (Raij, 1991). 


\subsection{Estatística Clássica}

A estatística não espacial, freqüentemente referida com estatística clássica, também é usada para examinar aspectos da variabilidade dos atributos do solo. A base teórica e o detalhamento dos métodos estatísticos clássicos são amplamente descritos em Spiegel (1985), Gomes (1987a), Gomes (1987b), Banzato \& Kronka (1995); Levine et al. (2000). Outros autores discutem diretamente a aplicação destes conhecimentos ao estudo da variabilidade dos solos (Warrick \& Nielsen, 1980; Reichardt et al., 1986; Souza, 1992; Mulla \& McBratney, 2000).

Os parâmetros estatísticos considerados pela estatística clássica são a média, a moda, a mediana, o desvio padrão da média, a variância, a distribuição de frequiência dos dados, o coeficiente de variação, o coeficiente assimetria, o coeficiente curtose e o intervalo de confiança para os resultados.

A estatística clássica baseia-se na pressuposição que a variável estudada apresenta distribuição aleatória no campo. A variável estudada pode assim ser representada por um valor médio com um intervalo de confiança. Conforme Trangmar et al. (1985), a estatística clássica assume, além da homogeneidade a aleatoriedade dos dados, que o valor esperado de uma propriedade do solo $(\mathrm{Z})$ em um determinado ponto $(\mathrm{x})$ na área estudada é dependente do valor central, eq. (1):

$$
\mathbf{Z}(\mathbf{x})=\boldsymbol{\mu}+\boldsymbol{\varepsilon}(\mathbf{x})
$$

onde $\mathbf{Z}(\mathbf{x})$ é o valor esperado em qualquer ponto da área experimental e $\boldsymbol{\varepsilon}(\mathbf{x})$ representa a variação em torno da média.

Além da média, existem outras medidas de tendência central. A mediana, por exemplo, é o valor que divide a distribuição em duas partes iguais, é o centro da distribuição. Uma primeira análise dos dados para verificação da normalidade pode ser feita quando comparados os valores das duas mediadas de posição. A proximidade dos dois valores é uma indicação de uma distribuição simétrica.

O conhecimento da distribuição de freqüência dos dados de uma variável direciona a escolha do parâmetro estatístico mais apropriado. Assim, a média aritmética é uma boa medida descritiva para dados com distribuição normal. No entanto, para a 
distribuição lognormal, deve-se utilizar a mediana, que se caracteriza por ser uma medida não significativamente afetada por valores extremos (Souza, 1992; Oliveira et al., 1999).

Para verificação da variabilidade dos dados em torno do valor médio e a precisão deste valor como bom estimador de pontos não amostrados, alguns parâmetros estatísticos são utilizados. As medidas mais freqüientes utilizadas são: amplitude total $(R)$, amplitude interquartílica (Ai), desvio padrão (s) e coeficiente de variação (CV).

A amplitude total é um parâmetro que deve ser utilizado na comparação de conjuntos de dados, quando estes apresentam distribuições simétricas, visto ser um parâmetro pouco resistente a valores discrepantes. Segundo Goes (1980) e Hoaglin et al. (1983), em casos cuja assimetria seja verificada, a utilização da amplitude interquartílica é mais indicada.

A amplitude total dos dados (R) pode ser calculada segundo a eq. (2):

$$
\mathbf{R}=\left(\mathbf{z}_{\text {máximo }}-\mathbf{z}_{\text {mínimo }}\right)
$$

onde $\mathbf{z}_{\text {mínimo }}$ é o menor valor encontrado para a variável estudada e $\mathbf{z}_{\text {máximo }}$ é o maior valor.

A amplitude interquartílica pode ser calculada segundo a eq. (3):

$$
\mathbf{A} \mathbf{i}=(\mathbf{Q} s-\mathbf{Q} \mathbf{i})
$$

onde Qs é o quartil superior ou o terceiro quartil e Qi é o quartil inferior ou primeiro quartil.

A amplitude interquartílica também pode ser utilizada como limite crítico da distribuição, auxiliando na retirada de dados perturbadores denominados de "outliers". Cahn et al. (1994) empregou o desvio padrão multiplicado por quatro como limite para retirada de dados, utilizando com decisão os coeficientes de assimetria e curtose. Neste trabalho os autores retiraram no máximo 1,5\% do total amostral, quando, dentro do critério utilizado, apresentavam assimetria e curtoses elevadas.

O desvio padrão (s) é definido segundo a eq. (4): 


$$
s=\left[\sum \frac{\left(z_{i}-z_{m}\right)^{2}}{(n-1)}\right]^{1 / 2}
$$

onde $\mathbf{z}_{\mathbf{i}}$ é o valor individual da variável $\mathbf{Z}, \mathbf{z}_{\mathbf{m}}$ é a média aritmética da variável e (n-1) o número de graus de liberdade.

O coeficiente de variação é uma medida adimensional da dispersão dos resultados (Carvalho et al., 2003). Permite, portanto, comparar duas ou mais variáveis independentemente das suas unidades. $O$ coeficiente de variação pode ser calculado pela eq. (5):

$$
C V(\%)=100\left(\frac{s}{z_{m}}\right)
$$

onde $\mathbf{z}_{\mathbf{m}}$ é a média aritmética dos dados e s o desvio padrão.

Esse parâmetro foi utilizado como medida de variabilidade e serviu de base para os estudos de Warrick \& Nielsen (1980). Estes autores, estudando a variabilidade de diversas propriedades do solo, verificaram que, para algumas, a variabilidade expressa pelo coeficiente de variação pode ser inferior a $10 \%$, enquanto para outras pode superar $1000 \%$. Classificaram a variabilidade em três níveis: baixa (abaixo de 12\%), média (entre 12 e $80 \%$ ) e alta (acima de $80 \%$ ).

Segundo Trangmar et al. (1985), propriedades do solo muito afetadas pelo manejo apresentam maior variabilidade do que aquelas relacionadas às características morfológicas do solo (cor e horizontes), físicas (tamanho das partículas e densidade das partículas), e químicas $(\mathrm{pH})$. Oliveira (1973), estudando as características de um Latossolo Roxo e um Latossolo Vermelho Escuro-Orto, verificou que as características físicas e morfológicas do solo apresentam maior homogeneidade que as químicas. Esse autor encontrou, para o conteúdo de argila e as medidas de $\mathrm{pH}$, coeficientes de variação inferiores a $10 \%$. Por outro lado, para os teores de cálcio, magnésio, potássio e soma de bases, os coeficientes foram acima de 40\%. Resultados semelhantes foram encontrados por Paz et al. (1996), em que os 
parâmetros físico-químicos apresentaram menor variabilidade que os macros e micronutrientes do solo.

Segundo Gonçalves (1997), a hipótese de normalidade é assumida freqüentemente, pois é a base para o desenvolvimento de muitos métodos estatísticos. Por outro lado, estudos vêm demonstrando que, além da distribuição normal, algumas variáveis têm apresentado distribuição assimétrica e ajuste à distribuição log-normal.

Muitos métodos são utilizados para a verificação da normalidade de uma distribuição. Essa verificação pode ser feita utilizando-se gráficos de distribuição de freqüências (Dourado Neto, 1989), gráficos de probabilidade normal (Nielsen et al., 1973; Moraes et al., 1993; Libardi et al., 1996), "Box-plot" (Libardi et al., 1996) ou dispositivo de ramos e folhas (Libardi et al., 1996; García y García, 1997). Pode também ser verificada utilizando a estatística não-paramétrica, como testes de aderência (qui-quadrado $\chi^{2}$ ) e o de Kolmogorov-Smirnov, apresentados por Campos (1983). Pode ser verificada ainda pelo método dos momentos, que avalia a dispersão dos dados e o formato da distribuição.

Segundo Landim (1988), o desenvolvimento das medidas de momentos para a descrição de uma distribuição teve como objetivo um procedimento que resultasse em estatísticas que descrevessem a distribuição com consistência, eficiência e suficiência; que pudessem testar a sua significância assegurando que os resultados não fossem aplicados a qualquer distribuição de freqüência independente do caráter das medidas.

Conforme Beiguelman (1994), o primeiro momento centrado na média $\left(\mathrm{m}_{1}\right)$ é nulo, pois sabe-se que $\Sigma\left(\mathbf{z}_{\mathbf{i}}-\overline{\mathbf{z}}\right)=\mathbf{0}$; o segundo momento centrado na média $\left(\mathrm{m}_{2}\right)$ é a variância, conforme eq. (6). Esse momento difere da variância amostral apenas pelo fato de apresentar no denominador, $n$, ao invés de $n-1$; o terceiro momento centrado na média $\left(m_{3}\right)$ é utilizado nos cálculos do coeficiente de assimetria (eq. 7); o quarto momento centrado na média $\left(\mathrm{m}_{4}\right)$ é utilizado na quantificação da curtose (eq. 8):

$$
\mathbf{m}_{2}=\frac{1}{\mathbf{n}} \sum_{\mathbf{i}=1}^{\mathbf{n}}\left(\mathrm{z}_{\mathbf{i}}-\overline{\mathbf{z}}\right)^{2}
$$




$$
\begin{aligned}
& m_{3}=\frac{1}{n} \sum_{i=1}^{n}\left(z_{i}-\bar{z}\right)^{3} \\
& m_{4}=\frac{1}{n} \sum_{i=1}^{n}\left(z_{i}-\bar{z}\right)^{4}
\end{aligned}
$$

A verificação da assimetria é feita em função dos valores de $g_{1}$ e a curtose por $g_{2}$, parâmetros que são calculados, respectivamente, pelas eq. (9) e (10), a seguir apresentadas (Beiguelman, 1994):

$$
\begin{aligned}
& g_{1}=\frac{m_{3}}{\sqrt{m_{2}{ }^{3}}} \\
& g_{2}=\frac{m_{4}}{\left(m_{2}\right)^{2}}
\end{aligned}
$$

A distribuição normal será verificada se o valor da assimetria $\left(g_{1}\right)$ for próximo de zero e o valor da curtose $\left(\mathrm{g}_{2}\right)$ for próximo de 3 . Com relação ao valor da curtose, pode ser definida, também, como $\left(\mathrm{g}_{2}-3\right)$, apresentando valores positivos e negativos como apresentado por Moraes (1991).

Quando a assimetria é nula os valores da média e mediana são iguais e a distribuição é simétrica. Quando os valores de assimetria são negativos, diz-se assimetria negativa, sendo a média menor que a mediana. No caso de valores de assimetria positivos, diz-se assimetria positiva, sendo a média maior que a mediana. Caso seja confirmada a simetria da distribuição, a normalidade será assumida, se o valor para curtose estiver dentro do admissível (Goes, 1980). Existem distribuições nas quais as médias são iguais, bem como as variabilidades, porém que podem diferir no seu achatamento ou curtose. Desse modo, as distribuições podem ser classificadas como leptocúrtica, mesocúrtica e platicúrtica, quando os valores de $\mathrm{g}_{2}$ forem, respectivamente, $\mathrm{g}_{2}=3, \mathrm{~g}_{2}>3$ e $\mathrm{g}_{2}<3$ (Spiegel, 1985). 
A utilização da assimetria e curtose em trabalhos de variabilidade espacial é bem difundida. Existem tabelas com os limites de aceitabilidade para os valores de assimetria e curtose com nível de significância, como a tabela de Jones (1969). Essa tabela foi utilizada por Salviano (1996) e Guimarães (1993) no processo de análise exploratória dos dados. Porém, alguns pesquisadores preferem fixar um valor de aceitabilidade para assimetria, como Paz et al. (1996), que aceitaram a hipótese de normalidade quando os valores de assimetria distanciaram-se de zero até no máximo um. 


\section{VARIABILIDADE DA FERTILIDADE DO SOLO DE UM TALHÃO MANEJADO HOMOGENEAMENTE}

\section{Resumo}

O conhecimento da variabilidade da fertilidade do solo em áreas cultivadas pode trazer importantes subsídios na racionalização de uso dos corretivos e fertilizantes do solo. O objetivo deste estudo de caso foi determinar a variabilidade da fertilidade do solo por meio do fracionamento de um talhão comercial em pequenas células de manejo. $O$ estudo de caso foi conduzido na Fazenda Alto Alegre em Planaltina - GO, numa área de 373 hectares de um Latossolo cultivada com milho na safra 2003/04. Traçado um polígono da área procedeu-se divisão em 80 células de manejo de quatro hectares cada. A amostragem do solo seguiu uma diagonal com doze pontos para compor a amostra composta representativa dentro de cada célula. As coordenadas desses pontos foram obtidas e arquivadas. Realizou-se a análise da textura do solo e da fertilidade completa do solo. A produtividade para cada célula foi obtida por meio da colhedora equipada com Sistema de Posicionamento Geográfico (GPS) e monitor de rendimento de grãos. $\mathrm{Na}$ análise da variabilidade dos dados foram considerados parâmetros estatísticos descritivos. A análise de regressão linear simples dos dados da fertilidade com a produtividade do milho foi realizada. A variabilidade foi considerada alta para o fósforo disponível, cobre e zinco; média para matéria orgânica (MO), enxofre, cálcio, magnésio, acidez potencial, soma de bases, capacidade potencial de troca de cátions, saturação por bases, boro, ferro e manganês e baixa para pH e potássio. Os coeficientes de correlação linear foram significativos e positivos para a matéria orgânica e boro versus produtividade do milho. Contudo, para cobre, manganês e zinco foram significativos e 
negativos. Em estudos de escala de campo normalmente não é possível isolar ou medir todos os fatores bióticos e abióticos que influenciam na produção da cultura. Entretanto, verificou-se que o conhecimento da variabilidade da fertilidade e produtividade pode fornecer importantes subsídios na racionalização do uso de insumos.

\section{SOIL FERTILITY VARIABILITY IN AN HOMOGENEOUSLY MANAGED CORN FIELD}

\section{Summary}

The acquaintance on the soil fertility variability in cultivated areas may bring important subsidies for rationalizing the use of fertilizers and soil amenders. The objective of this case study was to determine the soil fertility variability through the fractionation of a commercially grown corn field into small management cells. The study was carried out in Alto Alegre farm in Planaltina, GO, Brazil, in a Typic Dystrarox soil under cerrado (savannah) in an area with 373 ha of corn crop grown during 2003/4 period. After outlining a polygon of area it was divided into 80 management cells of 4 ha each. The soil sampling followed a diagonal with twelve points to constitute a representative composite sample within each cell. The co-ordinates of these points were obtained and recorded. The soil samples were analyzed for texture and soil fertility. The yield for each cell was obtained with a harvester equipped with GPS and grain yield monitor. For data variability analysis the descriptive statistic parameters were considered. The simple linear regression analysis of soil fertility versus corn grain yield data was applied. The variability was considered high for available phosphorus, copper and zinc contents; medium for soil organic matter, sulphur, calcium, and magnesium content, potential acidity, sum of bases, CEC, base saturation, boron, iron and manganese content and low for soil $\mathrm{pH}$ and potassium content. The linear correlation coefficients (LCC) were significants and positives for soil organic matter and boron content versus corn yield. However, the LCC for copper, manganese and zinc content were significants and negatives. Although it is not possible to isolate or measure 
all the biotic and abiotic factors affecting the yield in field scale study, the knowledge on soil fertility variability and grain productivity may provide important subsidies for rationalizing the farm input use.

\subsection{Introdução}

Numa paisagem natural o solo apresenta ampla variabilidade dos seus atributos tanto no sentido espacial como no temporal, resultante da interação de processos que comandam os fatores responsáveis por sua formação. Além disso, o solo cultivado revela fontes adicionais de heterogeneidade originadas exclusivamente pelo efeito antrópico da agricultura (Carvalho et al., 2003).

Souza (1992) relatou que inúmeros trabalhos têm mostrado que os sistemas de manejo conservacionistas criam um ambiente no solo diferente do encontrado no sistema convencional, resultante dos efeitos dos resíduos superficiais e do reduzido revolvimento do solo. Como resultado tem sido encontrado um acúmulo superficial de fertilizantes nos sistemas conservacionistas (Silveira et al., 2000). A maior amplitude dos atributos do solo no plantio direto explica muito bem os maiores coeficientes de variação (CV) desses atributos nesta prática de manejo em relação às demais. Em razão do não revolvimento do solo, como ocorre no plantio direto, espera-se maior variabilidade nos dados. Segundo Souza (1992), o sistema convencional usando grade aradora apresenta menor variabilidade nos teores de matéria orgânica e no dos nutrientes da camada arada do solo em comparação com a escarificação e o plantio direto.

Existe certa heterogeneidade dos atributos químicos e físicos de um solo, mesmo em uma área considerada uniforme segundo suas características visíveis de campo como topografia, cor do solo e vegetação. Para que a amostragem do solo represente com exatidão a sua fertilidade é necessário o conhecimento dessa variabilidade, pois só assim as recomendações de calagem e adubação não estariam comprometidas (Silveira et al., 2000).

Segundo Carvalho et al. (2003) a variabilidade espacial nos atributos do solo pode ser influenciada pelos seus fatores intrínsecos (fatores de formação, que são o material de origem, relevo, clima, organismos e tempo) e pelos fatores extrínsecos 
normalmente relacionados ás práticas de manejo. Usualmente uma forte dependência espacial nos atributos do solo é atribuída aos fatores intrínsecos (Cambardella et al., 1994).

Como o conhecimento da variabilidade dos atributos de fertilidade do solo associando à produtividade da cultura, pode auxiliar na racionalização e maior eficiência de uso dos fertilizantes e corretivos, e diminuição do risco ambiental pela contaminação dos recursos hídricos, objetivou-se, a partir de um estudo de caso, verificar a variabilidade dos atributos de fertilidade do solo, por meio do fracionamento de um talhão comercial em pequenas células de manejo.

\subsection{Material e Métodos}

\subsubsection{Caracterização geral da área de estudo}

De 1987 a 1989, a área que estava sob vegetação natural de cerrado foi desmatada para o cultivo da soja. Após 1994, a área passou a ser cultivada em semeadura direta com a utilização do milho, além da soja. O estudo de caso foi conduzido na Fazenda Alto Alegre localizada no município de Planaltina - GO, numa área de 373 hectares, cultivada com milho sequeiro na safra 2003/04. O solo da área foi classificado como Latossolo Vermelho-Amarelo.

A definição dos pontos e procedimento de amostragem do solo é descrita a seguir. O GPS Etrex Vista ${ }^{\circledR}$ foi utilizado para traçar uma poligonal da área. De posse do polígono procedeu-se divisão da área em 80 células de manejo de quatro hectares cada. As células dos limites da bordadura foram desconsideradas para fins de amostragem. A amostragem seguiu uma diagonal com doze pontos para compor a amostra representativa, dentro de cada uma dos 80 células. As coordenadas desses pontos foram obtidas e arquivadas.

\subsubsection{Análise química e física do solo}

A amostragem do solo foi realizada na profundidade de $0-20 \mathrm{~cm}$ com uma sonda com diâmetro de $2 \mathrm{~cm}$, antes da semeadura do milho. As amostras de solo foram secas ao ar, passadas em peneiras com malha de $2 \mathrm{~mm}$ e analisadas quimicamente (rotina) em 
relação a pH em água, $\mathrm{pH}$ em $\mathrm{CaCl}_{2} 0,01 \mathrm{~mol} \mathrm{~L}^{-1}$, acidez total $(\mathrm{H}+\mathrm{Al})$ com solução de acetato de cálcio, matéria orgânica (MO) pelo método espectrofotométrico (Raij et al., 2001).

As determinações dos macronutrientes fósforo $(\mathrm{P})$, cálcio $(\mathrm{Ca})$, magnésio $(\mathrm{Mg})$ e potássio $(\mathrm{K})$, foram realizadas utilizando a Resina como extrator e de acordo com metodologia descrita em Raij et al.(2001). As determinações dos micronutrientes cobre $(\mathrm{Cu})$, manganês $(\mathrm{Mn})$, zinco $(\mathrm{Zn})$ e ferro $(\mathrm{Fe})$ foram realizadas usando como solução extratora o DTPA a pH 7,3 (Lindsay \& Norvell, 1978). O enxofre ( ${\mathrm{S}-\mathrm{SO}_{4}}^{2-}$ ) e o boro $\left(\mathrm{H}_{3} \mathrm{BO}_{3}\right)$ no solo foram determinados pelo método do Fosfato Monobásico de Cálcio e extração em água quente, respectivamente (Raij et al., 2001).

De posse dos resultados da análise do solo, foram calculados os seguintes parâmetros de fertilidade: soma de bases (SB), capacidade de troca de cátions a pH 7,0 (T) e saturação por bases (V). A análise granulométrica do solo, para o conteúdo de areia, silte e argila, foi realizada utilizando-se o método do densímetro (EMBRAPA, 1997).

\subsubsection{Obtenção dos dados de produtividade}

Os dados de produtividade do talhão foram obtidos no momento da colheita do milho, por meio de colhedora New Holland TC 59 equipada com Sistema de Posicionamento Geográfico (GPS), sensor de fluxo de grãos por placa de impacto, sensor de umidade de grãos, sensor de velocidade de deslocamento da colhedora e sensor de controle de altura da plataforma. Essas informações foram gerenciadas pelo monitor de rendimento de grãos AgLEADER PFAdvantage ${ }^{\circledR}$, que fez as leituras de produtividade, altitude e umidade de grãos a cada dois segundos, durante a colheita da cultura em toda a área.

O Sistema de Informação Geográfica (SIG) ArcView foi utilizado para a visualização dos dados brutos de produtividade de grãos e altitude. A partir desses dados pode-se fazer a interpolação, pelo método do inverso do quadrado da distância

A obtenção dos dados médios de produtividade e altitude, para cada uma das 80 células de manejo, foi realizado pelo SIG. Foram sobrepostos os pontos 
georeferenciados das subamostras do solo e os mapas de dados brutos de produtividade e altitude. Em cada ponto de subamostra, foram selecionados os dados de produtividade e altitude, contidos em um círculo com $10 \mathrm{~m}$ de raio, criado pelo programa utilizando-se a ferramenta "Select Feature". Esses dados selecionados serviram para obter os dados médios de cada uma das 80 células de manejo.

\subsubsection{Análise estatística}

$\mathrm{Na}$ análise estatística dos resultados, foi considerado o cálculo dos parâmetros estatísticos referentes às medidas de tendência central e variabilidade, para cada conjunto de valores. Foram calculados os coeficientes de assimetria e curtose, para se inferir sobre o tipo e o formato da curva de distribuição dos resultados de cada atributo do solo. Os resultados da análise estatística descritiva foram apresentados também, na forma de histogramas de freqüências, retas de probabilidade normal e gráficos de "Boxplot". O histograma de freqüências, trás como complemento o resultado do teste nãoparamétrico de Kolmogorov-Smirnov, com o objetivo de verificar a normalidade da

distribuição. A análise de regressão linear simples foi realizada para analisar uma possível relação direta entre os atributos do solo e os dados médios de produtividade do milho e altitude da área, em cada célula de manejo, ao nível de $5 \%$ de probabilidade.

\subsection{Resultados e Discussão}

\subsubsection{Textura}

$\mathrm{Na}$ tabela 1 estão apresentados os parâmetros estatísticos descritivos para os teores de areia, silte e argila do solo, determinados pelo método do densímetro (EMBRAPA, 1997). 
Tabela 1. Parâmetros estatísticos descritivos para a análise textural na camada de 0 a $20 \mathrm{~cm}$, em Latossolo sob rotação soja/milho

\begin{tabular}{lccc}
\hline \multicolumn{1}{c}{ Parâmetros Avaliados } & Areia & Silte & Argila \\
\hline № de amostras & 80 & 80 & 80 \\
Média & 134,6 & 208,9 & 656,5 \\
Mediana & 120,0 & 190,0 & 685,0 \\
Mínimo & 60,0 & 120,0 & 380,0 \\
Máximo & 360,0 & 450,0 & 790,0 \\
Quartil inferior & 90,0 & 180,0 & 615,0 \\
Quartil superior & 150,0 & 220,0 & 720,0 \\
Amplitude & 300,0 & 330,0 & 410,0 \\
Variância & 4518,8 & 2546,8 & 9516,7 \\
Desvio Padrão & 67,2 & 50,5 & 97,6 \\
CV (\%) & 49,9 & 24,2 & 14,9 \\
Assimetria & 1,7 & 1,9 & $-1,4$ \\
Curtose & 2,4 & 5,5 & 1,4 \\
\hline
\end{tabular}

\subsubsection{Areia}

A média e mediana, para o conteúdo de areia, são diferentes entre si, portanto a curva de distribuição não tende à normal. Os coeficientes de assimetria e de curtose dos atributos são apresentados para efeito de comparação com a distribuição normal (Salviano el at., 1998). O coeficiente de assimetria mostra que essa distribuição é fortemente assimétrica. Como o coeficiente é positivo trata-se de uma distribuição assimétrica à direita. Pode-se também dizer que a curva de distribuição é do tipo leptocúrtica, devido ao valor diferente de zero e positivo, para o coeficiente de curtose.

A alta variabilidade do conteúdo de areia foi inferida pelo elevado $\mathrm{CV}$ da ordem de 49,9\%. Segundo a classificação de Warrick \& Nielsen (1980), porém, este valor está contido dentro da classe de média variabilidade, definida por esses autores. Não é surpresa esta alta variabilidade dos resultados, pois a área de estudo possui uma grande 
superfície, de relevo suave ondulado, ocorrendo variações de textura e, possivelmente, do tipo de solo. Pode-se notar que a dispersão dos valores de areia é também elevada, devido aos altos valores das medidas estatísticas de variação. Outra consideração diz respeito à amplitude do conteúdo de areia, obtida a partir dos valores mínimo e máximo de 60 e $360 \mathrm{~g} \mathrm{~kg}^{-1}$, respectivamente. No entanto, a amplitude total deve ser vista com muita reserva, já que esta medida leva em consideração apenas os dois valores extremos de um conjunto, sendo, muitas vezes, afetada por um valor particularmente discrepante (Salviano, et al., 1998).

Pela Figura 1 pode-se visualizar o histograma de freqüência, a reta de probabilidade normal e o gráfico de "Box-plot", para o conteúdo de areia. O histograma mostra a forte assimetria à direita. Existe uma grande flutuação dos pontos em relação à reta de probabilidade normal, demonstrando que a distribuição dos conteúdos de areia esta distante da normalidade. Pelo gráfico de "Box-plot" observa-se, como no histograma, a forte assimetria na distribuição dos resultados. Pode-se verificar que a faixa representando $50 \%$ dos valores ao redor da média, é bastante estreita. Tem-se uma grande dispersão dos conteúdos de areia acima do valor correspondente ao quartil superior.

\subsubsection{Silte}

A diferença que existe, para o conteúdo de silte, entre a média e mediana, indica que os valores de silte no solo não seguem uma distribuição normal. $O$ alto valor calculado para o coeficiente de assimetria, mostra que a curva distribuição dos conteúdos da variável possui uma forte assimetria, e pelo fato deste coeficiente ser positivo, pode-se inferir que a assimetria é positiva. $O$ coeficiente de curtose para o conjunto dos resultados de silte foi o de maior grandeza dentre os componentes granulométricos determinados, indicando um formato leptocúrtico para a curva de distribuição.

Com o CV da ordem de $24,2 \%$, pode-se considerar que os conteúdos de silte apresentaram média variabilidade, segundo o critério definido por Warrick \& Nielsen 
(1980). Os valores de variância, desvio padrão e amplitude são elevados e, portanto, a variável apresentou uma dispersão própria na área do estudo.

Na Figura 1 está apresentado o histograma, a reta de probabilidade normal e o gráfico de "Box-plot", para os resultados do conteúdo de silte das amostras coletadas na área de estudo. A forte assimetria à direita do valor médio para o conjunto de valores de silte, e que foi presumida pela análise descritiva dos resultados, é visualizada por meio do histograma de frequiências. Nota-se a falta de ajuste dos pontos em relação à reta de probabilidade normal e também a presença de um valor que é forte candidato a "outlier", na extremidade superior da reta. Porém, fica difícil presumir algum erro analítico, devido ao fato deste componente textural ser obtido por simples subtração entre os outros dois componentes, que são determinados de maneira direta e não indireta. $O$ gráfico de "Box-plot" serve para visualizar de forma mais clara a forte assimetria à direita (Figura 1). O valor da mediana está deslocado do centro da caixa onde concentra $50 \%$ dos resultados de silte ao redor do conteúdo médio desta variável. Esses valores de silte são representados por uma faixa muito estreita, bem mais do que em relação ao ocorrido para o conteúdo de areia.

\subsubsection{Argila}

A média e mediana, para o conjunto de resultados de argila, possuem uma diferença elevada, comparativamente a diferença entre estas duas medidas de tendência central para os outros dois componentes granulométricos do solo. A distribuição deste conjunto não segue, portanto, uma distribuição normal sendo assimétrica à esquerda, devido ao coeficiente de assimetria ter apresentado sinal negativo. Da mesma forma que ocorreu com os conteúdos de areia e silte, a argila apresentou uma curva de distribuição do tipo leptocúrtica, a partir da interpretação do coeficiente de curtose (Tabela 1).

O CV foi da ordem de $14,9 \%$, indicando que a variabilidade dos teores de argila no solo é menor que a variabilidade em comparação com os outros componentes da análise textural. Dessa forma, neste estudo, os conteúdos de areia possuem a maior variabilidade, seguidos pelos de silte e, por fim, os de argila, com a menor variabilidade. Porém, para Warrick \& Nielsen (1980), estes atributos físicos do solo apresentaram 
média variabilidade. A dispersão dos conteúdos de argila em torno do valor médio é mais elevada em comparação com a areia e silte. Esta informação é justificada pela elevada variância e desvio padrão para os resultados de argila no solo. É maior também a diferença entre o valor mínimo e máximo de argila, em comparação com a diferença entre estes dois valores no caso do conteúdo de areia e silte.

O histograma de frequiências, a reta de probabilidade normal e o gráfico de "Boxplot" dos conteúdos de argila estão apresentados na Figura 1. No histograma, pode-se ver a forte assimetria negativa dos valores de argila. Isto era esperado, pois sendo esta classe textural inversamente proporcional a classe areia, observa-se a complementaridade entre estas duas variáveis. Isto pode ser observado também por meio das retas de probabilidade normal para as duas variáveis, verificando que a flutuação dos pontos em relação à reta ocorre em direções opostas nos dois casos. O gráfico de "Boxplot" é mais uma confirmação da distribuição assimétrica dos conteúdos de argila. Com o valor da mediana não coincidindo com o centro da caixa, como ocorre para o gráfico referente ao conteúdo de silte, porém com este deslocamento em direções opostas. Notase que a faixa de conteúdo de argila que envolve $50 \%$ dos valores determinados pela análise textural do solo, delimitada pelo quartil inferior e superior, é maior para esta variável, do que para areia e silte. A dispersão dos teores de argila é observada em maior grau, para os valores abaixo do quartil inferior, ao contrário do que ocorre com os dois outros conjuntos.

Pode-se inferir que a variabilidade para os conteúdos de areia, silte e argila foi devida a uma fonte intrínseca representada pelos fatores de formação do solo. Variabilidade intrínseca é causada pela variação natural do solo, e a variabilidade extrínseca é gerada no campo por meio das práticas de manejo da produção agrícola (Cambardella, et al., 1994; Carvalho et al., 2003). Estes mesmos autores comentam que propriedades com forte dependência espacial podem ser controladas por variações intrínsecas nas características do solo, como a textura e a mineralogia. 

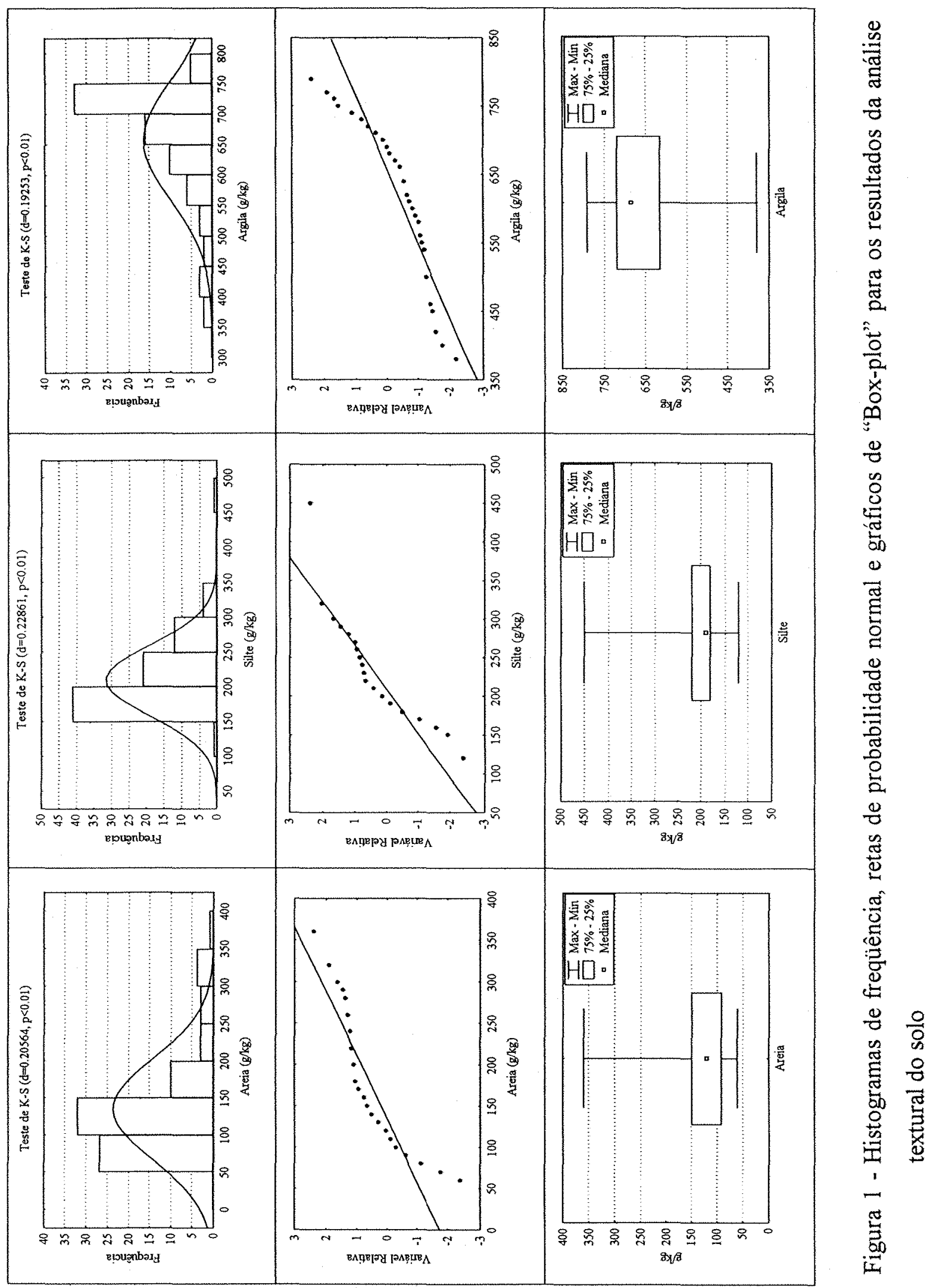


\subsubsection{Acidez do solo}

$\mathrm{Na}$ tabela 2 estão apresentados os parâmetros estatísticos descritivos para o $\mathrm{pH}$ em água, $\mathrm{pH}$ em $\mathrm{CaCl}_{2} \mathrm{e} \mathrm{H}+\mathrm{Al}$ no solo, que serão discutidos na seqüência.

Tabela 2. Parâmetros estatísticos descritivos da acidez ativa e acidez potencial $(\mathrm{H}+\mathrm{Al})$, na camada de 0 a $20 \mathrm{~cm}$, em Latossolo sob rotação soja/milho

\begin{tabular}{lccc}
\multicolumn{1}{c}{ Parâmetros Avaliados } & $\mathrm{pH}_{\text {água }}$ & $\mathrm{pH} \mathrm{CaCl}$ & $\mathrm{H}+\mathrm{Al}$ \\
\hline No de amostras & 80 & 80 & $\mathrm{mmol}_{\mathrm{c}} \mathrm{kg}^{-1}$ \\
Média & 5,43 & 4,83 & 80 \\
Mediana & 5,40 & 4,80 & 54,06 \\
Mínimo & 5,10 & 4,50 & 54,00 \\
Máximo & 5,90 & 5,40 & 30,00 \\
Quartil inferior & 5,30 & 4,70 & 78,00 \\
Quartil superior & 5,50 & 4,90 & 48,00 \\
Amplitude & 0,80 & 0,90 & 63,00 \\
Variância & 0,03 & 0,03 & 48,00 \\
Desvio Padrão & 0,17 & 0,17 & 122,46 \\
CV(\%) & 3,08 & 3,54 & 20,47 \\
Assimetria & 0,28 & 0,70 & $-0,27$ \\
Curtose & 0,12 & 0,96 & $-0,51$ \\
\hline
\end{tabular}

\subsubsection{Acidez ativa}

$\mathrm{O} \mathrm{pH}$ é provavelmente a característica química mais simples e importante de um solo. McBride (1994) diz que o pH é a "variável mestre", e o conhecimento do pH é necessário para entender importantes processos químicos, a disponibilidade de nutrientes para as plantas e a resposta negativa de algumas espécies de plantas à correção de solos ácidos. $\mathrm{O} \mathrm{pH}$ em cloreto de cálcio é uma determinação mais precisa do que o $\mathrm{pH}$ determinado em água, bastante afetado por pequenas quantidades de sais presentes no solo (Schofield \& Taylor, 1955; Davey \& Conyers, 1988). Como existem na literatura 
muitos dados disponíveis com valores de $\mathrm{pH}$ determinados em água é, portanto, importante conhecer a relação entre o pH determinado em água e em $\mathrm{CaCl}_{2}$ (Raij, 1991).

A média e mediana foram praticamente iguais, para $\mathrm{pH}$ em água e $\mathrm{CaCl}_{2}$ a 0,01 mol L $\mathrm{L}^{-1}$, demonstrando que a acidez ativa do solo possui uma distribuição que tende a normal. $\mathrm{O}$ coeficiente de assimetria para a distribuição de $\mathrm{pH}$ indica uma certa simetria, mais perfeita para a determinação em água, pois o valor está mais próximo de zero. $O$ coeficiente de curtose, também próximo a zero, mostra que a curva de distribuição apresenta a forma mesocurtica. Nota-se que este parâmetro estatístico está mais próximo de zero para o $\mathrm{pH}$ em água do que para o $\mathrm{pH}$ em $\mathrm{CaCl}_{2}$.

O CV calculado para o pH foi considerado baixo, tanto na determinação em água $(3,1 \%)$, quanto em $\mathrm{CaCl}_{2}(3,5 \%)$, segundo o critério proposto por Warrick \& Nielsen (1980). Este resultado concorda com os obtidos por diversos trabalhos (Souza, 1992; Souza et al., 1997; Carvalho et al., 1998; Salviano et al., 1998; Oliveira et al., 1999; Silveira et al., 2000; Carvalho et al., 2003). As medidas estatísticas de variabilidade foram idênticas nos dois conjuntos de $\mathrm{pH}$ mostrando que a dispersão dos resultados em torno de um valor médio foi igual.

$\mathrm{Na}$ Figura 2 encontram-se as representações gráficas das distribuições de freqüência, as retas de probabilidade normal e os gráficos de "Box-plot", para as determinações de $\mathrm{pH}$ em água e em $\mathrm{CaCl}_{2}$. Observa-se pelos histogramas que as curvas de distribuição de freqüência tende a normalidade, sendo mais evidente para $\mathrm{pH} \mathrm{em}$ água, principalmente do lado direito do histograma. $O$ ajuste dos pontos da reta de probabilidade normal foi perfeito para o conjunto de valores de $\mathrm{pH}$ em água. No caso do $\mathrm{pH} \mathrm{em} \mathrm{CaCl}_{2}$, o ajuste ficou comprometido nas extremidades da reta.

$\mathrm{O}$ índice de $\mathrm{pH}$ em água ideal para uma produção de grãos economicamente viável é de 5,5 a 6,3 , pois neste intervalo a planta tem boas condições de absorção dos nutrientes essenciais como: fósforo, potássio, enxofre e nitrogênio (Sousa \& Lobato, 2004). Em todas as amostras o $\mathrm{pH}$ em água esteve em torno de 5,4 . Apenas $25 \%$ dos resultados foram maiores do que 5,5. Porém, as deficiências de micronutrientes, especialmente de manganês e zinco, pode requerer que o $\mathrm{pH}$ não atinja um valor maior do que 6,0 (Goedert, 1983). 


\subsubsection{Acidez potencial}

O comportamento do solo como um ácido fraco, faz com que a maior parte do hidrogênio não esteja presente na forma dissociada. Em solos muito ácidos ocorre dissolução do alumínio, sendo um dos responsáveis pelos efeitos desfavoráveis da acidez do solo sobre os vegetais. A acidez potencial de um solo é constituída pelo hidrogênio não dissociável e o alumínio, mas somente este é um cátion trocável (Raij, 1991). A acidez potencial é determinado integralmente, incluindo hidrogênio e alumínio, utilizando as soluções de cloreto de bário tamponado com trietanolamina a pH 8,2, o acetato de cálcio $1 \mathrm{~N}$ a pH 7,0 e a solução tampão SMP.

A curva de distribuição para a acidez potencial do solo tende à normal, pois a média e mediana são praticamente iguais. O coeficiente de assimetria é próximo de zero, indicando uma distribuição simétrica. $O$ coeficiente de curtose negativo indica uma curva de distribuição do tipo mesocurtica, devido ao fato deste valor estar próximo de zero.

A variabilidade dos resultados de acidez potencial pode ser considerada média, pois o CV foi da ordem de $20,5 \%$. O elevado valor da variância e desvio padrão define que há uma grande dispersão dos resultados neste conjunto.

$\mathrm{Na}$ Figura 2 estão apresentados o histograma, a reta de probabilidade normal e o gráfico de "Box-plot", para as determinações da acidez potencial do solo. A demonstração visual por meio do histograma, para aquilo que foi presumido pelos parâmetros estatísticos de posição, mostra que a tendência a uma distribuição normal está mais evidente no lado esquerdo do histograma de freqüências. Na reta de probabilidade normal, pode-se observar um bom ajuste dos pontos. A flutuação dos pontos na parte inferior da reta é a que representa justamente o lado direito do histograma. Pelo gráfico de "Box-plot", observa-se razoável simetria na distribuição com tendência assimétrica negativa. 


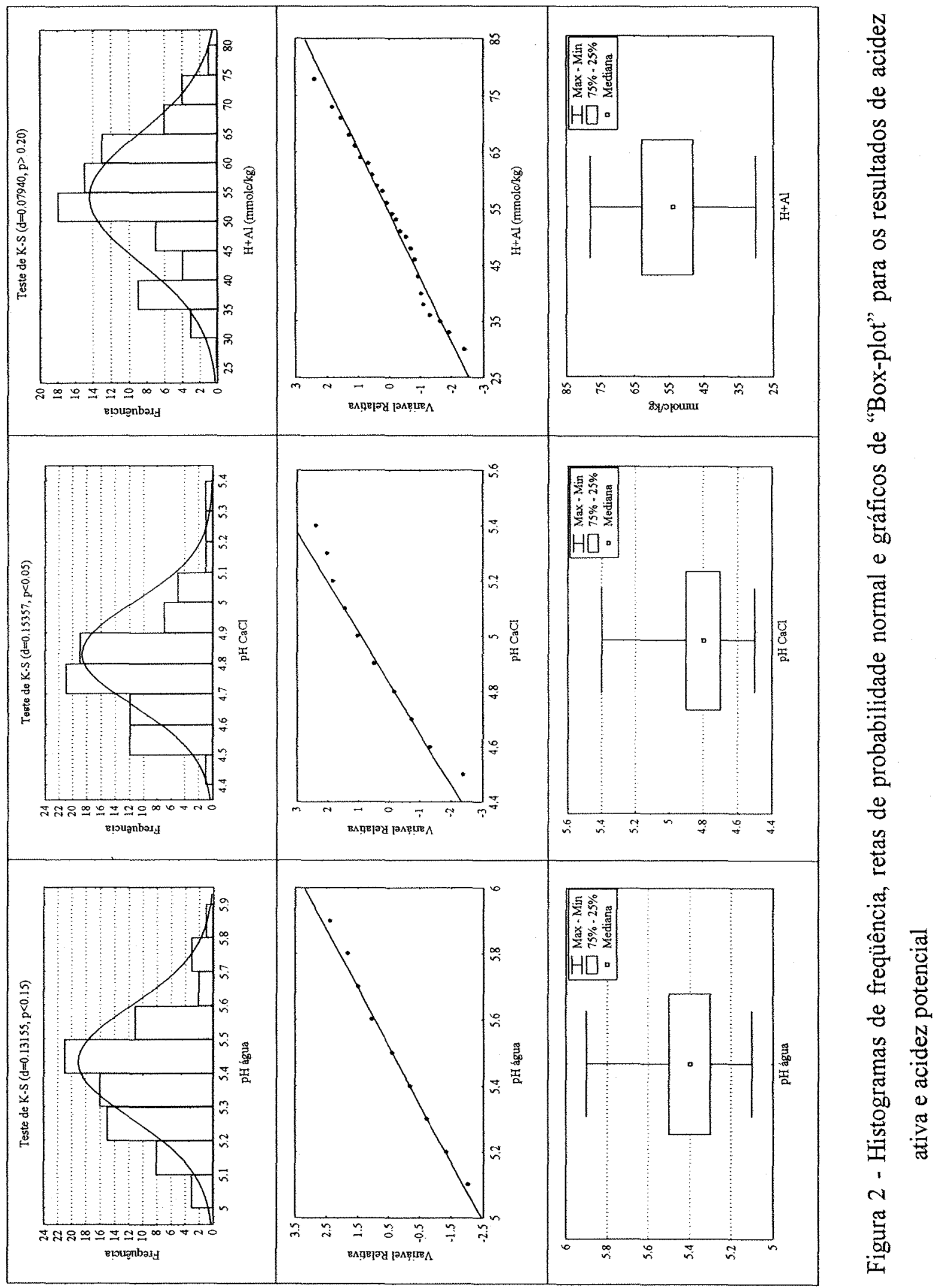




\subsubsection{Matéria orgânica e parâmetros de fertilidade}

Na tabela 3 estão apresentados os parâmetros estatísticos descritivos para o teor de matéria orgânica (MO), e os resultados calculados para soma de bases (SB), capacidade de troca de cátions a $\mathrm{pH} 7,0$ (T) e saturação por bases (V), que serão discutidos na seqüência.

Tabela 3. Parâmetros estatísticos descritivos para os teores de matéria orgânica (MO), soma de bases (SB), capacidade de troca de cátions a pH 7,0 (T) e saturação por bases (V), na camada de 0 a $20 \mathrm{~cm}$, em Latossolo sob rotação soja/milho

\begin{tabular}{|c|c|c|c|c|}
\hline Parâmetros Avaliados & MO & $\mathrm{SB}^{1}$ & $\mathrm{~T}^{2}$ & $\mathrm{~V}^{3}$ \\
\hline & $\mathrm{g} \mathrm{kg}^{-1}$ & \multicolumn{2}{|c|}{$\ldots \mathrm{mmol}_{\mathrm{c}} \mathrm{kg}^{-1} \ldots$} & $\%$ \\
\hline $\mathrm{N}^{\mathrm{Q}}$ de amostras & 80 & 80 & 80 & 80 \\
\hline Média & 46,79 & 37,66 & 91,72 & 41,31 \\
\hline Mediana & 48,50 & 37,25 & 94,78 & 41,04 \\
\hline Mínimo & 29,00 & 23,86 & 60,92 & 29,14 \\
\hline Máximo & 61,00 & 54,33 & 122,24 & 57,99 \\
\hline Quartil inferior & 43,50 & 32,79 & 84,15 & 36,76 \\
\hline Quartil superior & 52,00 & 41,67 & 99,42 & 45,79 \\
\hline Amplitude & 32,00 & 30,47 & 61,32 & 28,85 \\
\hline Variância & 60,47 & 40,76 & 180,79 & 36,61 \\
\hline Desvio Padrão & 7,78 & 6,38 & 13,45 & 6,05 \\
\hline $\mathrm{CV}(\%)$ & 16,62 & 16,94 & 14,66 & 14,64 \\
\hline Assimetria & $-0,89$ & 0,18 & $-0,25$ & 0,23 \\
\hline Curtose & 0,10 & $-0,17$ & 0,03 & $-0,34$ \\
\hline
\end{tabular}

\subsubsection{Matéria orgânica}

A média e a mediana, para os teores de MO, apresentaram uma diferença em relação aos seus valores, indicando a não tendência de distribuição normal dos resultados para está variável. A distribuição dos teores tende a uma assimetria, pois o 
valor do coeficiente de assimetria reforça esta afirmação. Ocorre aqui, também como no caso da acidez potencial do solo, mas que para os teores de MO ficou mais evidente, que $o$ valor do coeficiente de assimetria foi negativo. $O$ coeficiente de curtose revela que a curva de distribuição e do tipo mesocurtica. Para este conjunto não houve uma proximidade entre os resultados desses dois coeficientes.

Os teores de MO apresentaram um CV médio, segundo a classificação de Warrick \& Nielsen (1980), mostrando que esta variável apresenta uma média variabilidade dos resultados na área de estudo. Pode-se verificar também, que os valores de variância e o desvio padrão para os teores de MO foram bem menores, em comparação com os resultados para os componentes granulométricos do solo.

O histograma, a reta de probabilidade normal e o gráfico de "Box-plot", para os teores de MO do solo, estão apresentados na Figura 3. Fica claro agora que a curva de distribuição não tende a uma normal, pelo que pode ser verificado pelo teste de Kolmogorov-Smirnov, e também que a assimetria é negativa, como foi interpretado por meio do valor do coeficiente de assimetria. É interessante observar que existe uma flutuação dos pontos em relação à reta de probabilidade normal. Pelo gráfico de "Boxplot" podemos visualizar melhor o comportamento assimétrico dos teores de MO do solo, que segue o mesmo em relação ao conteúdo de argila.

Nota-se a similaridade que existe entre as distribuições de freqüência para o conteúdo de argila e o teor de MO no solo. O teor de MO é útil para dar idéia da textura

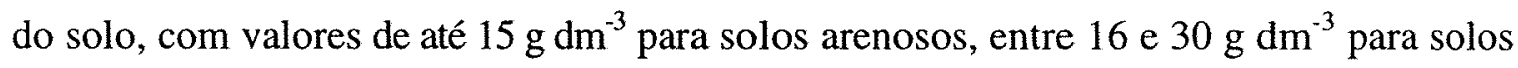
de textura média e de 31 a $60 \mathrm{~g} \mathrm{dm}^{-3}$ para solos argilosos. Valores muito acima de $60 \mathrm{~g}$ $\mathrm{dm}^{-3}$ indicam acúmulo de matéria orgânica por condições localizadas, em geral por má drenagem ou acidez elevada (Raij et al., 1997). As dimensões da área interferem na distribuição dos resultados desses atributos, não possuindo estes uma distribuição normal, como foi verificado para a MO (Cambardella, et al., 1994; Souza et al., 1998) e para argila (Salviano et al., 1998) 


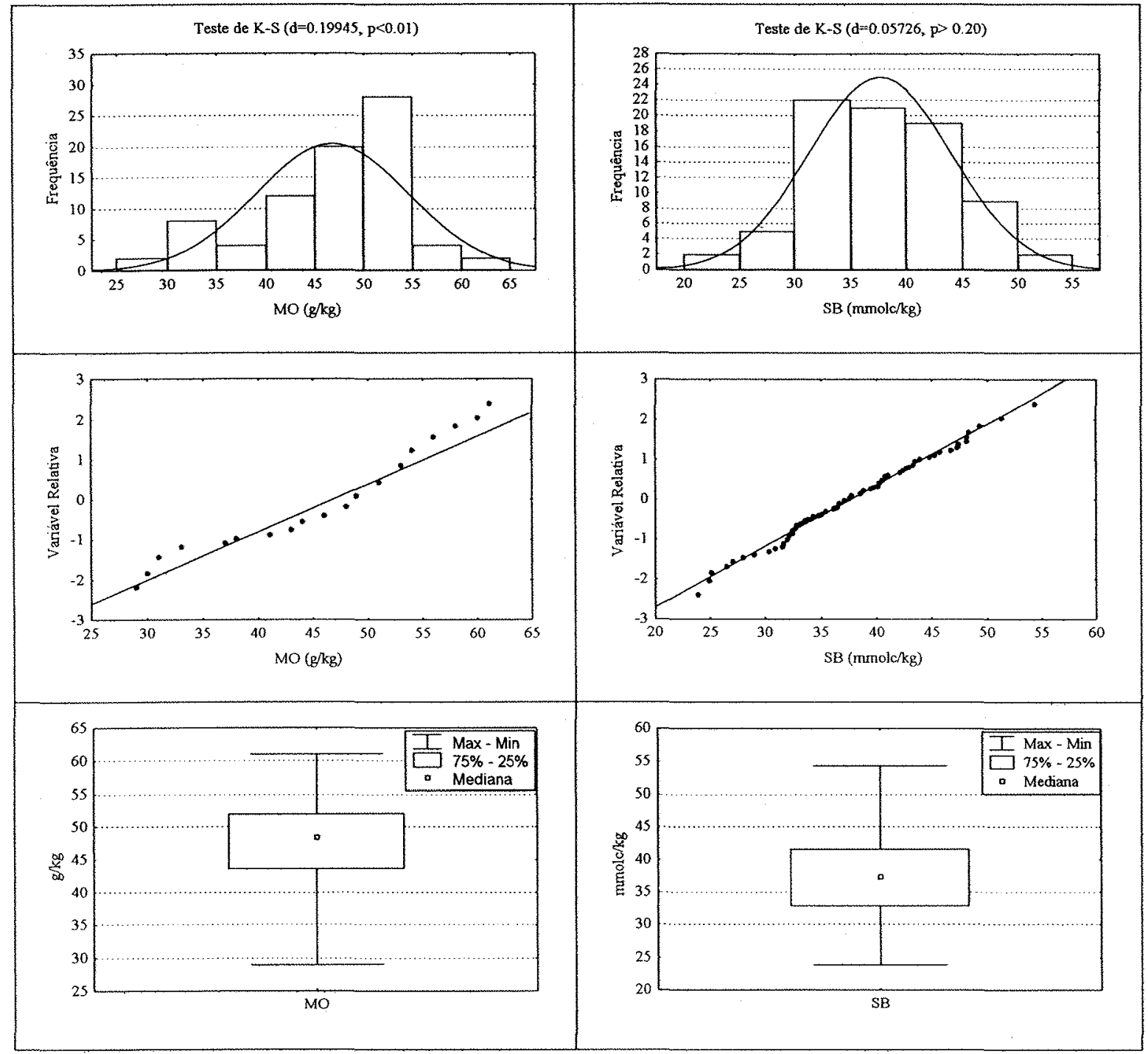

Figura 3 - Histogramas de freqüência, retas de probabilidade normal e gráficos de "Boxplot" para os resultados de matéria orgânica e soma de bases

\subsubsection{Soma de bases}

Observa-se na Tabela 3 , que valores da média e mediana, para os resultados de SB $\left(\mathrm{Ca}^{2+}+\mathrm{Mg}^{2+}+\mathrm{K}^{+}\right)$, podem ser considerados iguais. Assim, a distribuição dos valores de SB apresenta a tendência de seguir uma curva normal. $O$ coeficiente de assimetria condiz com essa afirmação, demonstra que os valores calculados de SB são simetricamente distribuídos. E o parâmetro estatístico referente ao coeficiente de curtose 
indica uma curva de distribuição do tipo mesocurtica, pois o seu valor se aproxima de zero.

A variabilidade dos valores de SB é considerada média, pelo CV que é da ordem de $16,94 \%$, segundo o critério proposto por Warrick \& Nielsen (1980). A dispersão dos resultados, em torno de média, é menor em comparação com o comportamento dos valores de $\mathrm{T}$, levando-se consideração as medidas de variabilidade.

A Figura 3 mostra o histograma, a reta de probabilidade normal e o gráfico de "Box-plot", construídos a partir dos valores calculados de SB. A curva de distribuição dos valores tende a uma distribuição normal. Na reta de probabilidade normal, pode-se observar o bom ajuste dos pontos. Sabendo-se que no cálculo da SB consideramos a soma dos valores de $\mathrm{Ca}, \mathrm{Mg}$ e $\mathrm{K}$, determinados no complexo de troca do solo, nota-se que a distribuição dos teores destes elementos está influenciando na distribuição dos resultados para o parâmetro de fertilidade considerado neste item. O gráfico de "Boxplot" indica melhor a simetria da curva de distribuição.

\subsubsection{Capacidade de troca de cátions}

A diferença entre os valores da média e da mediana, para a capacidade de troca de cátions a pH 7,0 (T), mostra que a curva de distribuição dos resultados não obedece a uma distribuição normal. O valor do coeficiente de assimetria indica, porém, uma simetria na distribuição dos resultados de T. O formato da curva pode ser interpretado por meio do coeficiente de curtose, neste caso o valor do coeficiente foi aproximadamente igual a zero, o qual prevê uma curva do tipo mesocurtica para a distribuição dos resultados.

O CV para os resultados de $T$ indica que os valores calculados para este parâmetro apresentam uma média variabilidade. Os resultados de variância e desvio padrão foram altos, mostrando que a dispersão dos valores desta variável em relação à média é bastante elevada. Pode-se verificar isto pelo valor da amplitude para dos resultados de $\mathrm{T}$, levando-se em consideração a correlação que existe entre esses parâmetros estatísticos. 
A análise estatística descritiva dos resultados de T está apresentada na forma de histograma de frequiência, reta de probabilidade normal e gráfico de "Box-plot", pela Figura 4. O teste não-paramétrico de Kolmogorov-Smirnov revela que a distribuição é simétrica. Ainda, por meio do histograma de freqüência, nota-se que o lado direito tende visualmente a uma distribuição mais próxima da normal. Observa-se que este lado corresponde ao lado esquerdo no histograma de frequiência, para os resultados de $\mathrm{H}+\mathrm{Al}$, por ser estas variáveis inversamente proporcionais. $\mathrm{Na}$ reta de probabilidade normal, pode-se visualizar uma certa flutuação dos pontos em relação à reta, como ocorreu com a MO. Pelo gráfico de "Box-plot", pode-se observar que o valor da mediana não coincide com o centro da caixa, que representa $50 \%$ dos valores da T do solo. Por esta informação, confïma-se a diferença que existe entre os valores da média e mediana.

Em trabalhos desenvolvidos com 29 das amostras de solos do Cerrado do médio Araguaia, utilizadas por Sousa (1988), com teor médio de 48\% (30 a 78\%) de argila; de $2,04 \%\left(0,55\right.$ a 3,59\%) de MO; e de 8,29 $\mathrm{cmol}_{\mathrm{c}} \mathrm{dm}^{-3}\left(4,88\right.$ a $\left.13,18 \mathrm{cmol}_{\mathrm{c}} \mathrm{dm}^{-3}\right)$ de T, utilizando-se o método gráfico de Bennema (Bennema, 1966), observou-se que 88\% (75 a 93\%) da capacidade de troca de cátions provinha da MO. Esses valores indicam a essencialidade da MO nesses solos para que os nutrientes catiônicos permaneçam na camada arável, região esta de grande importância para o desenvolvimento das plantas. Quando maior a CTC do solo menores serão as perdas dos nutrientes por lixiviação, aumentando o efeito residual dos corretivos de acidez do solo. 


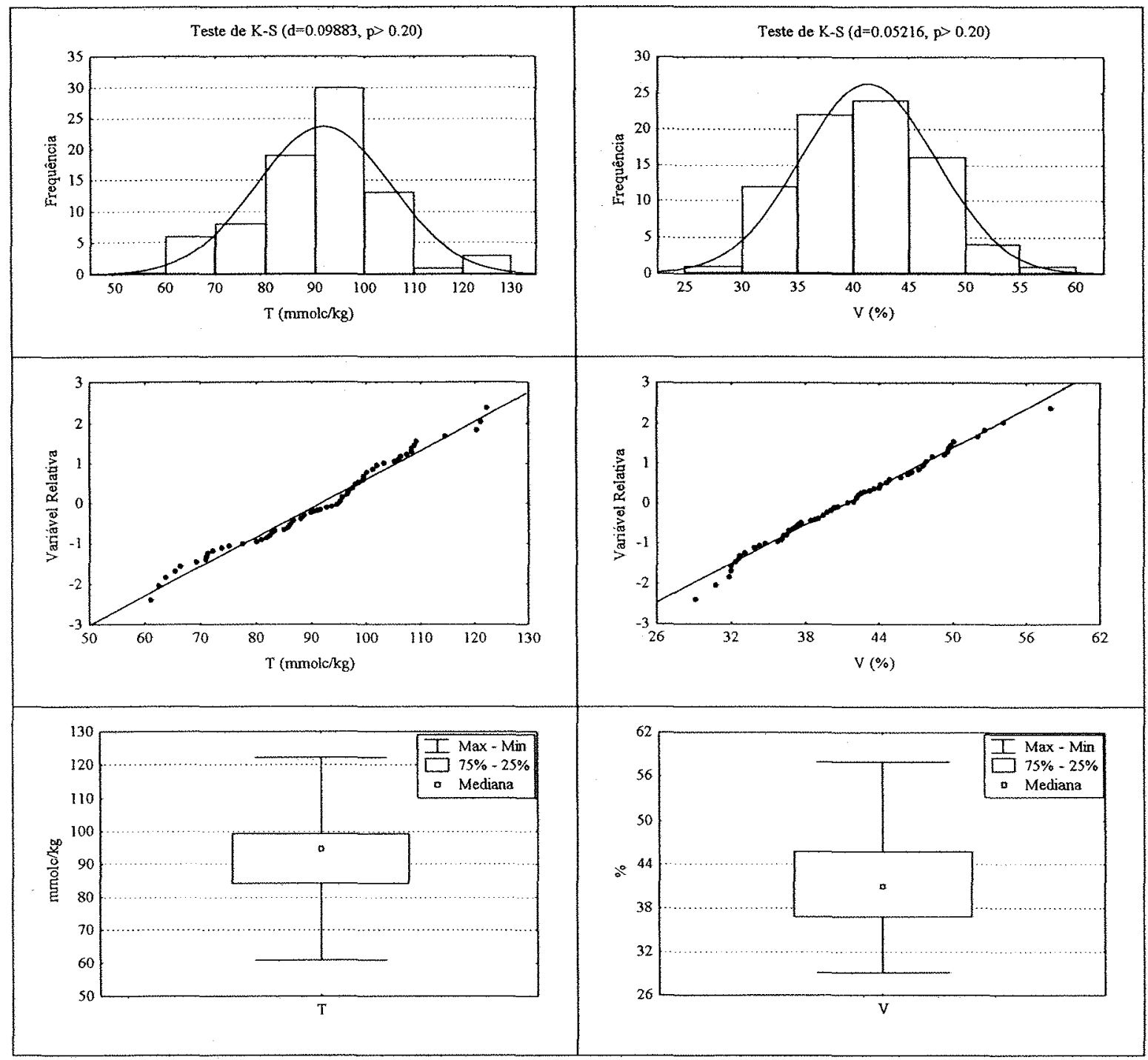

Figura 4 - Histogramas de freqüência, retas de probabilidade normal e gráficos de "Boxplot" para os resultados de capacidade de troca catiônica a pH 7,0 e saturação por bases

\subsubsection{Saturação por bases}

A saturação por bases (V) é um dos parâmetros utilizado para recomendação da correção da acidez do solo na região do Cerrado. Dados obtidos experimentalmente indicam que a produtividade de grãos aumenta com a saturação por bases até $40 \%$, estabiliza entre valores de 40 e $60 \%$ e diminui quando a saturação por bases é maior que 
$60 \%$. Para valores de saturação por bases maiores que $60 \%$, o pH em água do solo será maior que 6,3 e, nessa situação, poderá ser induzida à deficiência de zinco, cobre, ferro e manganês, essa última muito freqüente na região do Cerrado (Sousa \& Lobato, 2004).

Os valores da média e mediana, para os valores calculados de $\mathrm{V}$, estão próximos um do outro. Portanto, com relação ao critério que está sendo adotado, o qual considerou próximos os valores dessas medidas estatísticas de tendência central para os resultados de SB, também considera próximos os valores dessas medidas para o índice V. Assim, pode-se dizer que os valores calculados da variável em questão possuem tendência a uma distribuição normal. $O$ valor positivo do coeficiente de curtose indica que a curva de distribuição tende ao tipo mesocurtica.

A variabilidade do índice $\mathrm{V}$ pode ser considerada média, pois o valor encontrado para o CV foi da ordem de 14,64\%. Assim, considerando o critério disposto em Warrick \& Nielsen (1980), os conjuntos de resultados de MO, SB, T e V, apresentaram média variabilidade. Como tem ocorrido para os seguintes parâmetros de fertilidade do solo, $\mathrm{H}+\mathrm{Al}$, SB e $\mathrm{T}$, também no caso do índice $\mathrm{V}$, os valores da variância e desvio padrão foram elevados. Conforme discutido no item sobre a $T$, pode-se inferir que a dispersão dos valores de $\mathrm{H}+\mathrm{Al}$, em torno da média, estaria influenciando também a dispersão dos parâmetros de fertilidade calculados a partir dos resultados desta determinação.

$\mathrm{Na}$ Figura 4 está apresentado o histograma de freqüências, a reta de probabilidade normal e o gráfico de "Box-plot", para os valores calculados do índice de saturação por bases (V). A curva de distribuição mostra uma tendência a normal, como sugere o valor do coeficiente de assimetria. Houve um bom ajuste dos pontos à reta de probabilidade normal. Pode-se visualizar de maneira mais clara a distribuição dos resultados pelo gráfico de "Box-plot", mostrando que há uma certa simetria na distribuição dos resultados, com uma pequena dispersão dos valores acima do quartil superior. 


\subsubsection{Macronutrientes}

Na tabela 4 estão apresentados os parâmetros estatísticos descritivos para as concentrações dos macronutrientes (exceto o $\mathrm{N}$ ) no solo que serão discutidos na sequiência.

Tabela 4. Parâmetros estatísticos descritivos para os teores de macronutrientes (menos o N) na camada de 0 a $20 \mathrm{~cm}$, em Latossolo sob rotação soja/milho

\begin{tabular}{|c|c|c|c|c|c|}
\hline Parâmetros Avaliados & $\mathrm{P}$ & $\mathrm{S}$ & $\mathrm{K}$ & $\mathrm{Ca}$ & $\mathrm{Mg}$ \\
\hline & \multicolumn{2}{|c|}{ - $\mathrm{mg} \mathrm{kg}^{-1}$} & \multicolumn{3}{|c|}{$\ldots \operatorname{mmol}_{\mathrm{c}} \mathrm{kg}^{-\mathrm{I}}$} \\
\hline № de amostras & 80 & 80 & 80 & 80 & 80 \\
\hline Média & 22,24 & 8,21 & 2,84 & 26,08 & 8,74 \\
\hline Mediana & 19,45 & 7,30 & 2,83 & 26,12 & 8,46 \\
\hline Mínimo & 6,76 & 3,90 & 2,18 & 15,58 & 5,59 \\
\hline Máximo & 60,88 & 16,90 & 3,71 & 38,46 & 13,63 \\
\hline Quartil inferior & 14,20 & 6,00 & 2,62 & 22,78 & 7,29 \\
\hline Quartil superior & 25,53 & 10,35 & 3,02 & 29,46 & 9,83 \\
\hline Amplitude & 54,11 & 13,00 & 1,53 & 22,88 & 8,04 \\
\hline Variância & 133,82 & 9,04 & 0,10 & 24,35 & 3,77 \\
\hline Desvio Padrão & 11,57 & 3,01 & 0,32 & 4,93 & 1,94 \\
\hline $\mathrm{CV}(\%)$ & 52,02 & 36,63 & 11,25 & 18,92 & 22,20 \\
\hline Assimetria & 1,54 & 0,88 & 0,61 & 0,10 & 0,68 \\
\hline Curtose & 2,21 & 0,14 & 0,29 & $-0,26$ & 0,03 \\
\hline
\end{tabular}

\subsubsection{Fósforo}

Os resultados indicam que o teor de $\mathrm{P}$ disponível (extrator Resina) não possui distribuição próxima da normalidade. Primeiro, os valores da média e mediana são bem diferentes, indicando uma distribuição assimétrica do $\mathrm{P}$ no solo. Segundo, o coeficiente de assimetria não está próximo a zero, o que poderia indicar uma distribuição simétrica dos resultados de P. Pelo contrário, o resultados para o coeficiente indica forte assimetria 
positiva para o conjunto dos teores de $\mathrm{P}$. O valor positivo para o coeficiente de curtose mostra que a curva de distribuição é do tipo leptocurtica.

O CV da ordem de $52 \%$ indica uma grande variabilidade em torno da média. No trabalho de Salviano et al. (1998) o P, nas duas camadas de solo analisadas também apresentou alto $\mathrm{CV}$, o que foi atribuído à aplicação de fertilizantes em linha, ao efeito residual da adubação e à exposição de camadas mais pobres desse nutriente, decorrente do processo de erosão superficial. Os valores mínimo e máximo de $\mathrm{P}$ retratam bem o alto CV obtido em relação ao nutriente (Silveira et al., 2000). No entanto, a amplitude total deve ser vista com muita reserva, já que esta medida leva em consideração apenas os dois valores extremos de um conjunto, sendo, muitas vezes, afetada por um valor particularmente discrepante (Salviano et al., 1998).

A distribuição de frequiência na forma de histogramas, a reta de probabilidade normal e os quartis de $\mathrm{P}$ disponível no solo estão representados na Figura 5. O resultado referente ao teste de Kolmogorov-Smirnov indicou uma distribuição assimétrica corroborando com o que foi concluído por meio da análise estatística de posição e pelo formato da curva de distribuição de frequêencia. Pela reta de probabilidade visualiza-se um imperfeito ajuste entre os pontos e a reta.

$\mathrm{O}$ teor de $\mathrm{P}$ em solos sob vegetação nativa de Cerrado é bem menor do que 8 a 10 $\mathrm{mg} \mathrm{kg}{ }^{-1}$, que é o intervalo requerido para a maioria dos cereais cultivados (Goedert, 1983). Para esses solos a adubação fosfatada corretiva é necessária para obter boas produtividades da cultura logo no primeiro ano. Estando o solo corrigido, recomenda-se a adubação de manutenção baseada na exportação do nutriente. $\mathrm{Na}$ área em estudo, 96,25\% das amostras apresentaram teores acima do nível crítico necessitando apenas de adubação de manutenção para a cultura (Sousa et al., 2004). Observando o histograma na Figura 5, nota-se que a maior frequiência de valores para P está contida entre 10 a 20 $\mathrm{mg} \mathrm{kg}^{-1}$. Para fins de recomendação de adubação, o produtor teria a opção de não realizar ou aplicar apenas a quantidade prevista na exportação pela cultura, dependendo de sua estratégia de manejo. Portanto, na visão de manejo homogêneo da área, a tomada de decisão seria no intuito de considerar este resultado. Para a recomendação de $\mathrm{P}$ à taxas variáveis, seriam definidos limites intermediários do nível adequado e alto. Por 
exemplo, nos talhões onde os teores de $\mathrm{P}$ foram classificados como altos poderia ser dispensada a adubação. Enquanto, nos talhões com teores adequados realizaria a adubação baseada na quantidade potencial do elemento exportado pela cultura.

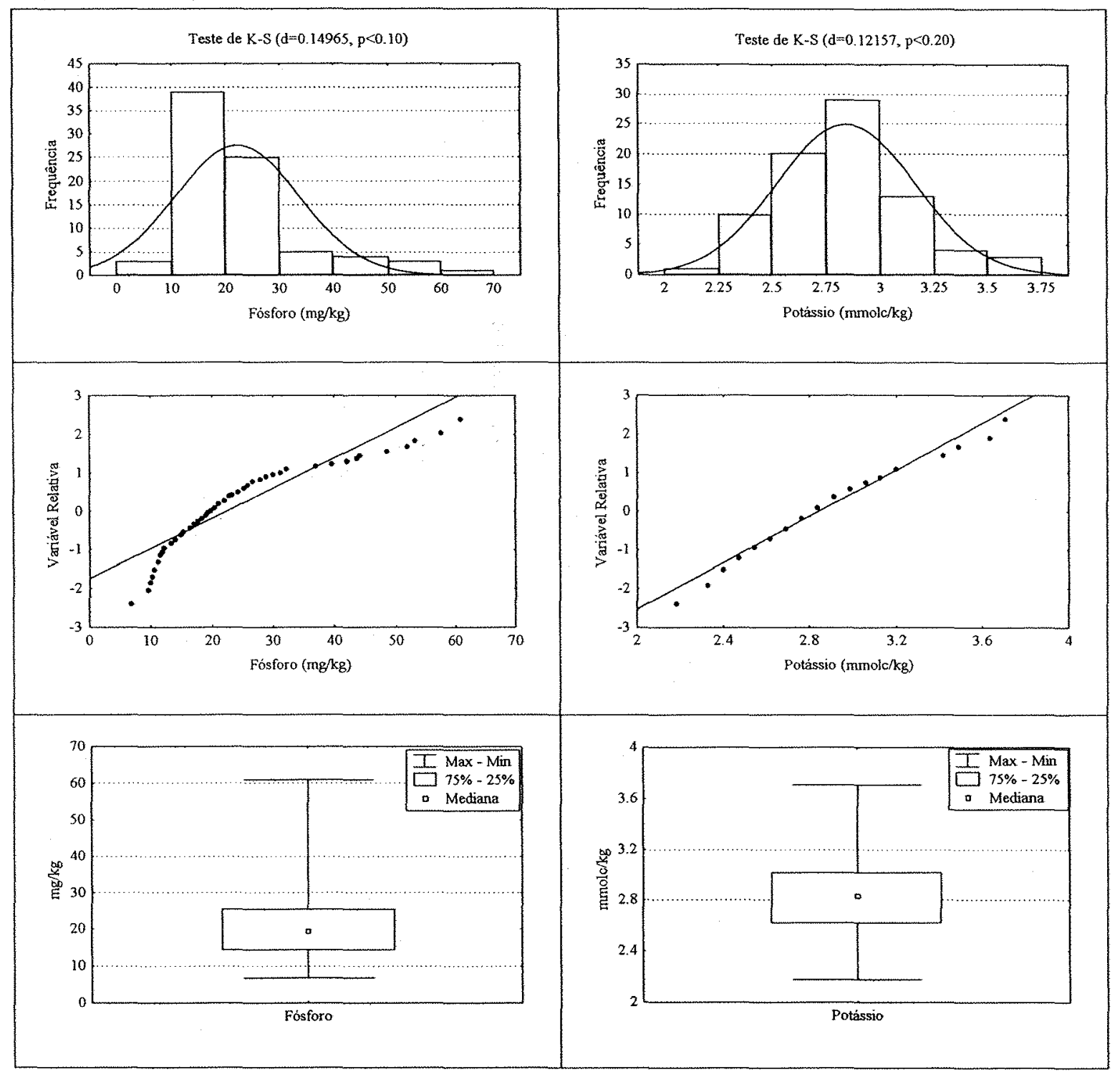

Figura 5 - Histogramas de freqüência, retas de probabilidade normal e gráficos de "Boxplot" para os teores de fósforo e potássio 


\subsubsection{Potássio}

Nota-se que os valores de média e mediana dos teores de $\mathrm{K}$ são praticamente iguais, indicando uma distribuição normal dos resultados. O coeficiente de assimetria possui um valor relativamente próximo a zero, assim pode ser sugerida uma tendência à distribuição simétrica para esses resultados. O coeficiente de curtose próximo a zero confirma a tendência de uma distribuição normal para as concentrações de $\mathrm{K}$ no solo.

$\mathrm{O} \mathrm{CV} \mathrm{e} \mathrm{o} \mathrm{desvio} \mathrm{padrão} \mathrm{da} \mathrm{ordem} \mathrm{de} 11,3 \% \mathrm{e} 0,32 \mathrm{mmol}_{\mathrm{c}} \mathrm{kg}^{-1}$, respectivamente, demonstraram uma baixa variabilidade e variação dos teores em torno do valor médio. A amplitude dos resultados para o $\mathrm{K}$ no solo pode ser considerada pequena quando em comparação com a amplitude calculada para os valores de Ca e $\mathrm{Mg}$.

O formato da curva de distribuição e o histograma de freqüência demonstraram uma tendência à normal para os teores de potássio no solo (Figura 5). Observa-se pela reta da probabilidade normal que os pontos se ajustaram melhor a reta, ao contrário do que ocorreu com o fósforo. Há, porém, um pequeno afastamento dos pontos nas extremidades da reta. No gráfico de "Box-plot" observa-se uma certa simetria para o conjunto dos teores de $\mathrm{K}$ no solo.

A interpretação dos teores de $\mathrm{K}$ trocável mostrou não haver limitação para este elemento. Os resultados de exatamente 60 amostras estão contidos na classe de teor médio no solo. A maioria dos solos, sob vegetação de Cerrado, possui menos que 0,15 $\mathrm{cmol}_{\mathrm{c}} \mathrm{K} / 100 \mathrm{~g}$ de solo, considerado como nível critico para as culturas anuais (Goedert, 1983). Lopes (1975), a partir dos resultados de 518 amostras do Brasil Central, verificou que $85 \%$ continham teores inferiores ao nível crítico. Pode-se inferir que no início da ocupação agrícola do Cerrado, as respostas à adubação potássica foram freqüentes. Atualmente, o efeito residual das sucessivas adubações tem contribuído para uma menor resposta à aplicação deste elemento.

\subsubsection{Cálcio}

Assim como ocorreu para o $\mathrm{K}$, podemos inferir também para o Ca que a distribuição dos resultados tende a uma normal, pois como para o primeiro, neste os valores da média e mediana foram próximos (Tabela 4). Pode-se reforçar esta afirmação, 
pelo baixo coeficiente de assimetria, muito próximo a zero. Também próximo a zero é o resultado para o coeficiente de curtose indicando uma distribuição do tipo mesocúrtica.

Com relação à variabilidade dos resultados de Ca no solo, pode-se considerá-la como média, devido o fato do CV ter sido da ordem de $18,9 \%$, segundo classificação proposta por Warrick \& Nielsen (1980). O desvio padrão em relação ao teor médio de $\mathrm{Ca}$ foi de aproximadamente cinco unidades, ou seja, dentre os cátions básicos determinados no solo e representados pela mesma unidade, o conjunto dos teores de $\mathrm{Ca}$ foi o que apresentou a maior dispersão dos valores em torno da média. Portanto, o valor da amplitude para o elemento no solo foi alto, como pode ser observado pela Tabela 4.

$\mathrm{O}$ histograma de frequiências, a reta de probabilidade normal e o gráfico de "Boxplot", para os teores de Ca no solo estão apresentados na Figura 6. O resultado do teste não-paramétrico de Kolmogorov-Smirnov indicou distribuição normal para os teores de Ca. O que já se presumia pela observação dos parâmetros estatísticos de posição, apresentados na Tabela 4. Vale ressaltar que o teste confirmou a normalidade da distribuição, em todos os níveis de significância $(p>0,20)$. Um perfeito ajuste dos pontos a reta de probabilidade normal, pode ser visualizado na Figura 2. No gráfico de "Boxplot", percebe-se uma perfeita simetria da distribuição dos resultados de Ca obtidos pelo extrator Resina.

Os resultados da analise química para os teores de Ca no solo, foram maiores do que $15 \mathrm{mmol}_{\mathrm{c}} \mathrm{kg}^{-1}$ e menores que $40 \mathrm{mmol}_{\mathrm{c}} \mathrm{kg}^{-1}$. Este intervalo é considerado como pertencente à classe de teor baixo no solo, segundo Raij et al. (1997). A calagem nesta área foi realizada no ano agrícola de $2000 / 2001 \mathrm{com} 800 \mathrm{~kg} \mathrm{ha}^{-1}$, considerando o efeito residual dessa aplicação nos anos agrícolas de 2001/2002, 2002/2003 e 2003/2004. Isto explica os baixos teores de Ca determinados. A prática da calagem, dentre outras intervenções recomendadas, possibilitou o sucesso agrícola do Cerrado, por melhorar as condições químicas do solo. Porém, no Brasil Central as recomendações de calcário devem evitar o uso de doses elevadas por diminuir a possibilidade de deficiência de micronutrientes para as plantas. 


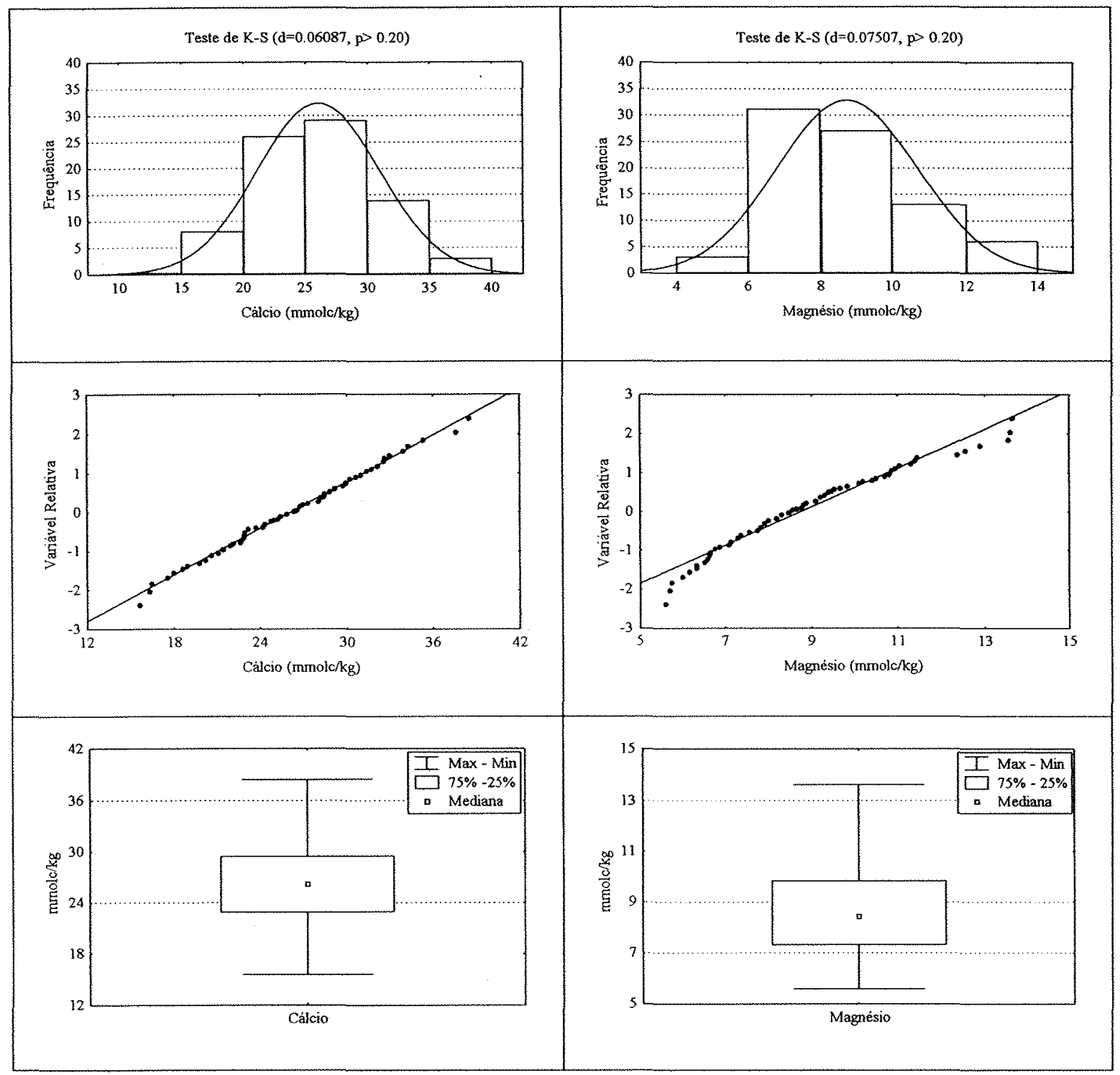

Figura 6 - Histogramas de freqüência, retas de probabilidade normal e gráficos de "Boxplot" para os teores de cálcio e magnésio

\subsubsection{Magnésio}

Pela Tabela 4, pode-se visualizar o resultado para cada um dos parâmetros estatísticos descritivos do teor de $\mathrm{Mg}$ trocável, determinado pelo extrator Resina. Para este caso, a média e mediana possuem valores relativamente próximos. O resultado do coeficiente de assimetria para este conjunto foi parecido com o resultado calculado para 
- K. Significa, portanto, que ocorre uma distribuição próxima da normal para os resultados de $\mathrm{Mg}$. O valor do coeficiente de curtose indica que a distribuição dos teores deste elemento é representada por uma curva do tipo mesocurtica.

O CV foi da ordem de $22,2 \%$ sendo pertencente à classe que define os atributos com média variabilidade, segundo Warrick \& Nielsen (1980). Existe uma diferença considerável entre o valor mínimo e máximo, não sendo tão expressiva como ocorreu no caso do $\mathrm{Ca}$.

$\mathrm{Na}$ figura 6, o comportamento dos teores determinados de $\mathrm{Mg}$ são apresentados na forma de histograma, reta de probabilidade normal e gráfico de box-plot. Porém se visualiza uma certa flutuação dos pontos em relação à reta de probabilidade normal, principalmente nas extremidades do gráfico. $\mathrm{O}$ formato do gráfico de box-plot reforça $\mathrm{o}$ resultado calculado para o coeficiente de assimetria, o qual mostra que este conjunto de valores tende a uma assimetria positiva. Pode-se visualizar a maior dispersão acima do quartil superior.

As relações de Ca: $\mathrm{Mg}$ devem estar contidas no intervalo de 1:1 a um máximo de 10:1, respeitando-se sempre o teor mínimo de $0,5 \mathrm{cmol}_{\mathrm{c}} \cdot \mathrm{dm}^{-3}$ de $\mathrm{Mg}$ no solo (Sousa \& Lobato, 2004). Não se observa pela análise do solo uma condição crítica com relação ao teor de $\mathrm{Mg}$. Pelo contrário, mais da metade das amostras apresentaram teores de $\mathrm{Mg}$ considerado alto, segundo os critérios de interpretação estabelecidos por Raij et al., (1997). Para as relações de Ca:Mg os valores calculados se situaram entre 1:2 e 1:4, ou seja, consideradas relações estreitas. Quaggio et al. (1985) observaram que o milho respondeu igualmente à aplicação de calcários com diferentes teores de magnésio, mostrando que a cultura, aparentemente, é pouco sensível a variações na relação Ca:Mg do solo e essas devem afetar a produção apenas se atingirem valores extremos ou se um dos elementos estiver presente em concentrações muito baixas no solo.

\subsubsection{Enxofre}

A partir desta Tabela 4, podemos verificar que há uma diferença de aproximadamente uma unidade entre os valores calculados da média e mediana, para os teores de $S$ no solo. O coeficiente de assimetria não esta próximo a zero, porém, ao 
mesmo tempo pode causar dúvidas quanto ao tipo de distribuição. Existem tabelas com os limites de aceitabilidade para os valores de assimetria como a tabela de Jones (1969). Porém, alguns pesquisadores preferem fixar um valor de aceitabilidade para assimetria, como Paz et al. (1996), que aceitaram a hipótese de normalidade quando os valores de assimetria distanciaram-se de zero até no máximo 1. A construção do histograma de freqüência junto com a reta de probabilidade normal para estes resultados, ajuda a visualizar e definir se esses possuem uma distribuição que tende a normal. O coeficiente de curtose para este elemento foi o que mais se aproximou de zero, indicando uma curva do tipo mesocurtica.

O CV foi da ordem de $36,7 \%$ considerado pertencente à classe de atributos de média variabilidade. Porém este valor foi maior do que os CVs calculados para $\mathrm{K}$, Ca e $\mathrm{Mg}$. Os teores de $\mathrm{S}$ e $\mathrm{P}$ apresentaram as maiores variabilidades no solo, comparativamente.

A curva de distribuição de frequiência no histograma apresentou um comportamento que não se aproxima o de uma distribuição assimétrica positiva (Figura 7). $\mathrm{O}$ ajuste dos pontos a reta de probabilidade normal confirma a discussão acima, pois os pontos tenderam ao afastamento em relação à reta, principalmente nas extremidades. Pelo gráfico de "Box-plot", conclui-se melhor sobre assimetria da distribuição, mostrando que analisar apenas o valor do coeficiente de assimetria, utilizando-se do limite de aceitabilidade para distribuições normais proposta por Paz et al. (1996) pode levar a uma conclusão equivocada. Percebe-se também que a mediana não coincide com a média ou não esta bem próxima do centro da caixa.

Segundo Rein \& Sousa (2004), na classe de média disponibilidade a resposta das culturas a adubação com $\mathrm{S}$ é incerta, mas recomenda-se aplicá-lo, principalmente, em áreas bem adubadas com os demais nutrientes para os quais há expectativas de bons rendimentos. Elevado teor de S na camada arável, é devido à classe textural do solo, sendo que solos mais arenosos possuem baixa capacidade de adsorção de sulfatos. Porém, este não é o caso nesta área de estudo, pois os conteúdos de argila ficaram entre 380 e $790 \mathrm{~g} \mathrm{~kg}^{-1}$ (Tabela 1). A acumulação de S, na camada superficial, pode ser explicada pela época do ano que antecede o período de amostragem, a qual se 
caracteriza por baixa precipitação pluviométrica, $20 \%$ dela concentrada nos meses de maio a outubro. Tanto o nitrato quanto o sulfato são produtos da mineralização da matéria orgânica que é contínua durante o ciclo da cultura e variável com as condições ambientais (Rein \& Sousa, 2004).

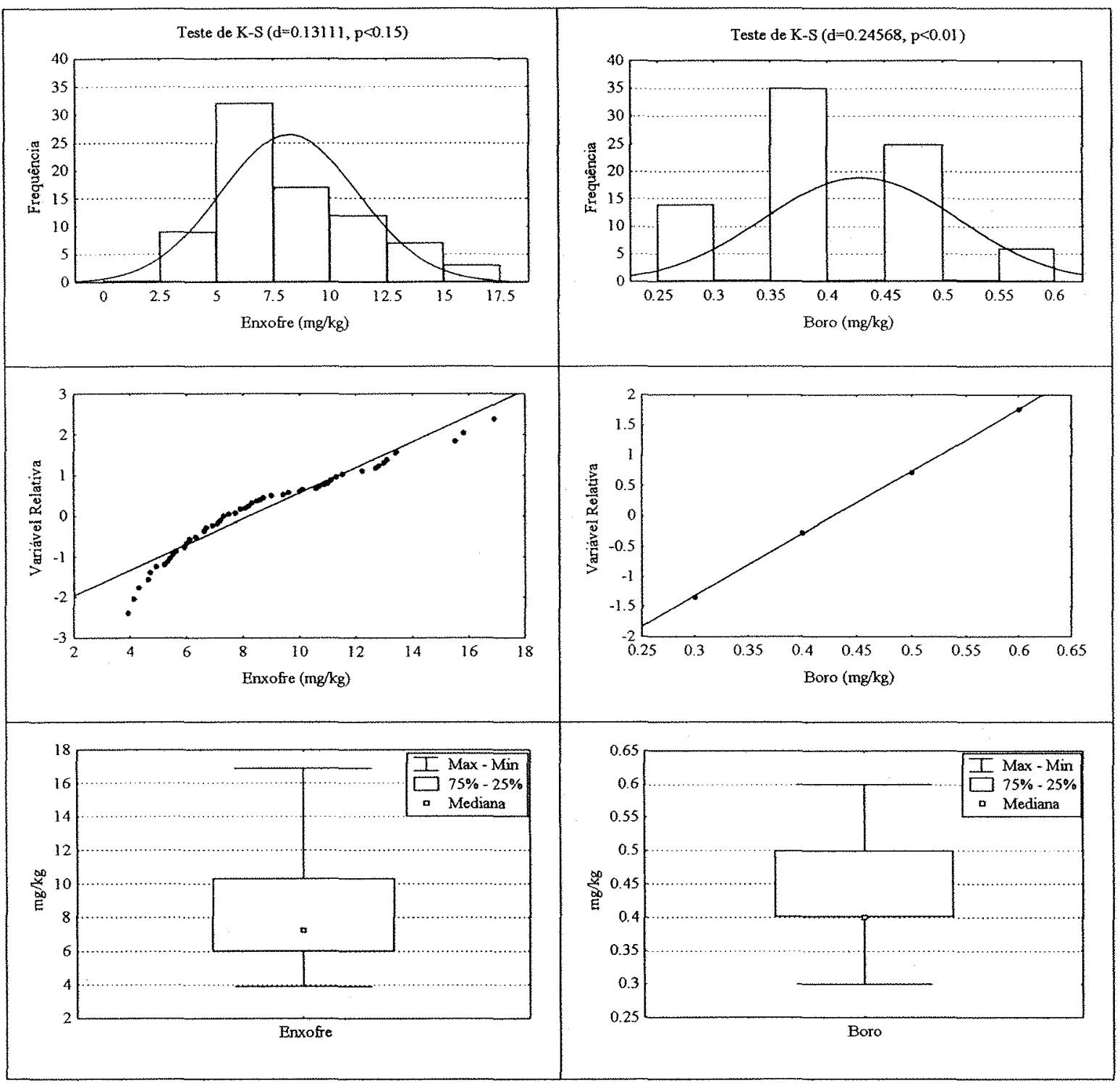

Figura 7 - Histogramas de freqüência, retas de probabilidade normal e gráficos de "Boxplot" para os teores de enxofre e boro 


\subsubsection{Micronutrientes}

A disponibilidade dos micronutrientes, $\mathrm{B}, \mathrm{Cu}, \mathrm{Fe}, \mathrm{Mn}$ e $\mathrm{Zn}$, é afetada por produtividades crescentes que aceleram a remoção pelas culturas, reduzindo o teor de micronutrientes no solo. Outro fator que interfere na disponibilidade é a aplicação de quantidades muito elevadas de calcário (Raij, 1991). Acrescenta-se a isso o fato de que na região do Cerrado, alguns dos micronutrientes são originalmente pouco disponíveis no solo, notadamente $\mathrm{B}$ e $\mathrm{Zn}$.

$\mathrm{Na}$ tabela 5 estão apresentados os parâmetros estatísticos descritivos para teores dos micronutrientes, $\mathrm{B}, \mathrm{Cu}, \mathrm{Fe}, \mathrm{Mn}$ e $\mathrm{Zn}$ no solo, que serão discutidos na seqüência.

Tabela 5. Parâmetros estatísticos descritivos para os teores de $\mathrm{B}, \mathrm{Cu}, \mathrm{Fe}, \mathrm{Mn}$ e $\mathrm{Zn}$ na camada de 0 a $20 \mathrm{~cm}$, em Latossolo sob rotação soja/milho

\begin{tabular}{|c|c|c|c|c|c|}
\hline Parâmetros Avaliados & $\mathrm{B}$ & $\mathrm{Cu}$ & $\mathrm{Fe}$ & $\mathrm{Mn}$ & $\mathrm{Zn}$ \\
\hline & \multicolumn{5}{|c|}{$\mathrm{mg} \mathrm{kg}^{-1}$} \\
\hline $\mathrm{N}^{\mathrm{o}}$ de amostras & 80 & 80 & 80 & 80 & 80 \\
\hline Média & 0,43 & 0,44 & 18,42 & 1,73 & 2,16 \\
\hline Mediana & 0,40 & 0,34 & 17,61 & 1,41 & 1,63 \\
\hline Mínimo & 0,30 & 0,17 & 12,44 & 0,85 & 0,69 \\
\hline Máximo & 0,60 & 1,33 & 30,94 & 4,41 & 6,90 \\
\hline Quartil inferior & 0,40 & 0,27 & 15,90 & 1,23 & 1,05 \\
\hline Quartil superior & 0,50 & 0,50 & 20,65 & 1,81 & 2,93 \\
\hline Amplitude & 0,30 & 1,16 & 18,50 & 3,56 & 6,21 \\
\hline Variância & 0,01 & 0,07 & 12,39 & 0,70 & 1,91 \\
\hline Desvio Padrão & 0,08 & 0,27 & 3,52 & 0,84 & 1,38 \\
\hline $\mathrm{CV}(\%)$ & 19,70 & 60,53 & 19,11 & 48,58 & 63,86 \\
\hline Assimetria & 0,18 & 1,53 & 0,94 & 1,92 & 1,25 \\
\hline Curtose & $-0,52$ & 1,65 & 1,22 & 2,92 & 1,43 \\
\hline
\end{tabular}




\subsubsection{Boro}

Pelas medidas de tendência central, dos teores de $\mathrm{B}$, pode-se inferir que a distribuição tende a uma normal, visto serem próximos os valores da média e da mediana. Aliado a isto, o coeficiente de assimetria foi semelhante a zero. O coeficiente de curtose para as concentrações de $B$, com um valor negativo indica que a curva de distribuição possui uma tendência ao tipo platicurtica.

O desvio padrão para os teores de B no solo apresentou um baixo valor, mostrando que há pouca dispersão dos resultados em torno de um valor médio. $\mathrm{O} C V$ é considerado como médio, portanto, os teores de B no solo, neste estudo de caso, possuem uma variabilidade média, segundo classificação proposta por Warrick \& Nielsen (1980).

$\mathrm{Na}$ figura 7 são apresentados o histograma, a reta de probabilidade normal e o gráfico de "Box-plot". Verifica-se pela reta de probabilidade normal que há um ajuste perfeito dos pontos a reta, nota-se também a pequena densidade de valores neste gráfico. Pelo gráfico de "Box-plot" verifica-se também a perfeita simetria dos teores de boro, mas também a não coincidência dos valores de média e mediana, sendo esta posicionada exatamente sobre o valor referente ao quartil inferior.

A cultura do milho tem baixa sensibilidade à deficiência de $\mathrm{B}$ e Mo, média sensibilidade à de $\mathrm{Cu}, \mathrm{Fe}$ e Mn e alta para Zn (Martens \& Wertermann, 1991). O efeito da adição de boro foi estudado em vários tipos de solo, mas sem qualquer resposta (Cantarella, 1993). Galrão (1984), através da técnica de diagnose por subtração, em um ensaio de campo com um Latossolo Vermelho-Escuro, não encontrou repostas do milho a B. O elemento é muito afetado pelo $\mathrm{pH}$, pela textura do solo e pelo teor de $\mathrm{Ca}$, sendo que, para valores elevados de $\mathrm{pH}$ o elemento se torna menos disponível. Solos mais argilosos adsorvem mais o B e podem, assim, dificultar a absorção pelas plantas. Um fator muito importante para a disponibilidade do B é o teor de água no solo. Em condições secas as deficiências se acentuam, possivelmente pela menor liberação do elemento da MO (Raij, 1991). Resposta à aplicação de B pode ser observada em ano de baixa umidade relativa do ar e altas temperaturas no estágio de espigamento (Galrão \& Sousa, 1988). 


\subsubsection{Cobre}

A assimetria na distribuição dos teores de Cu pode ser verificada pela análise dos resultados na Tabela 5. Primeiramente a média e a mediana são bem diferentes em seus valores. O coeficiente de assimetria não está próximo a zero como ocorreria no caso de uma distribuição simétrica. O coeficiente de curtose indica uma curva de distribuição do tipo leptocurtica.

$\mathrm{O}$ valor do $\mathrm{CV}$ demonstra que os teores de $\mathrm{Cu}$ no solo apresentam uma alta variabilidade. Fato reforçado pela pronunciada diferença entre os valores máximo e mínimo, monstrando que há uma correlação entre o CV e a amplitude dos resultados. Além disso, devemos considerar a baixa dispersão dos resultados em torno da média, demonstrado pelo desvio padrão na Tabela 5, não se correlaciona com o resultado do $\mathrm{CV}$. Alta variabilidade para os teores de $\mathrm{Cu}$ foi encontrada também por Silveira \& Cunha (2002).

Na Figura 8 pode-se visualizar o histograma, a reta de probabilidade normal e o gráfico de "Box-plot" gerados a partir dos resultados do teor de $\mathrm{Cu}$ no solo. Pela curva de distribuição nota-se forte assimetria positiva para esta variável do solo. Esta assimetria é, melhor observada no gráfico de "Box-plot", onde $50 \%$ dos teores deste micronutriente estão concentrados em uma estreita faixa, o que pode ser também percebido pela baixa amplitude interquartílica. $\mathrm{Na}$ reta de probabilidade normal, percebe-se a grande flutuação dos pontos em relação à reta.

Altas produções em solos de Cerrado tem sido obtidas sem a adição desse micronutriente, embora sejam originalmente pobres (Lopes, 1975). O menor teor médio de $\mathrm{Cu}$ determinado por Galrão (1984), nas parcelas com omissão deste nutriente, foi de $0,4 \mathrm{mg} \mathrm{kg}^{-1}$. Porém não houve resposta à aplicação de $\mathrm{Cu}$, sugerindo que o nível crítico para um Latossolo Vermelho-Escuro distrófico, de textura argilosa, utilizado neste experimento, seja inferior aquele valor. Por outro lado, Verdésio (1986), citado em Galrão (2004), informa que no município de Barreiras, BA onde predominam o Latossolo Vermelho-Amarelo, de textura média (15\% a 35\% de argila) e Areias Quartzosas ( $<15 \%$ de argila), o uso de Cu é indispensável para o cultivo. 


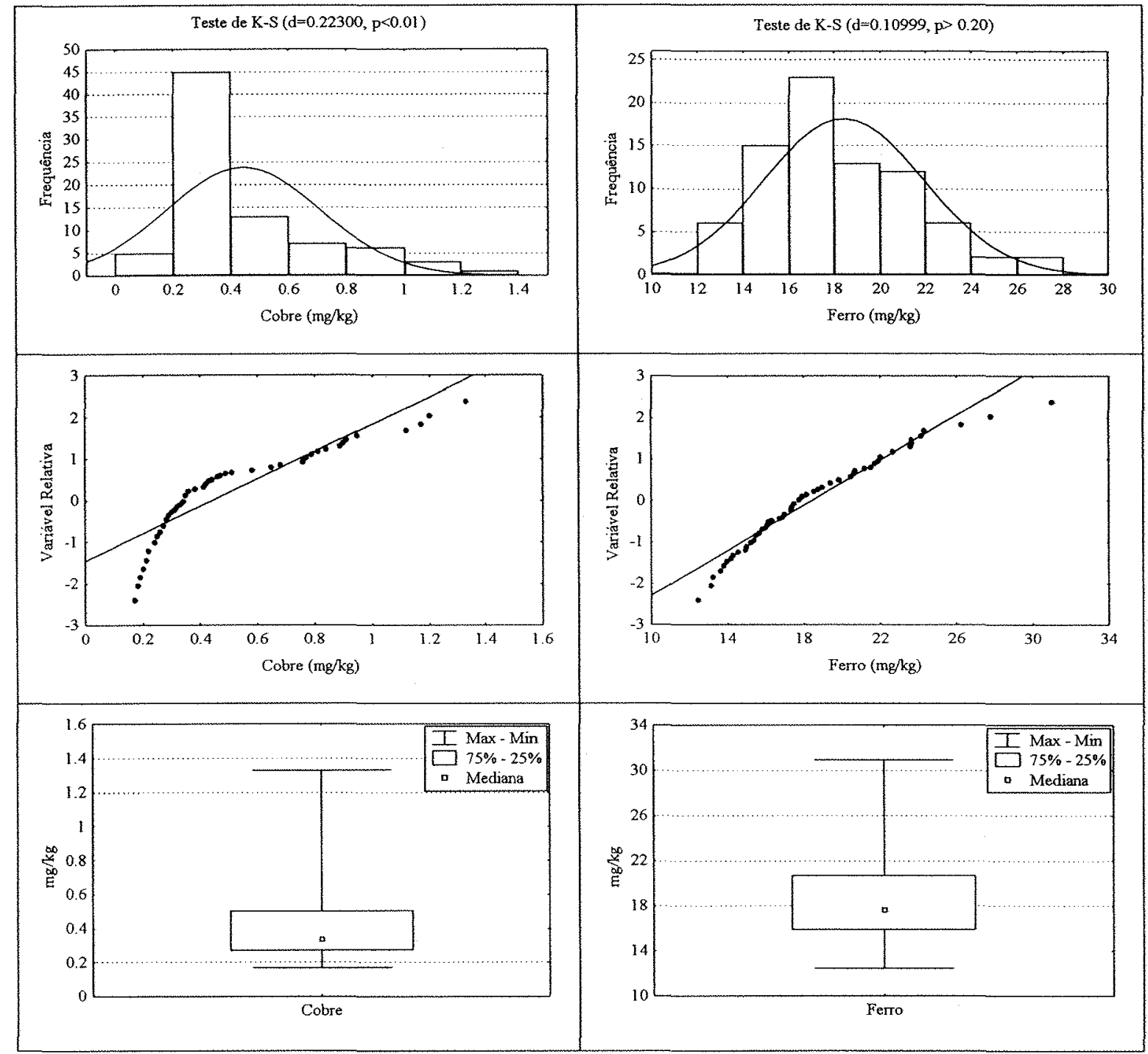

Figura 8 - Histogramas de freqüência, retas de probabilidade normal e gráficos de "Boxplot" para os teores de cobre e ferro

\subsubsection{Ferro}

A média e mediana, para os teores de Fe no solo, não apresentam valores próximos, e o resultado do coeficiente de assimetria para este nutriente indica que o conjunto dos teores de $\mathrm{Fe}$ possui uma tendência à distribuição assimétrica. $\mathrm{O}$ elevado valor do coeficiente de curtose reforça esta afirmação, indicando uma curva de distribuição do tipo leptocurtica. 
O CV da ordem de $19,1 \%$ mostra que elemento no solo tem uma variabilidade média, considerando o critério de Warrick e Nielsen (1980). Em termos comparativos é o menor $\mathrm{CV}$ dentre os micronutrientes determinados neste estudo. Silveira \& Cunha (2002) também concluiu que, de modo geral, o valor do CV apresentado pelo Fe foi menor em comparação com o $\mathrm{Zn}$. Embora tenha sido médio o valor do CV para os teores de $\mathrm{Fe}$, segundo o critério de Warrick \& Nielsen (1980), o valor da amplitude total foi maior do que o calculado para os demais micronutrientes, não seguindo o padrão de correlação com o CV. Como comentado anteriormente, a amplitude total deve ser vista com muita reserva, já que esta medida pode ser afetada por um valor particularmente discrepante (Salviano, et al., 1998).

O histograma de freqüências, a reta de probabilidade normal e o gráfico de "Boxplot", construídos a partir dos resultados de ferro no solo, são apresentados na Figura 8. No histograma de freqüência a curva de distribuição tende à normal, porém com certa assimetria à direita para os teores da variável em questão. Pela reta de probabilidade normal, observa-se um razoável ajuste dos pontos em relação à reta, a exceção dos pontos situados nas extremidades da reta. No gráfico de "Box-plot", pode-se visualizar melhor o comportamento assimétrico deste conjunto de resultados.

Em solos brasileiros os teores de Fe podem ser elevados, ultrapassando $10 \% \mathrm{em}$ alguns casos (Raij, 1991). Os resultados da análise química de 518 amostras de solos de Cerrado $(0$ a $15 \mathrm{~cm}$ ), indicaram que a mediana dos teores de $\mathrm{Fe}$, determinados pelo extrator Mehlich-1, foi de $32,5 \mathrm{mg} \mathrm{dm}^{-3}$ e a amplitude de variação calculada a partir dos valores mínimo e máximo de 3,7 a $74,0 \mathrm{mg} \mathrm{dm}^{-3}$, respectivamente. A maioria delas $(58 \%)$ possuía teores entre 25 e $40 \mathrm{mg} \mathrm{dm}^{-3}$. Não há qualquer sugestão de nível crítico de ferro solúvel para esses solos (Lopes, 1975).

\subsubsection{Manganês}

A média e mediana, para os teores de $\mathrm{Mn}$, não apresentam valores próximos o que significa que os resultados de Mn não seguem uma distribuição normal. O elevado coeficiente de assimetria para está variável, revela se tratar de uma distribuição assimétrica positiva, representada por uma curva do tipo leptocúrtica, devido ao valor 
calculado para o coeficiente de curtose. Pela análise dos resultados para cada um dos parâmetros estatísticos considerados neste estudo, pode-se inferir sobre o modelo probabilístico que segue cada conjunto.

O Mn possui uma média variabilidade na área com um CV da ordem de $48,6 \%$, estando próximo do limite superior para esta classificação proposta por Warrick e Nielsen (1980). O desvio padrão foi menor em comparação com os valores desse parâmetro calculados para os resultados de Fe e $\mathrm{Zn}$. Esta comparação só é possível, pois a unidade de medida é a mesma para todos os micronutrientes determinados neste estudo. Silveira \& Cunha (2002) relatou que a amplitude encontrada para o $\mathrm{Mn}$, foi relativamente baixa, se comparada com os valores encontrados para $\mathrm{Cu}, \mathrm{Fe}$ e $\mathrm{Zn}$. A exceção do $\mathrm{Cu}$, a comparação do $\mathrm{Mn}$, em termos de amplitude dos resultados, para com os outros dois micronutrientes é a mesma encontrada neste estudo.

$\mathrm{Na}$ Figura 9 estão apresentados o histograma, a reta de probabilidade normal e o gráfico de "Box-plot" para os teores de Mn no solo. A partir do histograma, podem ser visualizados os teores de $\mathrm{Mn}$ que aparecem com uma certa freqüência, mas estão isolados do restante do conjunto. Nota-se também que o resultado do teste nãoparamétrico de Kolmogorov-Smirnov para a variável em questão, foi muito parecido os resultados do teste para as variáveis, $\mathrm{Cu}$ e $\mathrm{B}$, inclusive com o mesmo grau de significância $(p<0,01)$, mostrando que as concentrações de $\mathrm{Mn}$ não apresentam distribuição normal.

O Mn tem sua disponibilidade reduzida pela elevação do $\mathrm{pH}$. Em geral, os solos de Cerrado são bem supridos de Mn (Lopes \& Cox, 1977). Doses elevadas de calcário podem induzir a deficiência de manganês, assim como a sua incorporação rasa ( 0 a 10 cm). Segundo Sousa et al. (1990), índices de saturação por bases, próximos a 70\%, são muito elevados para os solos da região do Cerrado que necessitam, para o desenvolvimento adequado da maioria das culturas, de um valor de saturação por bases em torno de $50 \%$. 


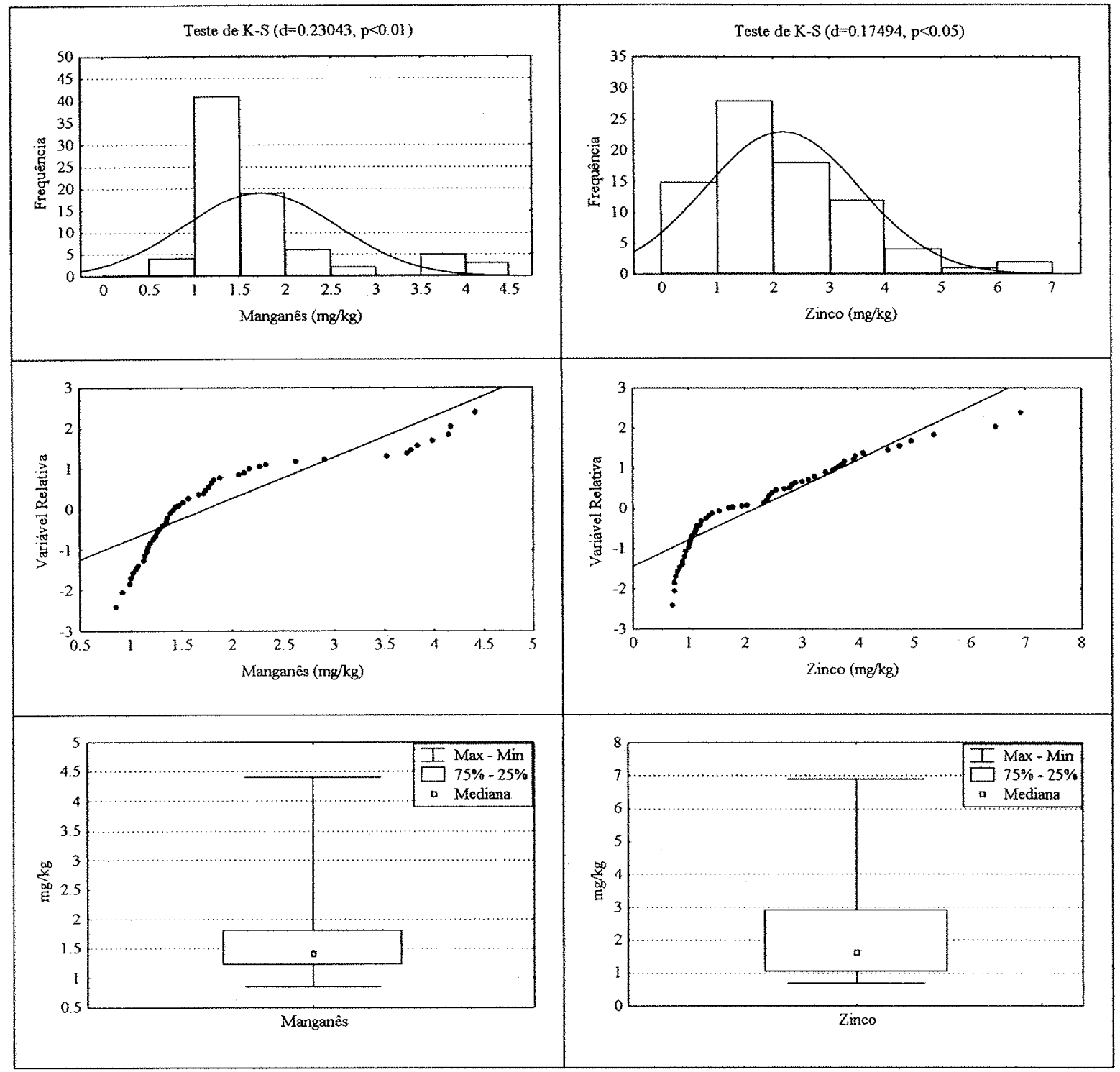

Figura 9 - Histogramas de freqüência, retas de probabilidade normal e gráficos de "Boxplot" para os teores de manganês e zinco

\subsubsection{Zinco}

Analisando os parâmetros estatísticos de tendência central, para os teores de $\mathrm{Zn}$ no solo, observa-se uma diferença entre os valores da média e mediana. Portanto, inferese que o comportamento dos teores de zinco no solo, determinados neste estudo, não segue uma distribuição normal. O coeficiente de assimetria indica que a distribuição é 
assimétrica. $O$ coeficiente de curtose mostra que a curva de distribuição apresenta o formato do tipo leptocúrtica. Todas essas característica não são típicas de uma distribuição normal para um conjunto de valores.

$\mathrm{O}$ teor de $\mathrm{Zn}$ no solo possui uma alta variabilidade com $\mathrm{CV}$ da ordem de $63,9 \%$, sendo este o mais elevado em comparação com os outros micronutrientes no solo. Esta variabilidade pode ser verificada também pelo alto valor da amplitude dos teores de $\mathrm{Zn}$, mostrando neste caso uma correlação entre estes parâmetros. Silveira \& Cunha (2002), encontrou tanto para o $\mathrm{CV}$, quanto para a amplitude total, valores maiores para o $\mathrm{Zn}$ em relação ao $\mathrm{Cu}$, mostrando que o primeiro elemento possui uma alta variabilidade no solo.

A Figura 9 mostra o histograma de freqüência, a reta de probabilidade normal e o gráfico de "Box-plot" para os teores de Zn no solo. No histograma, podemos verificar visualmente que o conjunto dos valores de $\mathrm{Zn}$ possui uma distribuição fortemente assimétrica. Os elementos que apresentaram distribuição fortemente assimétrica foram: $\mathrm{Cu}, \mathrm{Mn}$ e $\mathrm{Zn}$. Essa ordem foi estabelecida por meio do teste não paramétrico de Kolmogorov-Smirnov, apresentado no histograma. A faixa de teores entre quartil inferior e quartil superior, que representa $50 \%$ dos resultados de $\mathrm{Zn}$ no gráfico de boxplot, é mais larga do que ocorreu para o $\mathrm{Cu}$ e $\mathrm{Mn}$. Outra observação é o ajuste dos pontos na extremidade inferior da reta são semelhantes, se diferenciando o $\mathrm{Zn}$ das outros dois nutrientes no ajuste dos pontos ao longo da reta de probabilidade normal.

$\mathrm{O}$ micronutriente mais limitante a produção de milho no Brasil é o $\mathrm{Zn}$. A maior parte dos relatos sobre a deficiência desse elemento para o milho provém de solos Podzólicos ou de Latossolos altamente intemperizados e ácidos, da região dos Cerrados (Cantarella, 1993). O Zn tem sua solubilidade afetada pelo $\mathrm{pH}$, e calagens a valores de $\mathrm{pH}$ acima de 6,0 podem induzir deficiência. Além disso, o elemento é fortemente retido em solos àrgilosos, o que pode agravar a sua deficiência. Os fosfatos tendem a reduzir a solubilidade de Zn, e são conhecidas às deficiências induzidas por adubações fosfatadas elevadas (Raij, 1991). Ritchey et al (1986), utilizando um Latossolo do Cerrado, testaram três extratores e determinaram os seguintes níveis críticos para o milho: $1,4 \mathrm{mg}$ $\mathrm{kg}^{-1}$ (extração com $\mathrm{HCl} 0,1 \mathrm{~N}$ ), 1,0 mg kg-1 (extração com extrator de Mehlich-1) e 0,7 $\mathrm{mg} \mathrm{kg}^{-1}$ (extração com DTPA-TEA). 
Galrão (1984) mostrou o efeito do Zn no rendimento de grãos de arroz, milho e soja. Houve resposta porque a disponibilidade inicial deste elemento era muito baixa, de $0,4 \mathrm{mg} \mathrm{dm}^{-3}$, e estava abaixo do nível crítico de $1,0 \mathrm{mg} \mathrm{dm}^{-3}$, determinado pelo extrator Mehlich-1. Além disso, deve ser considerada a adubação fosfatada corretiva, a qual foi realizada com $800 \mathrm{~kg} \mathrm{ha}^{-1}$, divididos antes do primeiro e do terceiro cultivos. Não houve diferença significativa entre o tratamento completo e o com omissão de $\mathrm{Zn}$ a partir do quinto cultivo.

A recomendação de micronutrientes para solos de Cerrado, com base na análise química é bastante limitada (Galrão, 2004). A única exceção é o Zn cujo nível crítico, para uma planta exigente como o milho, é de $1,0 \mathrm{mg} \mathrm{dm}^{-3}$ para $\mathrm{pH}$ em água ao redor de 6,0. Esse valor para o nível crítico é menor em $\mathrm{pH}$ mais ácido, devido ao efeito deletério do $\mathrm{pH}$ sobre a disponibilidade dos micronutrientes catiônicos.

\subsubsection{Correlação com a produtividade}

O parâmetro estatístico que mede o grau de relação entre variáveis, e que procura determinar quão bem uma equação linear, ou de outra espécie, descreve ou explica a relação entre as variáveis, é conhecido como correlação (Spiegel, 1985). Se todos os valores das variáveis satisfazem exatamente uma equação, diz-se que elas estão perfeitamente correlacionadas ou há correlação perfeita entre elas.

A análise de correlação revelou que os maiores coeficientes encontrados foram aqueles que explicam a relação linear entre as medidas de acidez do solo ( $\mathrm{pH}$ e $\mathrm{H}+\mathrm{Al})$ e o teor de MO com os atributos de fertilidade dos solo (Tabela 6).

Destaque também para as correlações entre os micronutrientes e os atributos de fertilidade do solo, incluindo as medidas de acidez e os teores de MO. Dentre os nutrientes foram esses os, que em sua maioria, apresentaram coeficientes significativos com tais atributos (Tabela 7). Dentre os micronutrientes, particular atenção é dada para o $\mathrm{Cu}$ e o $\mathrm{Mn}$, os quais apresentaram correlações negativas com os parâmetros acidez potencial, capacidade de troca de cátions e MO. E correlações positivas com os resultados de saturação por bases do solo. 
Pode-se inferir pelos resultados que a menor disponibilidade de $\mathrm{Cu}$ e $\mathrm{Mn}$ no Cerrado está mais fortemente ligada as causas do sistema de plantio direto, o qual proporciona um aumento do teor de MO.

Os coeficientes de correlação entre os atributos do solo e os dados de altitude da área foram maiores em comparação aos coeficientes calculados para esses atributos e os dados de produtividade. (Tabela 6 e 7).

Em estudos de escala de campo normalmente não é possível isolar ou medir todos os fatores bióticos e abióticos que influenciam na produção da cultura. Neste estudo, os coeficientes de correlação linear de Pearson para a maioria dos atributos de fertilidade do solo versus produtividade do milho não foram significativos ao nível de $5 \%$ de probabilidade, com exceção da $\mathrm{MO}$ e os micronutrientes B, Cu, Mn e Zn (Tabela 6 e 7).

A análise de correlação entre os atributos de fertilidade do solo e os dados de produtividade de grãos, na cultura de milho implantada na área de coleta das amostras, revelou que os coeficientes significativos de correlação foram baixos, ou seja, menores que 0,50 . Destaque para as correlações negativas entre os teores de $\mathrm{Cu}, \mathrm{Mn}$ e $\mathrm{Zn}$ com os dados de produtividade. Para os coeficientes positivos de correlação entre os atributos de fertilidade e os dados de produtividade, destaque para aquele que relaciona a MO com a produtividade. $\mathrm{O}$ coeficiente significativo entre a $\mathrm{MO}$ e a produtividade demonstra a influência na disponibilidade de nutrientes às plantas e a importância desta como condicionadora da qualidade física de solos cultivados sob sistema de plantio direto.

Os coeficientes de correlação negativos para os micronutrientes $\mathrm{Cu}, \mathrm{Mn}$ e $\mathrm{Zn}$ versus produtividade estão diretamente ligados ao fornecimento anual desses nutrientes juntamente com as adubações e, pelo solo apresentar uma acidez elevada caracterizada pela média do $\mathrm{pH}$ em $\mathrm{CaCl}_{2}$ de 4,8; demonstrando assim um possível efeito negativo na produtividade pelos teores médios e altos de $\mathrm{Cu}, \mathrm{Mn}$ e $\mathrm{Zn}$ no solo.

Pode-se notar um comportamento semelhante dos dados de produtividade e altitude com relação aos atributos de fertilidade. A altitude como medida indireta do relevo da área, por inferência, é a que mais influencia os resultados desses atributos, comparativamente aos dados de produtividade. 


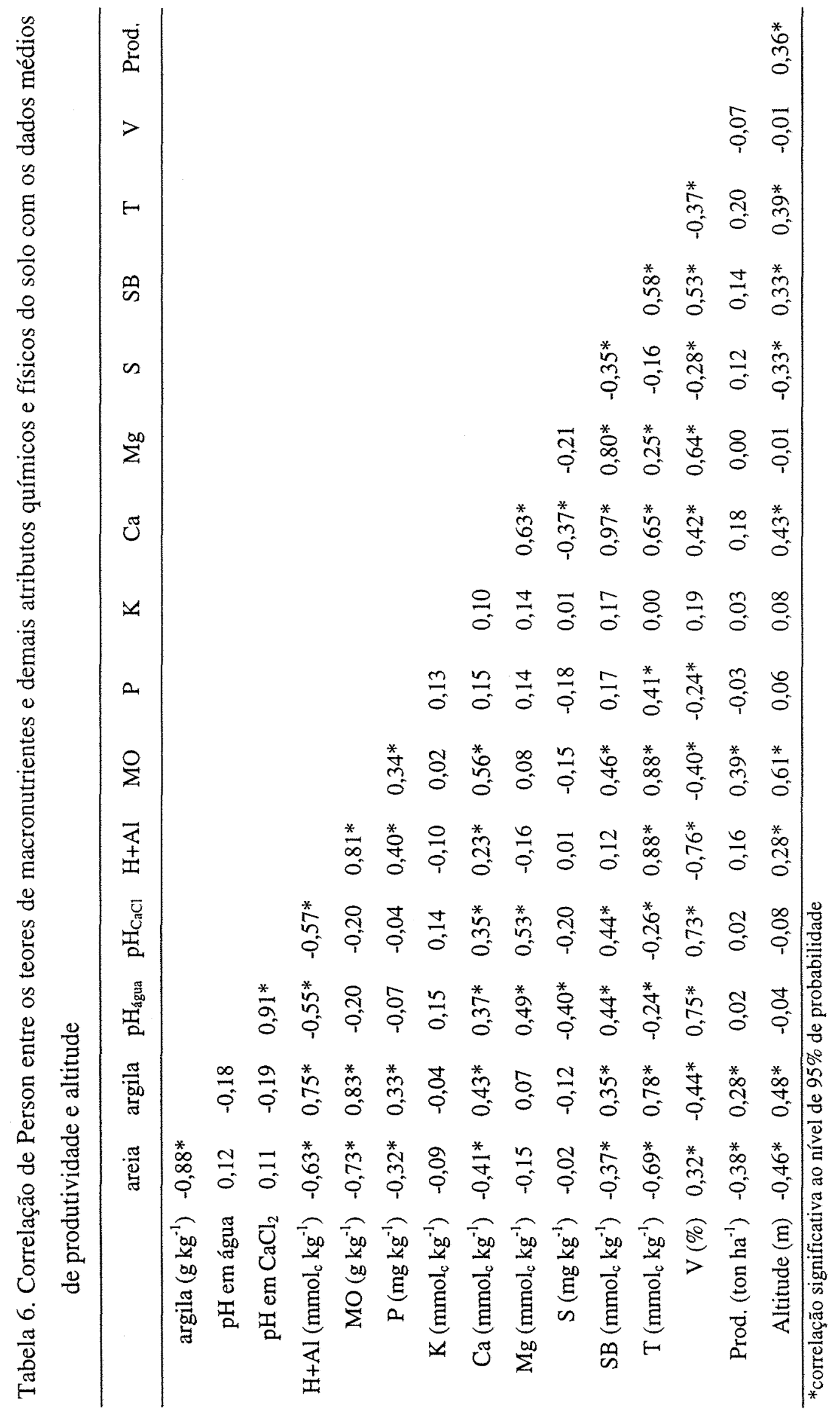




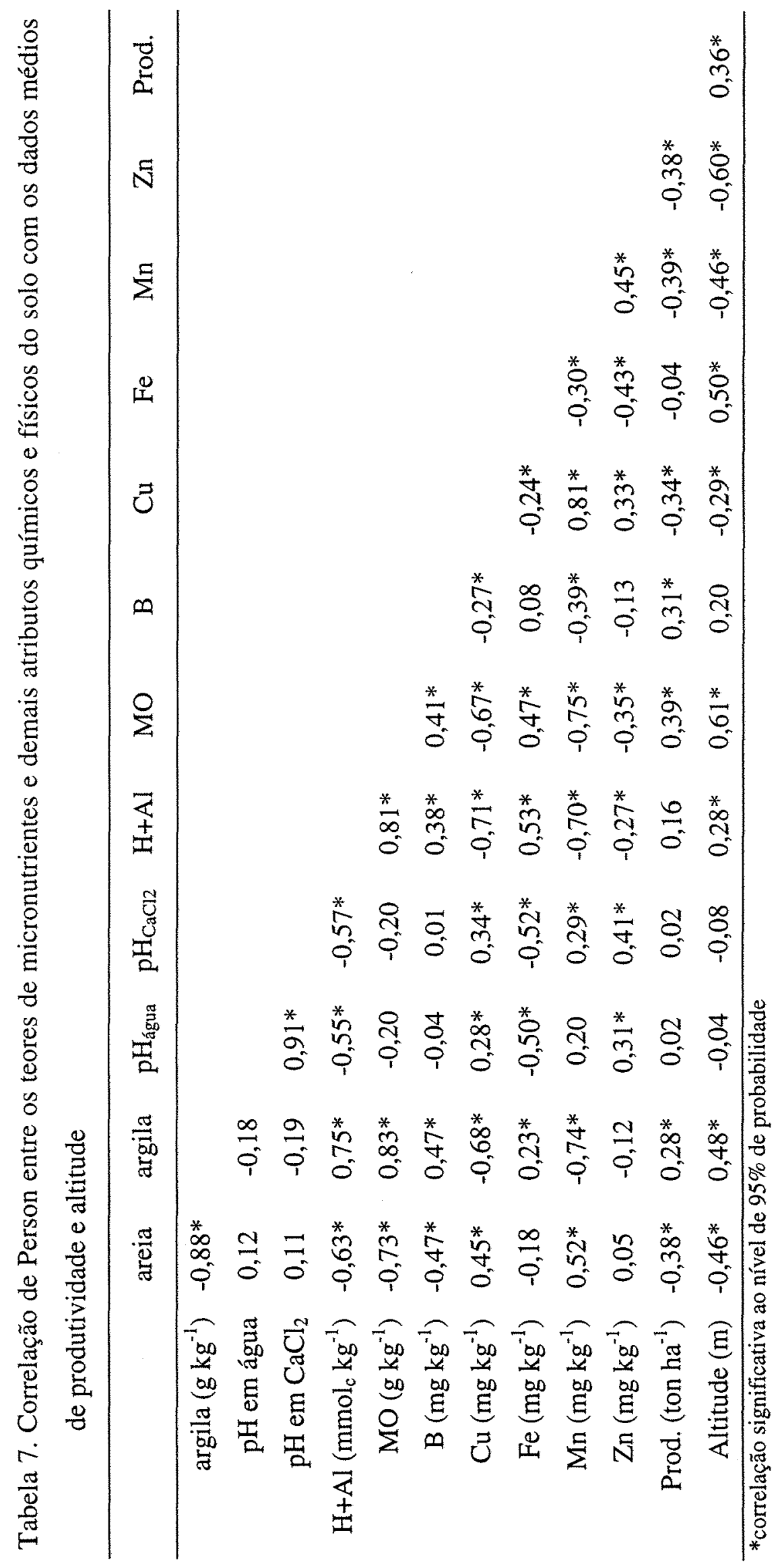




\subsection{Conclusões}

Os atributos de fertilidade do solo apresentaram baixa, média e alta variabilidade para a área de estudo.

A prática da correção da acidez do solo e adubações a serem realizadas na área do estudo devem considerar a variabilidade da fertilidade do solo.

O manejo da matéria orgânica do solo é fundamental para melhorar a produtividade dos cultivos.

Neste estudo as correlações lineares das variáveis com a produtividade da cultura são normalmente baixas pois não é possível isolar todos os fatores envolvidos. 


\section{VARIABILIDADE DA NUTRIÇÃO MINERAL DE PLANTAS DE MLLHO EM UM TALHÃO MANEJADO HOMOGENEAMENTE}

\section{Resumo}

O conhecimento da variabilidade da nutrição de plantas em áreas cultivadas pode trazer importantes subsídios para auxiliar no manejo da fertilidade do solo. O objetivo deste estudo de caso foi avaliar a variabilidade da nutrição mineral de plantas de milho por meio da análise foliar num talhão manejado homogeneamente e verificar possíveis relações com a produtividade da cultura. $O$ estudo de caso foi conduzido na Fazenda Alto Alegre em Planaltina - GO, numa área de 373 hectares de um Latossolo cultivada com milho na safra 2003/04. Traçado um polígono da área procedeu-se divisão em 80 células de manejo de quatro hectares cada. A amostragem da folha indicadora da célula seguiu uma diagonal com doze pontos e coletaram-se três folhas por ponto de plantas diferentes para compor a amostra composta. As coordenadas desses pontos foram obtidas e arquivadas. Realizou-se a análise dos macros e micronutrientes das folhas do milho. A produtividade para cada célula foi obtida por meio da colhedora equipada com Sistema de Posicionamento Geográfico (GPS) e monitor de rendimento de grãos. $\mathrm{Na}$ análise da variabilidade dos dados foram considerados parâmetros estatísticos descritivos. A análise de regressão linear simples dos dados da fertilidade com a

produtividade do milho foi realizada. A variabilidade da concentração dos nutrientes na folha indicadora do milho foi considerada baixa para o nitrogênio, fósforo, potássio, enxofre e magnésio; média para o cálcio, boro, ferro, manganês e alta para o cobre. Os coeficientes de correlação linear entre os atributos de nutrição mineral versus produtividade foram significativos e negativos para o cobre, manganês e zinco. Esses 
resultados estão diretamente ligados ao fornecimento anual desses micronutrientes juntamente com as adubações anuais e a média acidez do solo. A altitude mostrou ter uma relação mais direta com os atributos de nutrição mineral do milho do que os dados de produtividade. A análise estatística de correlação mostrou que há uma relação positiva entre os dados de altitude e produtividade. Em estudos de escala de campo normalmente não é possível isolar ou medir todos os fatores bióticos e abióticos que influenciam na produção da cultura. Entretanto, verificou-se que o conhecimento da variabilidade da nutrição mineral da planta e produtividade pode fornecer importantes subsídios na racionalização do uso de insumos.

\section{CORN PLANT NUTRIENT VARIABILITY IN AN HOMOGENEOUSLY MANAGED CROP FIELD}

\section{Summary}

The acquaintance on the variability of plant nutrition in cultivated areas may bring important subsidies for rationalizing the use of fertilizers and soil amenders. The objective of this case study was to determine the corn plant mineral nutrition variability through the fractionation of a commercially grown corn field into small management cells. The study was carried out in Alto Alegre farm in Planaltina, GO, Brazil, in a Typic Dystrarox soil under cerrado (savannah) in an area with 373 ha of corn crop grown during 2003/4 period. After outlining a polygon of area it was divided into 80 management cells of 4 ha each. The diagnostic leaf sampling followed a diagonal with twelve points where three leaves per each point were colleted from different plants to constitute a representative composite sample within each cell. The co-ordinates of these points were obtained and recorded. The leaf samples were analyzed for macro and micronutrients. The yield for each cell was obtained with harvester equipped with GPS and grain yield monitor. For data variability analysis the descriptive statistic parameters were considered. The variability of nutrient content in the diagnostic corn leaves were considered low for nitrogen, phosphorus, potassium, sulphur and magnesium content; 
medium for calcium, boron, iron, manganese; and high for copper. The linear correlation coefficients between the mineral nutrition versus grain yield were significants and negatives for copper, manganese and zinc. These results are directly linked with annual supplying of these micronutrients and medium soil acidity. The correlation of altitude with yield was positive, however the altitude showed to have more direct relationship with corn mineral nutrition than with yield data. The acquaintance on the variability of plant mineral nutrition and grain yield may provide important subsidies for rationalization on using farm inputs.

\subsection{Introdução}

A cultura do milho para produção de grãos utilizados na alimentação humana e animal vem aumentando a área plantada e a produtividade paulatinamente nas últimas décadas, assumindo um papel importante no agronegócio brasileiro, passando de um país importador para um país exportador de milho em grãos. Nesse contexto, por conseqüência do melhoramento genético realizado ao longo dos anos para obter alto potencial produtivo a planta tornou-se mais exigente em nutrientes. Assim, a nutrição mineral da cultura do milho assumiu um papel de suma importância no aumento da produtividade

Uma das formas de se aumentar a produtividade da cultura é, sem dúvida, a nutrição mineral adequada, através de programas de adubação que considerem, além da quantidade de fertilizantes fornecida, também o balanço entre os nutrientes requeridos, aliado a condições climáticas adequadas, principalmente em termos de precipitação pluviométrica (Büll, 1993).

A utilização da análise foliar como critério diagnóstico baseia-se na premissa de existir relação significativa entre o suprimento de nutrientes e os níveis dos elementos na folha, e que aumentos ou decréscimos nas concentrações se relacionam com produções mais altas ou mais baixas, respectivamente. Para o milho, a folha inteira oposta e abaixo da primeira espiga (superior), excluída a nervura central, coletada por ocasião do aparecimento da inflorescência feminina (embonecamento) é comumente utilizada para avaliar o estado nutricional dessa cultura. (Malavolta et al., 1997). A análise nesse 
estádio fisiológico é feita pelos seguintes motivos: a) o estádio de desenvolvimento e a posição da folha são facilmente reconhecidos; b) a remoção de uma simples folha não afeta a produção; c) o efeito de diluição dos nutrientes nessa fase é mínimo, pois o potencial de crescimento e armazenamento dos órgãos vegetativos atingiu o ponto máximo e, d) o requerimento de nutrientes é alto nessa fase.

Pela análise do material vegetal são quantificados os teores totais dos nutrientes, absorvidos pelas plantas, os quais dependem de vários fatores, tais como: teor no solo, acidez do solo, desenvolvimento do sistema radicular, antagonismo e sinergismo entre os nutrientes, variedade cultivada, condições climáticas, tipo de fertilizante empregado, atividade microbiana, mineralização da matéria orgânica, tratos culturais, incidência de doenças e pragas (Oliveira, 2004).

O conhecimento da variabilidade da nutrição mineral das plantas de milho e correlação com a produtividade em áreas consideradas e manejadas homogeneamente é fundamental para diagnosticar possíveis carências ou excessos de nutrientes na cultura, seja em locais específicos seja em área total. Este diagnóstico permite uma avaliação da resposta da cultura ás fertilizações realizadas e ao histórico de manejo da área considerada, além de esclarecer possíveis problemas ocasionados por diferentes fatores que influenciam na produtividade. A diagnose foliar pode ser considerada uma ferramenta complementar na interpretação dos dados de análise de solo.

Este trabalho teve por objetivo avaliar a variabilidade da nutrição mineral de plantas de milho por meio da análise foliar num talhão manejado homogeneamente e verificar possíveis relações com a produtividade da cultura do milho.

\subsection{Material e Métodos}

\subsubsection{Caracterização geral da área de estudo}

De 1987 a 1989, a área que estava sob vegetação natural de cerrado foi desmatada para o cultivo da soja. Após 1994, a área passou a ser cultivada em semeadura direta com a utilização do milho, além da soja. $O$ estudo de caso foi conduzido na Fazenda Alto Alegre localizada no município de Planaltina - GO, numa 
área de 373 hectares, cultivada com milho sequeiro na safra 2003/04. O solo da área foi classificado como Latossolo Vermelho-Amarelo.

A definição dos pontos e procedimento de amostragem do solo é descrita a seguir. O GPS Etrex Vista ${ }^{\circledR}$ foi utilizado para traçar uma poligonal da área. De posse do polígono procedeu-se divisão da área em 80 células de manejo de quatro hectares cada. As células das bordaduras foram desconsideradas para fins de amostragem. A amostragem seguiu uma diagonal com doze pontos para compor a amostra representativa, dentro de cada uma dos 80 células. As coordenadas desses pontos foram obtidas e arquivadas.

A dessecação da área foi realizada no período de $31 / 10$ a 05/11/2003 com $2,75 \mathrm{~L}$ $\mathrm{ha}^{-1}$ de glifosato $+0,6 \mathrm{~L} \mathrm{ha}^{-1}$ de 2,4-D amina. No período de 03 a 10/11/2003 realizou-se a semeadura direta com os híbridos 30F90, 30K75 e 3021 da Pioneer ${ }^{\circledR}$, com 64.000 sementes por hectare para obter uma população final de 60.000 plantas. As sementes foram tratadas com o inseticida Futur. O controle de invasoras foi realizado com aplicações em pré-emergência do herbicida Herbimix no período de 03/11 a 08/11/2003 Aplicou-se $330 \mathrm{~kg} \mathrm{ha}^{-1}$ como adubação de base no sulco de plantio usando a fórmula 08$28-16+\left(4,5 ; 2,5 ; 0,30 ; 0,08 ; 0,08 ; 0,15 \mathrm{~kg} \mathrm{ton}^{-1}\right.$ de $\mathrm{Ca}, \mathrm{S}, \mathrm{Zn}, \mathrm{B}, \mathrm{Cu}$ e $\mathrm{Mn}$, respectivamente). As adubações de cobertura foram realizadas com duas formulações. A primeira, no período de 18/11 a 01/12/2003, com a fórmula 22-00-20 à base de nitrato de amônio e cloreto de potássio na dosagem de $160 \mathrm{~kg} \mathrm{ha}^{-1}$ distribuído a lanço. A segunda, no período de 26/11 a 15/12/2003, com a fórmula 30-00-15 à base de uréia e cloreto de potássio na dosagem de $150 \mathrm{~kg} \mathrm{ha}^{-1}$ incorporado na entrelinha. Realizou-se uma aplicação de inseticida físiológico Galaxy para o controle da lagarta do cartucho em área total no período de 11 a $30 / 12 / 2003$.

\subsubsection{Análise química da planta}

A amostragem da folha indicadora foi realizada entre os dias 24 e 28/01/2004 nas coordenadas das subamostras do solo. A localização dos pontos foi feita com o uso GPS Etrex Vista ${ }^{\circledR}$. Foram coletadas 3 folhas por ponto de subamostra de plantas diferentes, 
totalizando 36 folhas por amostra composta. Foi colhido o terço médio da folha oposta e abaixo da espiga, no período do aparecimento da inflorescência feminina (cabelo), descartando-se a nervura central. (Malavolta et al., 1997)

O material vegetal (lâminas de folha) foi seco em estufa de circulação forçada de ar com temperatura constante ajustada a $65^{\circ} \mathrm{C}$ por um período de 48 horas. $\mathrm{O}$ material seco foi moído em moinho tipo Wiley, passando as amostras em peneira de 20 mesh. Para as determinações de macro e micronutrientes a exceção de $\mathrm{N}$ e $\mathrm{B}$, o material vegetal foi submetido à digestão nítrico-perclórica conforme descrito em Malavolta et al. (1997). No extrato nítrico-perclórico, a concentração de $P$ foi determinada por espectrofotometria do metavanadato + molibdato, a de potássio $(\mathrm{K})$ por fotometria de emissão de chama, as concentrações de $\mathrm{Ca}, \mathrm{Mg}, \mathrm{Cu}, \mathrm{Fe}, \mathrm{Mn}$ e $\mathrm{Zn}$ por espectrometria de absorção atômica e a de $\mathrm{S}$ por turbidimetria do sulfato de bário. Para a determinação de $\mathrm{N}$, submeteu-se o material vegetal à digestão sulfúrica e posterior destilação do extrato pelo método micro-Kjeldahl. O extrato vegetal para determinação da concentração de $B$ foi obtido pela incineração do material seco com posterior leitura pelo método espectrofotométrico da azometina.

\subsubsection{Obtenção dos dados de produtividade}

Os dados de produtividade do talhão foram obtidos no momento da colheita do milho, por meio de colhedora New Holland TC 59 equipada com Sistema de Posicionamento Geográfico (GPS), sensor de fluxo de grãos por placa de impacto, sensor de umidade de grãos, sensor de velocidade de deslocamento da colhedora e sensor de controle de altura da plataforma. Essas informações foram gerenciadas pelo monitor de rendimento de grãos AgLEADER PFAdvantage ${ }^{\circledR}$, que fez as leituras de produtividade, altitude e umidade de grãos a cada dois segundos, durante a colheita da cultura em toda a área.

O Sistema de Informação Geográfica (SIG) ArcView foi utilizado para a visualização dos dados brutos de produtividade de grãos e altitude. A partir desses dados pode-se fazer a interpolação, pelo método do inverso do quadrado da distância. 
A obtenção dos dados médios de produtividade e altitude, para cada uma das 80 células de manejo, foi realizado pelo SIG. Foram sobrepostos os pontos georefernciados das subamostras do solo e os mapas de dados brutos de produtividade e altitude. Em cada ponto de subamostra, foram selecionados os dados de produtividade e altitude, contidos em um círculo com $10 \mathrm{~m}$ de raio, criado pelo programa utilizando-se a ferramenta "Select Feature". Esses dados selecionados serviram para obter os dados médios de cada uma das 80 células de manejo.

\subsubsection{Análise estatística}

$\mathrm{Na}$ análise estatística dos resultados, foi considerado o cálculo dos parâmetros estatísticos referentes às medidas de tendência central e variabilidade, para cada conjunto de valores. Foram calculados os coeficientes de assimetria e curtose, para se inferir sobre o tipo e o formato da curva de distribuição dos resultados de cada atributo do solo. Os resultados da análise estatística descritiva foram apresentados também, na forma de histogramas de freqüências, retas de probabilidade normal e gráficos de boxplot. O histograma de freqüências, trás como complemento o resultado do teste nãoparamétrico de Kolmogorov-Smirnov, com o objetivo de verificar a normalidade da distribuição. A análise de regressão linear simples foi realizada para analisar uma possível relação direta entre os atributos de nutrição mineral do milho e os dados de produtividade e altitude da área, nas células de manejo.

\subsection{Resultados e Discussão}

\subsubsection{Macronutrientes}

$\mathrm{Na}$ Tabela 8 estão apresentados os parâmetros estatísticos descritivos para as concentrações dos macronutrientes na folha indicadora do milho que serão discutidos na seqüência. 
Tabela 8. Parâmetros estatísticos descritivos para as concentrações dos macronutrientes na folha das plantas de milho cultivadas sob sequeiro

\begin{tabular}{lcccccc}
\hline Parâmetros Avaliados & $\mathrm{N}$ & $\mathrm{P}$ & $\mathrm{K}$ & $\mathrm{Ca}$ & $\mathrm{Mg}$ & $\mathrm{S}$ \\
\hline & $-\cdots-\cdots$ & & & \\
№ de amostras & 80 & 80 & 80 & 80 & 80 & 80 \\
Média & 31,00 & 2,43 & 23,97 & 5,07 & 2,08 & 2,07 \\
Mediana & 30,63 & 2,44 & 23,40 & 4,90 & 2,09 & 2,02 \\
Mínimo & 28,60 & 2,03 & 21,83 & 4,10 & 1,61 & 1,82 \\
Máximo & 37,43 & 3,05 & 32,31 & 7,65 & 2,74 & 3,68 \\
Quartil inferior & 30,11 & 2,28 & 22,87 & 4,66 & 1,92 & 1,96 \\
Quartil superior & 31,47 & 2,52 & 24,45 & 5,19 & 2,23 & 2,10 \\
Amplitude & 8,83 & 1,02 & 10,48 & 3,55 & 1,13 & 1,86 \\
Variância & 2,72 & 0,04 & 5,22 & 0,53 & 0,06 & 0,06 \\
Desvio Padrão & 1,65 & 0,19 & 2,29 & 0,73 & 0,24 & 0,25 \\
CV(\%) & 5,32 & 7,89 & 9,53 & 14,38 & 11,31 & 11,87 \\
Assimetria & 1,76 & 0,63 & 2,28 & 2,12 & 0,25 & 4,64 \\
Curtose & 4,23 & 1,24 & 5,04 & 4,63 & 0,12 & 26,32 \\
\hline
\end{tabular}

\subsubsection{Nitrogênio}

A média e mediana, para as concentrações de $\mathrm{N}$, apresentam valores diferentes, portanto, a distribuição não tende à normal. Pelo coeficiente de assimetria observamos que a distribuição dos valores deste nutriente é fortemente assimétrica. Como este valor é positivo pode-se inferir que a curva de distribuição apresenta assimetria positiva, ou seja, com uma freqüência maior de valores abaixo do valor médio. $O$ valor do coeficiente de curtose, trás a informação de que a curva é do tipo leptocúrtica, diga-se de passagem, com um valor elevado para o coeficiente.

A variabilidade nas concentrações de $\mathrm{N}$ foi baixa, pois o $\mathrm{CV}$, da ordem de $5,3 \%$, é considerado baixo segundo o critério de Warrick \& Nielsen (1980). A dispersão dos resultados de $\mathrm{N}$ é razoavelmente alta, devido aos valores de variância e desvio padrão, 
maiores em comparação com aqueles calculados para a maioria dos macronutrientes na folha. Analisando exclusivamente a relação entre a magnitude do $\mathrm{CV}$ e do tipo de distribuição de freqüência, que neste caso não foi proporcional, fica em desacordo com Salviano et al. (1998), Oliveira et al. (1999) e Carvalho et al. (2003), que verificaram correlação diretamente proporcional entre os dois parâmetros estatísticos para os atributos do solo. Infere-se que a distribuição assimétrica é influenciada pela presença de valores discrepantes.

Na Figura 10 estão apresentados o histograma de freqüência, a reta de probabilidade normal e o gráfico de "Box-plot", para as concentrações foliares de $\mathrm{N}$. Verifica-se pela curva de distribuição no histograma de freqüência, uma forte assimetria à direita, como sugeriu os parâmetros da estatística de posição. Não há um bom ajuste dos pontos a reta de distribuição normal, mostrando que para o conjunto das concentrações de $\mathrm{N}$, o comportamento dos valores não pode ser explicado por uma curva Gaussiana. O gráfico de "Box-plot", mostra de maneira mais visível a forte assimetria que apresenta o conjunto de resultados para esta variável. Observa-se que a faixa de concentração compreendida entre o quartil inferior e o quartil superior, ou seja, $50 \%$ dos resultados, é bastante estreita.

$\mathrm{Na}$ média a concentração de $\mathrm{N}$, para as amostras foliares da área considerada neste estudo, está contida na faixa adequada segundo Oliveira (2004). O valor mínimo para a concentração de $\mathrm{N}$, da ordem de $28,6 \mathrm{~g} \mathrm{~kg}^{-1}$, mostra que as plantas estão bem nutridas neste macronutriente. Em três amostras as concentrações foram elevadas, ou seja, acima de $35,0 \mathrm{~g} \mathrm{~kg}^{-1}$, sendo que uma corresponde ao valor máximo determinado. Os resultados destas amostras são fortes candidatos a valores atípicos, pelo ajuste desses em relação à reta de probabilidade normal (Figura 10). 


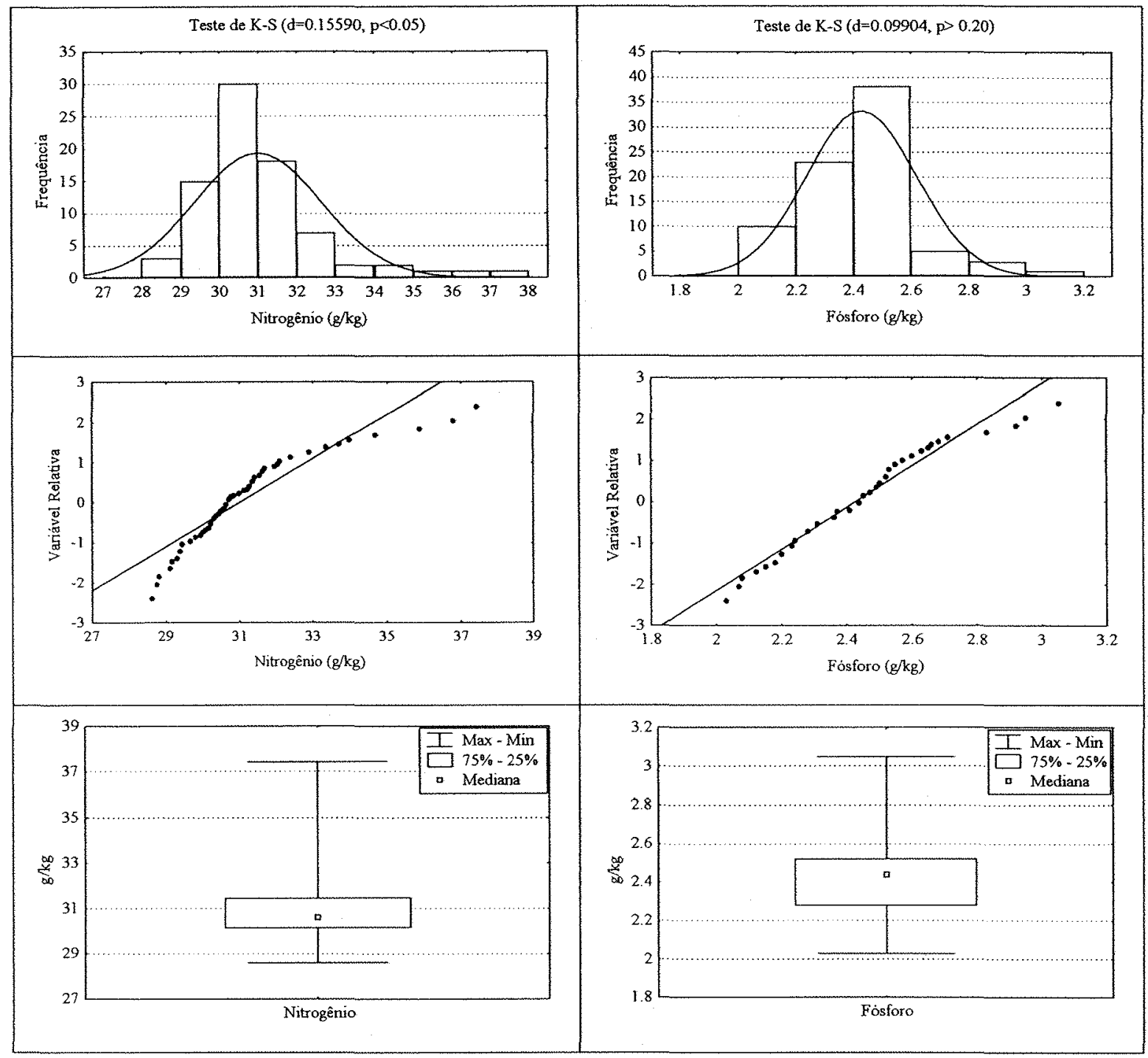

Figura 10 - Histogramas de freqüência, retas de probabilidade normal e gráficos de "Box-plot" para as concentrações de nitrogênio e fósforo

\subsubsection{Fósforo}

Verifica-se que o P na folha tende a uma distribuição normal (Tabela 8), pois os valores da média e mediana para o conjunto das concentrações são praticamente iguais. Também, o valor do coeficiente de assimetria está próximo a zero, o que caracteriza uma distribuição simétrica. O coeficiente de curtose positivo indica que o formato da curva de distribuição é do tipo leptocurtica, portanto, no conjunto de resultados para o $\mathrm{P}$ na 
planta há uma concentração de valores dentro de uma determinada faixa, o que contradiz a interpretação dos resultados dos parâmetros estatísticos, anteriormente comentados.

O CV mostra que a concentração de $\mathrm{P}$ nas folhas de milho, tem uma baixa variabilidade, pois o valor foi da ordem de $7,8 \%$. Entretanto, a variabilidade deste nutriente é maior que a encontrada para o $\mathrm{N}$. Verifica-se que a dispersão do fósforo é muito pequena, o que pode ser confirmado pelo valor da variância, que é aproximadamente nulo.

$\mathrm{Na}$ Figura 10 pode-se visualizar, para as concentrações de $\mathrm{P}$ na folha, o histograma de freqüência, a reta de probabilidade normal e o gráfico de "Box-plot". No histograma de frequiência, observa-se que os valores de $\mathrm{P}$ tendem a distribuição normal, principalmente no lado direto do gráfico, o que pode ser facilmente visualizado. A representatividade de valores de concentração acima de $2,6 \mathrm{~g} \mathrm{~kg}^{-1}$ é muito baixo, o que é visualizado no lado esquerdo do gráfico. Portanto, o conjunto dos resultados de $\mathrm{P}$ apresenta uma pequena assimetria. Este comportamento é visualizado melhor no gráfico de "Box-plot". Onde também observa que o valor da mediana não coincide com o centro da caixa, como poderia se supor pela igualdade entre os valores da média e mediana (Tabela 8). $\mathrm{O}$ ajuste dos pontos a reta de probabilidade foi melhor do que em relação aos resultados de $\mathrm{N}$.

Segundo a faixa de concentração adequada de $\mathrm{P}$ para a cultura do milho no Cerrado, apresentada por Oliveira (2004), observa-se que no geral as plantas estão bem supridas de P. Dentre os macronutrientes o P é extraído em pouca quantidade pelas plantas. Phillips \& Lessman (1972), mostram que para altas produtividades, o P é o penúltimo macronutriente mais extraído, perdendo apenas para o S. Em compensação é o terceiro macronutriente mais exportado, segundo classificação encontrada em Büll (1993), sendo que, $80 \%$ do P extraído estão contidos nos grãos.

\subsubsection{Potássio}

A diferença entre a média e mediana, para as concentrações de $\mathrm{K}$, indica que, o comportamento do elemento nas folhas de milho, não pode ser explicado por uma curva de distribuição normal. $O$ coeficiente de assimetria mostra que não é simétrica a 
distribuição, pelo fato deste valor ser bem diferente de zero. Esse coeficiente positivo indica que as concentrações de $\mathrm{K}$ seguem uma curva deslocada à direita da concentração média. O formato da curva de distribuição é do tipo leptocurtica, devido ao alto valor positivo do coeficiente de curtose.

A variabilidade das concentrações de $\mathrm{K}$ é baixa, pois o resultado do $\mathrm{CV}$ foi da ordem de 9,6\%, levando-se em consideração a classificação proposta por Warrick e Nielsen (1980). As medidas estatísticas de variância e desvio padrão foram maiores no caso das concentrações de $\mathrm{K}$ do que em relação aos outros macronutrientes. Esta comparação só é permitida, pois esses atributos possuem a mesma unidade de medida, não sendo, a variância e o desvio padrão, medidas relativas de variabilidade. Assim, a dispersão e a amplitude total para o K é maior em comparação com os macronutrientes determinados na planta.

O histograma de freqüência, a reta de probabilidade normal e o gráfico de "Boxplot", construídos a partir das concentrações de $\mathrm{K}$ no tecido foliar das plantas de milho, podem ser visualizados pela Figura 11. Observa-se por meio do histograma de frequiência, que um pequeno subconjunto de valores se afasta das demais concentrações. Pode-se supor ser um grupo de valores atípicos que estão influenciando, de forma negativa, a variabilidade dos resultados e no ajuste das concentrações a distribuição normal. Na reta de probabilidade, observa-se a falta de ajuste dos pontos em relação à reta e a presença de três pontos, que são possíveis candidatos a valores discrepantes. $\mathrm{O}$ gráfico de "Box-plot" mostra bem visualmente a assimetria acentuada na distribuição das concentrações de K. Destaca-se a elevada dispersão dos resultados acima do quartil superior.

Não foi verificada limitação nutricional de $\mathrm{K}$ nesta área de estudo durante o cultivo do milho, pois a concentração mínima determinada está acima do limite inferior adequado para a cultura do milho no Cerrado (Oliveira, 2004). Pode-se observar pelo histograma de freqüência (Figura 11) que algumas amostras apresentaram concentrações acima de $30 \mathrm{~g} \mathrm{~kg}^{-1}$, que é o limite superior para da faixa de concentração adequada para o K. Como discutido no parágrafo anterior, estes valores de concentração se afastam das concentrações de $\mathrm{K}$ das demais amostras. 


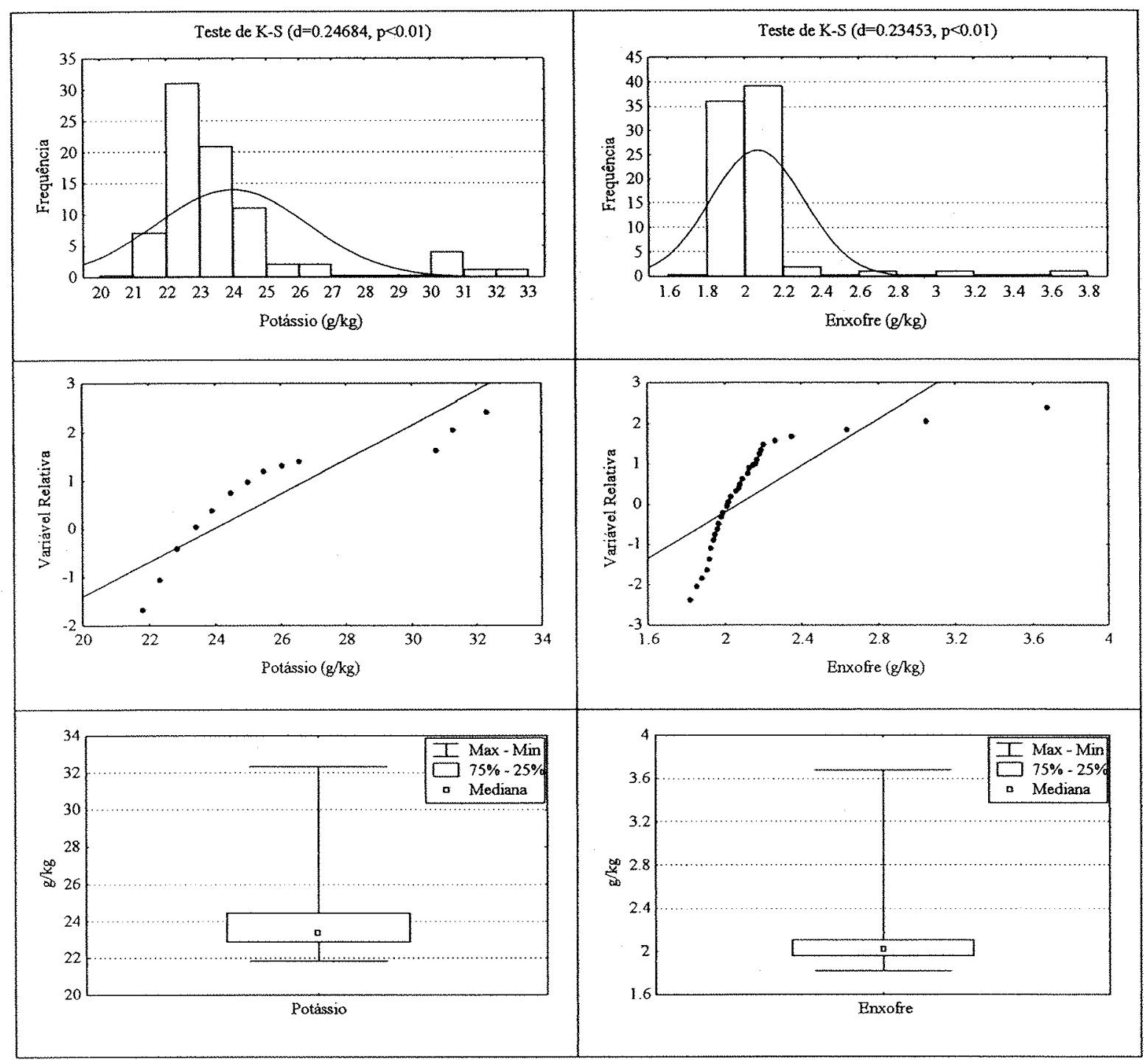

Figura 11 - Histogramas de freqüência, retas de probabilidade normal e gráficos de "Box-plot" para as concentrações de potássio e enxofre

\subsubsection{Enxofre}

Pode-se observar, pela Tabela 8, que os resultados de $\mathrm{S}$ na planta tendem a curva de distribuição normal, pois a média e mediana apresentam valores próximos um do outro. É contraditória esta afirmação quando se observa o valor do coeficiente de assimetria, que para este caso, demonstra uma distribuição fortemente assimetria. $\mathrm{O}$ 
valor calculado do coeficiente de curtose indica que a curva de distribuição possui o formato leptocurtica bem caracterizada devido ao elevado valor do coeficiente.

$\mathrm{O}$ valor do $\mathrm{CV}$ para as concentrações de $\mathrm{S}$ determinadas na folha está bem próximo ao limite superior relativo a classe de baixa variabilidade, segundo critério proposto por Warrick \& Nielsen (1980). Mostrando que a variabilidade deste elemento também pode ser considerada pequena. Também foi baixa a dispersão dos valores de enxofre, como demonstra as medidas estatísticas de variância e desvio padrão.

A análise estatística apresentada, através do histograma de freqüência, reta de probabilidade normal e gráfico de "Box-plot" são visualizadas na Figura 11. No histograma de frequiência fica evidente a não normalidade dos resultados de S. Também observa-se a forte assimetria da curva de distribuição e a presença de possíveis candidatos a valores discrepantes. Estes valores discrepantes são visualizados na reta de probabilidade normal, como sendo três pontos que não se ajustam os demais pontos em relação à reta. No gráfico de "Box-plot" nota-se novamente a forte assimetria da distribuição e a elevada dispersão das concentrações acima do quartil superior. Isto contradiz o que foi interpretado pelas medidas de variância e desvio padrão.

Para o $\mathrm{S}$ as concentrações estão contidas dentro da faixa adequada para a cultura do milho no Cerrado (Oliveira, 2004). Vale ressaltar que o $S$ é o macronutriente menos extraído pela planta ficando atrás inclusive do P. Porém $58 \%$ do S é exportado pelos grãos da cultura (Büll, 1993).

\subsubsection{Cálcio}

Os valores da média e mediana, para as concentrações de $\mathrm{Ca}$, indicam que a distribuição não tende a normal, pois os resultados dessas medidas de tendência central são diferentes. $O$ valor do coeficiente de assimetria demonstra uma curva assimétrica que representa a distribuição do conjunto. O resultado para o coeficiente de curtose indica que a curva de distribuição é do tipo leptocurtica.

As concentrações de $\mathrm{Ca}$ apresentam a maior variabilidade, em comparação aos demais macronutrientes analisados, devido o fato do valor do CV estar contido dentro da classificação de média variabilidade, para os atributos que apresentam CV entre 12 e 
52\% (Warrick \& Nielsen, 1980). As concentrações de Ca na folha, por outro lado, apresentaram uma baixa dispersão dos valores em torno da média, pois os parâmetros estatísticos de variância e desvio padrão tiveram valores relativamente baixos, em comparação com os macronutrientes $\mathrm{N}$ e K.

$\mathrm{Na}$ Figura 12 está apresentado o histograma de freqüência, a reta de probabilidade normal e o gráfico de "Box-plot", para as concentrações de Ca. Nota-se pelo histograma de freqüência o que se observou para as concentrações de $K$, ou seja, um pequeno subgrupo de valores afastados dos demais. Assim, para a análise da distribuição dos valores de $\mathrm{Ca}$ pode-se supor a presença de valores discrepantes influenciando o não ajuste dos pontos em relação a reta de probabilidade normal. Observa-se que a dispersão dos pontos para o conjunto das concentrações de $\mathrm{K}$ e Ca nas folhas é muito parecida nos dois casos, principalmente na extremidade superior da reta, onde se visualiza os valores discrepantes. Na reta de probabilidade normal para as concentrações de $\mathrm{N}$ há uma tendência de seguir a mesma dispersão dos pontos para o $\mathrm{K}$ e Ca. Muito parecidos também são os gráficos de "Box-plot" para o conjunto dos resultados de $\mathrm{N}, \mathrm{K}$ e Ca nas folhas, podendo-se visualizar em todos a elevada dispersão acima do quartil superior.

Todas as concentrações de Ca determinadas nas folhas estão contidas na faixa de concentração adequada para o elemento no Cerrado (Oliveira, 2004). 


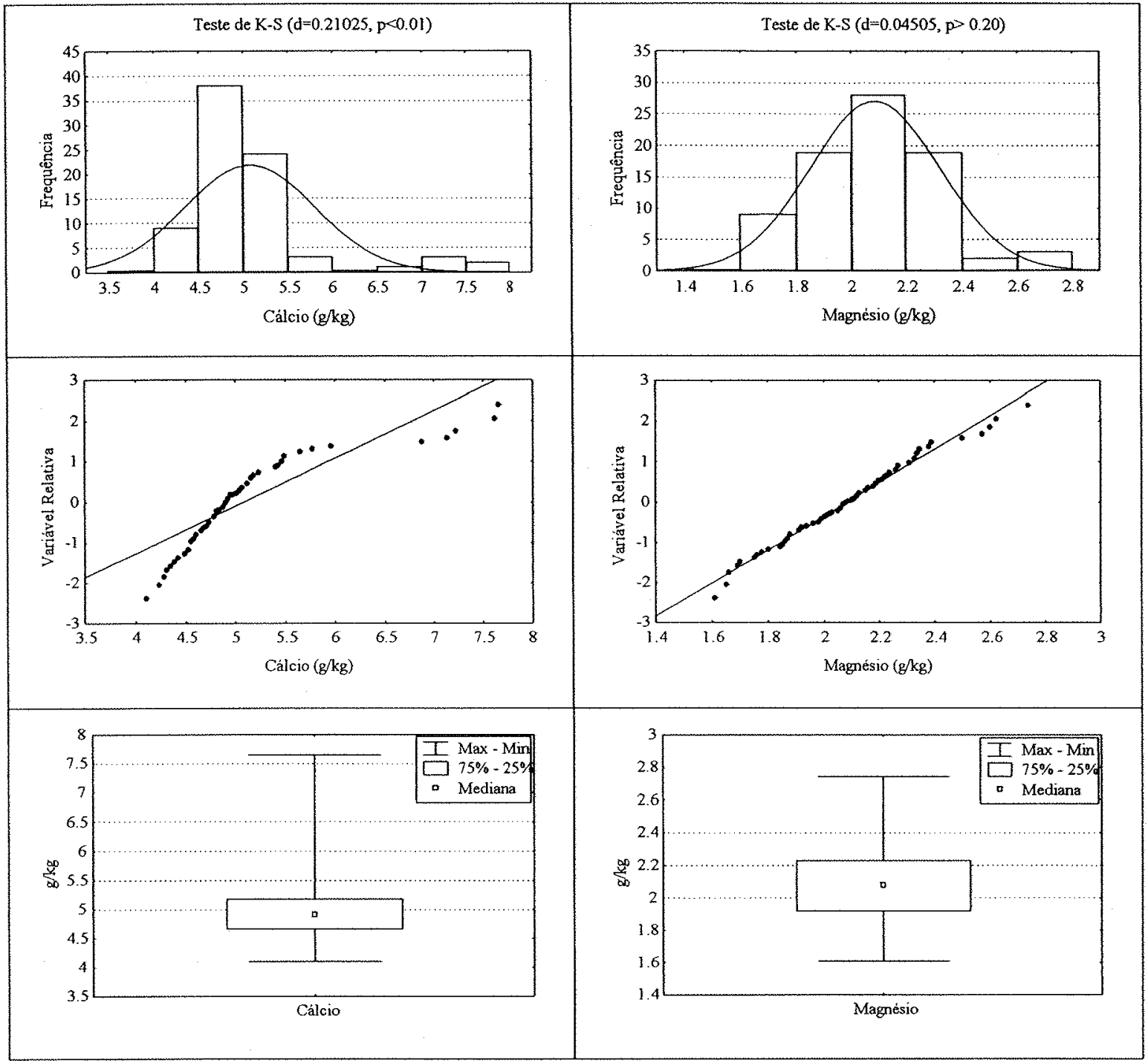

Figura 12 - Histogramas de frequêencia, retas de probabilidade normal e gráficos de "Box-plot" para as concentrações de cálcio e magnésio

\subsubsection{Magnésio}

Os valores de $\mathrm{Mg}$ determinados na folha tendem a uma distribuição normal, como demonstra os resultados de média e mediana. O resultado do coeficiente de assimetria corrobora para esta afirmação, apresentando um valor próximo a zero indicando que o conjunto das concentrações de $\mathrm{Mg}$ é simetricamente distribuído. $\mathrm{O}$ baixíssimo valor para o coeficiente de curtose mostra que o formato da curva de 
distribuição assemelha-se ao formato típico de uma distribuição normal, ou seja, do tipo mesocurtica.

A variabilidade baixa para as concentrações de $\mathrm{Mg}$ na folha é verificada pelo baixo valor do CV, segundo a classificação de Warrick \& Nielsen (1980). Observa-se também que a dispersão dos valores de $\mathrm{Mg}$ é muito baixa, pois os resultados calculados para as medidas de variância e desvio padrão demonstram isto. Pode-se verificar uma baixa amplitude das concentrações do elemento nas folhas. Assim, o $\mathrm{P}$ e o Mg são, dentre os macronutrientes analisados, os que apresentaram a menor dispersão em suas concentrações.

A Figura 12 mostra as representações do histograma de frequiência, a reta de probabilidade normal e o gráfico de "Box-plot", para as concentrações de $\mathrm{Mg}$. Pode-se visualizar pelo histograma a tendência dos valores de $\mathrm{Mg}$ em seguir a curva de distribuição normal. $O$ que também mostra o resultado do teste não-paramétrico de Kolmogorov-Smirnov. Sendo este significativo para a hipótese de distribuição normal dos valores, em todos os níveis de significância ( $p>0.20)$. Observa-se o bom ajuste dos pontos em relação à reta de probabilidade normal, ficando um pouco prejudicado nas extremidades da reta. A análise visual das retas de probabilidade, para o $\mathrm{Mg}$ e o $\mathrm{P}$, mostra uma tendência de não ajuste dos pontos na mesma região do gráfico. Relembrando o que foi visto para o N, K e Ca, supõe-se novamente influência de valores atípicos, porém menos evidente no caso do $\mathrm{P}$ e $\mathrm{Mg}$. O gráfico de "Box-plot" possui uma certa semelhança com o mesmo gráfico para as concentrações de P. Como era de se esperar, pois o comportamento destes dois conjuntos de valores foi comprovadamente parecido pela análise dos parâmetros estatísticos descritivos.

Do mesmo modo que as concentrações de $\mathrm{Ca}$, as de $\mathrm{Mg}$ apresentaram valores dentro da faixa adequada de concentração apresentada por Oliveira (2004), sem exceção. $\mathrm{O} \mathrm{Mg}$ foi o único dos macronutrientes cujos resultados possuem uma distribuição próxima a normal. 


\subsubsection{Micronutrientes}

Na tabela 9 estão apresentados os parâmetros estatísticos descritivos para as concentrações dos micronutrientes na folha indicadora do milho que serão discutidos na seqüiência.

Tabela 9. Parâmetros estatísticos descritivos para as concentrações dos micronutrientes na folha das plantas de milho cultivadas sob sequeiro

\begin{tabular}{lccccc}
\hline \multicolumn{1}{c}{ Parâmetros Avaliados } & B & Cu & Fe & Mn & Zn \\
\hline NNo de amostras & $-\cdots$ & 80 & 80 & 80 & 80 \\
Média & 80 & 8,04 & 114,37 & 30,92 & 40,65 \\
Mediana & 3,81 & 7,60 & 106,77 & 30,28 & 38,57 \\
Mínimo & 2,43 & 4,22 & 78,78 & 24,44 & 26,36 \\
Máximo & 5,79 & 12,81 & 222,78 & 43,35 & 62,47 \\
Quartil inferior & 3,36 & 6,43 & 88,44 & 28,17 & 33,96 \\
Quartil superior & 4,11 & 9,84 & 127,04 & 32,78 & 46,97 \\
Amplitude & 3,36 & 8,59 & 144,00 & 18,91 & 36,11 \\
Variância & 0,41 & 5,41 & 997,99 & 16,74 & 78,66 \\
Desvio Padrão & 0,64 & 2,33 & 31,59 & 4,09 & 8,87 \\
CV(\%) & 16,80 & 28,95 & 27,62 & 13,23 & 21,82 \\
Assimetria & 0,52 & 0,45 & 1,23 & 1,05 & 0,67 \\
Curtose & 0,49 & $-0,71$ & 1,18 & 0,93 & $-0,66$ \\
\hline
\end{tabular}

Se a meta a ser atingida na cultura do milho é uma produtividade elevada, os micronutrientes passam a ser de fundamental importância nos dias atuais. Essa importância é maior principalmente em solos intensivamente cultivados, nos quais as reservas destes nutrientes se encontram esgotadas, e nos solos geneticamente pobres das regiões do Cerrado (Büll, 1993). Com relação aos micronutrientes a cultura do milho 
tem baixa sensibilidade à deficiência de $\mathrm{B}$, media sensibilidade a de $\mathrm{Cu}, \mathrm{Fe}$ e Mn e alta à deficiência de Zn (Martens \& Wertermann, 1991).

\subsubsection{Boro}

A média e a mediana para as concentrações de $\mathrm{B}$ nas folhas de milho possuem valores relativamente próximos entre si, indicando que o conjunto dos resultados para o $B$ apresenta uma tendência a distribuição normal. O coeficiente de assimetria indica distribuição simétrica devido ao seu valor próximo de zero. O valor do coeficiente de curtose mostra que a curva de distribuição é do tipo mesocurtica, ou seja, acompanha a distribuição normal dos resultados.

Pelo resultado do $\mathrm{CV}$, pode-se afirmar que o conjunto das concentrações de $\mathrm{B}$ possui uma variabilidade média, segundo o critério de Warrick \& Nielsen (1980). As concentrações deste nutriente apresentaram uma baixa dispersão, devido o fato dos resultados de variância e desvio padrão, terem sido os menores valores, em comparação com as medidas de variabilidade calculadas para os demais micronutrientes.

Na Figura 13 estão apresentados o histograma de freqüência, a reta de probabilidade normal e o gráfico de "Box-plot", para as concentrações de B. Muito do que se comentou no primeiro parágrafo deste item, pode ser visualizado pelo histograma de freqüências, onde se nota a presença de um distribuição bem próxima da normal. Esta afirmação é verificada pela reta de probabilidade normal, em que há um bom ajuste dos pontos em relação à reta. O gráfico de "Box-plot" mostra uma certa assimetria para os valores de $\mathrm{B}$, devido provavelmente a não coincidência entre as medidas de tendência central, como a média é bastante influenciada pela presença de valores discrepantes, pode-se inferir que seu valor está distorcido provavelmente pelo ponto na reta de probabilidade normal que não se ajustou perfeitamente. Observa-se a maior dispersão que ocorre acima do quartil superior no gráfico de "Box-plot", onde estão concentrados $25 \%$ dos resultados.

As concentrações de B estão abaixo da faixa adequada para a cultura do milho no Cerrado (Oliveira, 2004), mostrando que há uma deficiência generalizada desse micronutriente na área de estudo. Porém, como mencionado anteriormente, a cultura do 
milho tem baixa sensibilidade a deficiência de B (Martens \& Wertermann, 1991). O B é muito afetado pelo $\mathrm{pH}$, pela textura do solo e pelo teor de $\mathrm{Ca}$. A valores de $\mathrm{pH}$ mais elevados o elemento se torna menos disponível. Solos mais argilosos adsorvem mais o B e podem, assim, dificultar a absorção pelas plantas (Raij, 1991).

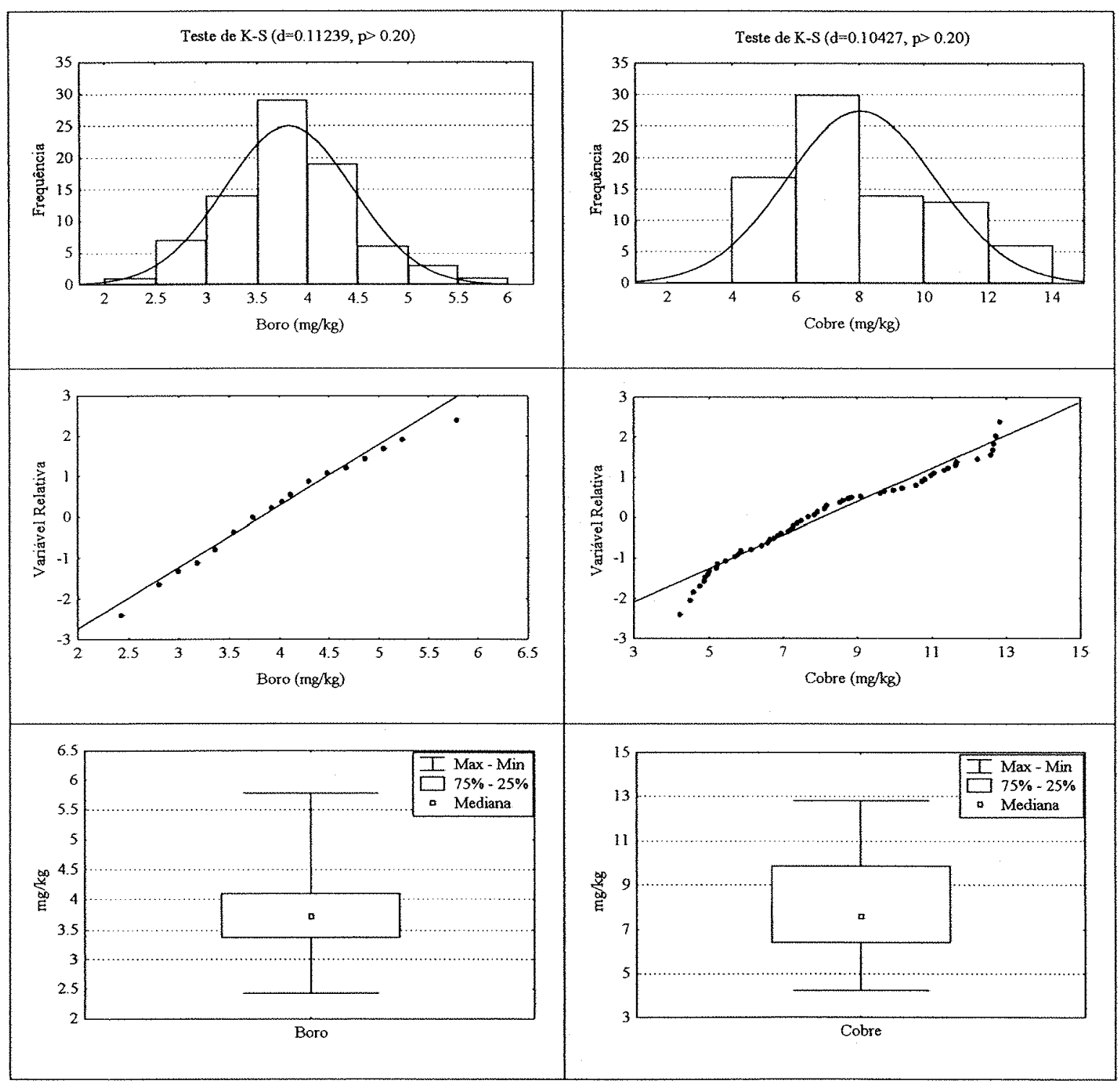

Figura 13 - Histogramas de freqüência, retas de probabilidade normal e gráficos de "Box-plot" para as concentrações de boro e cobre 


\subsubsection{Cobre}

Observa-se que a distribuição das concentrações de $\mathrm{Cu}$ não tende a normal, pois há uma diferença considerável entre os valores de média e mediana. Porém pode-se dizer que o conjunto tende a uma distribuição simétrica, devido ao valor do coeficiente de assimetria estar próximo de zero. O valor negativo do coeficiente de curtose indica que a curva de distribuição possui o formato que tende ao tipo platicurtica.

A variabilidade para as concentrações de $\mathrm{Cu}$ foi elevada, comparativamente ao outros atributos de nutrição mineral do milho, pois o CV apresentou o maior valor em relação aos $\mathrm{CV}$ calculados para os demais nutrientes na planta. Porém, assim como os demais micronutrientes, a variabilidade das concentrações de $\mathrm{B}$ foi classificada como média, pelo mesmo critério seguido para todos os atributos.

Pela Figura 13 visualiza-se o histograma de freqüência, a reta de probabilidade normal e o gráfico de "Box-plot", para as concentrações de $\mathrm{Cu}$. No histograma, a distribuição dos resultados de $\mathrm{Cu}$ segue uma distribuição assimetria positiva. Fica claro que a confecção do histograma de freqüência ajuda a definir melhor a distribuição do conjunto de resultados, do que apenas a verificação dos valores tabelados da estatística descritiva. Pode-se observar, também que há uma razoável flutuação dos pontos em relação à reta de probabilidade normal, principalmente nas extremidades da reta. No gráfico de "Box-plot" se nota uma certa simetria na distribuição dos resultados de $\mathrm{Cu}$, como mostrou o valor do coeficiente de assimetria (Tabela 9), porém com um distanciamento da mediana em relação ao ponto que representa a média dos valores de $\mathrm{Cu}$.

Pode-se verificar que mais de $75 \%$ dos resultados das concentrações de Cu estão acima de $6,0 \mathrm{mg} \mathrm{kg}^{-1}$, que é o limite inferior para a faixa adequada, apresentada por Oliveira (2004) para a cultura do milho no Cerrado. Em termos médios as plantas se encontram bem supridas por $\mathrm{Cu}$. Estudos conduzidos com a cultura milho em solos originalmente sob vegetação de Cerrado e em solos de várzea não mostraram efeitos positivos da aplicação de Cu (Büll, 1993). 


\subsubsection{Ferro}

A diferença entre o valor médio e a mediana, para as concentrações de Fe, indica que para este conjunto a distribuição não se aproxima da normal. O elevado valor do coeficiente de assimetria demonstra que a maioria das concentrações de Fe se concentra abaixo do valor médio. $O$ valor diferente de zero e positivo para o coeficiente de curtose demonstra que a curva de distribuição é do tipo leptocurtica, reforçando o que foi mencionado acima de que há uma aglomeração de resultados em uma certa faixa estreita, em relação a amplitude de valores de concentração.

A variabilidade das concentrações deste elemento está contida dentro da classificação média, segundo o critério proposto por Warrick \& Nielsen (1980). Nota-se o alto valor da amplitude total para as concentrações de Fe. Os valores de variância e desvio padrão ajudam a afirmar sobre a elevada dispersão dos resultados deste micronutriente para a área de estudo.

O histograma de frequiência, a reta de probabilidade normal e o gráfico de "Boxplot", para os resultados das concentrações de Fe, podem ser visualizados pela Figura 14. No histograma de freqüência há uma forte assimetria positiva para as concentrações de Fe, sendo mais evidente através da visualização do gráfico de "Box-plot". Na reta de probabilidade normal, o ajuste dos pontos é deficiente, sobretudo na extremidade inferior da reta. No gráfico de "Box-plot", nota-se a grande dispersão que há nas concentrações acima do valor médio. As concentrações abaixo da média apresentam uma alta frequêencia. Portanto tem-se uma forte assimetria na distribuição destes resultados.

$\mathrm{O}$ amplo intervalo de valor nas concentrações de $\mathrm{Fe}$, que define a faixa adequada para a cultura do milho no Cerrado, garante que todos os resultado determinados nas amostras de folha, estejam contidos dentro desta faixa. Não existem trabalhos na literatura brasileira, mostrando a resposta do milho à aplicação de Fe, chegando inclusive a ocorrer, segundo alguns autores, aumento na produção de biomassa quando da omissão deste em relação ao tratamento completo (Büll, 1993). A capacidade das plantas em absorver Fe parece estar condicionada ao tipo de solo, mais especificamente a cor do solo. 

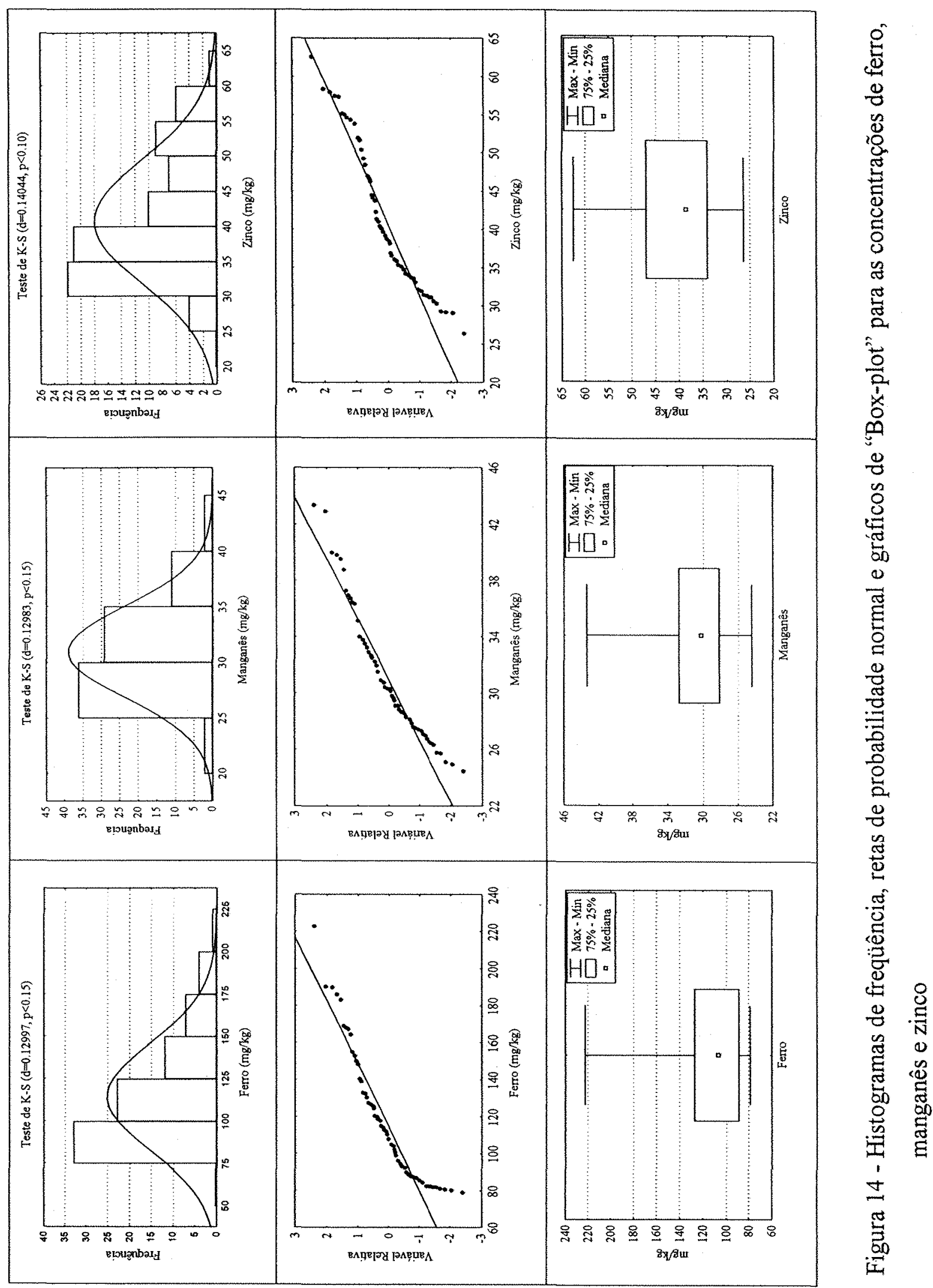


\subsubsection{Manganês}

Na Tabela 9 nota-se certa proximidade entre os valores da média e mediana, mostrando que as concentrações de $\mathrm{Mn}$ na folha podem tender a uma distribuição normal. O resultado para o coeficiente de assimetria, contudo, mostra que a distribuição para este conjunto apresenta uma certa assimetria. $O$ valor do coeficiente de curtose indica que a curva de distribuição é do tipo leptocurtica, o que não caracteriza uma distribuição próxima da normal.

$\mathrm{O} \mathrm{CV}$ para as concentrações de $\mathrm{Mn}$ foi o menor dentre todos os outros coeficientes calculados para os micronutrientes. Porém o $\mathrm{Mn}$, assim como os outros micronutrientes, apresentam variabilidade classificada como média segundo critério de Warrick \& Nielsen (1980). Os valores de variância e desvio padrão são elevados, mostrando uma dispersão nos resultados das concentrações de Mn, porém menor que a dispersão para as concentrações de Fe e Zn

A Figura 14 mostra o histograma, a reta de probabilidade normal e o gráfico de "Box-plot" para as concentrações de Mn. Observa-se pelo histograma de freqüência que as concentrações apresentam uma distribuição assimétrica positiva. $\mathrm{O}$ ajuste dos pontos, em relação à reta de probabilidade normal, é deficiente nas extremidades da mesma. Nota-se, a partir da reta de probabilidade normal, a presença de pontos na extremidade superior da reta contribuindo para a assimetria nas concentrações de Mn. O gráfico de "Box-plot" mostra mais claramente a assimetria para o conjunto. Nota-se a maior dispersão das concentrações acima do quartil superior.

Existe um amplo intervalo de concentrações para $\mathrm{Mn}$, assim como no caso do Fe, contidas dentro da faixa adequada apresentada por Oliveira (2004), para a cultura do milho no Cerrado. Em termos médios, a concentração de Mn determinada nas amostras coletadas na área de estudo, está abaixo da faixa de adequada nutrição mineral da cultura, com relação ao elemento. A semelhança do Fe, ocorrências de deficiência de manganês na cultura do milho praticamente inexistem, havendo maiores problemas de toxidade (Büll, 1993). 


\subsubsection{Zinco}

As concentrações de $\mathrm{Zn}$ nas amostras foliares de milho não possuem tendência a uma distribuição normal. Primeiramente, porque o valor da média e da mediana não coincidem. O valor do coeficiente de assimetria não está muito próximo de zero, indicando haver certa assimetria na distribuição das concentrações deste elemento. $O$ coeficiente de curtose, por ser negativo, demonstra que a curva de distribuição é do tipo platicurtica.

A variabilidade para os resultados de $\mathrm{Zn}$ na folha é considerada média, pelo fato do valor do $\mathrm{CV}$ ter sido da ordem de $21,8 \%$. Uma grande dispersão para esses resultados é verificada, pois são elevados os valores de variância e desvio padrão, comparativamente com os mesmos parâmetros estatísticos calculados para os outros micronutrientes.

Na Figura 14 são apresentados o histograma, a reta de probabilidade normal e o gráfico de "Box-plot", para as concentrações Zn. O histograma mostra que a curva de distribuição apresenta formato achatado, como indicou o coeficiente de curtose. Verifica-se uma pequena assimetria à direita, em relação ao valor médio de $\mathrm{Zn}$. Na reta de probabilidade normal, os pontos apresentam uma certa flutuação no ajuste em relação à reta. Nota-se um imperfeito ajuste nos pontos localizados na metade inferior do gráfico.

Dentre os micronutrientes, o $\mathrm{Zn}$ é o micronutriente que apresenta as maiores respostas de produção na cultura do milho em solos brasileiros. Isso decorre da deficiência generalizada, principalmente em solos das regiões do Cerrado (Büll, 1993). A cultura do milho, em relação aos micronutrientes, apresenta alta sensibilidade somente à deficiência de Zn. Não há evidência da deficiência de Zn para as amostras coletadas na área de estudo, pois todas as concentrações estão acima do limite inferior para a faixa adequada, apresentada por Oliveira (2004), na cultura de milho sob Cerrado.

\subsubsection{Correlação com a Produtividade}

A análise estatística relevou que, em termos gerais, os coeficientes de correlação linear entre os atributos de nutrição mineral do milho, para a área de estudo, foram 
baixos e não significativos ao nível de $5 \%$ de probabilidade. Não foram considerados significativos os coeficientes de correlação entre a maioria dos atributos de nutrição mineral e os dados de produtividade média para cada célula de manejo. É destaque, porém, as correlações dos micronutrientes, $\mathrm{Cu}, \mathrm{Mn}$ e $\mathrm{Zn}$, as quais foram significativas e refletem o que foi discutido no capítulo três. Os coeficientes de correlação negativos para os esses micronutrientes versus produtividade estão diretamente ligados ao fornecimento anual desses nutrientes juntamente com as adubações. Como as determinações dos pHs do solo mostraram que o solo apresenta uma condição de média acidez, pode-se inferir uma maior disponibilidade dos micronitrientes catiônicos. Isto aliado ao fornecimento pelas adubações pode ter favorecido a ocorrência de toxidez por $\mathrm{Mn}$, causando efeito negativo na produtividade final. Logicamente, deve-se considerar que outros fatores de produção estiveram envolvidos no desempenho da cultura no campo.

Os dados de altitude mostraram ter uma relação mais direta com os atributos de nutrição mineral do milho, do que os dados de produtividade. Como pode ser verificado pelos coeficientes de correlação entre a altitude e esses atributos, que na sua maioria foram significativos. A análise estatística de correlação mostrou que há uma relação positiva entre os dados de altitude e produtividade.

Uma consideração importante são os valores dos coeficientes de correlação entre os macronutrientes absorvidos pela planta, que apresentaram uma magnitude maior em comparação com os demais coeficientes para as outras relações. Em especial, as relações entre o $\mathrm{N}$ e os demais macronutrientes demonstra que plantas bem nutridas em $\mathrm{N}$ são mais eficientes em absorver os outros nutrientes do solo. Porém esta relação foi inversa para o caso do $\mathrm{Mg}$.

$\mathrm{OK}$ foi o macronutriente que apresentou os maiores coeficientes de correlação com os micronutrientes. Observa-se relação negativa entre o $\mathrm{K}$ e os micronutrientes $\mathrm{Mn}$ e $\mathrm{Zn}$, absorvidos pela planta.

Dentre os micronutrientes, o B apresentou correlação significativa com os macronutrientes, a exceção do $\mathrm{Mg}$, com coeficientes muito próximos um do outro. Não houve correlação significativa entre o B e os demais micronutrientes. 
Para os micronutrientes $\mathrm{Cu}, \mathrm{Fe}, \mathrm{Mn}$ e $\mathrm{Zn}$, não houve correlação somente entre o $\mathrm{Cu}$ e $\mathrm{Fe}$, sendo positiva entre os micronutrientes $\mathrm{Cu}, \mathrm{Mn}$ e $\mathrm{Zn}$, e negativa entre $\mathrm{Fe}, \mathrm{Mn}$ e $\mathrm{Zn}$. 


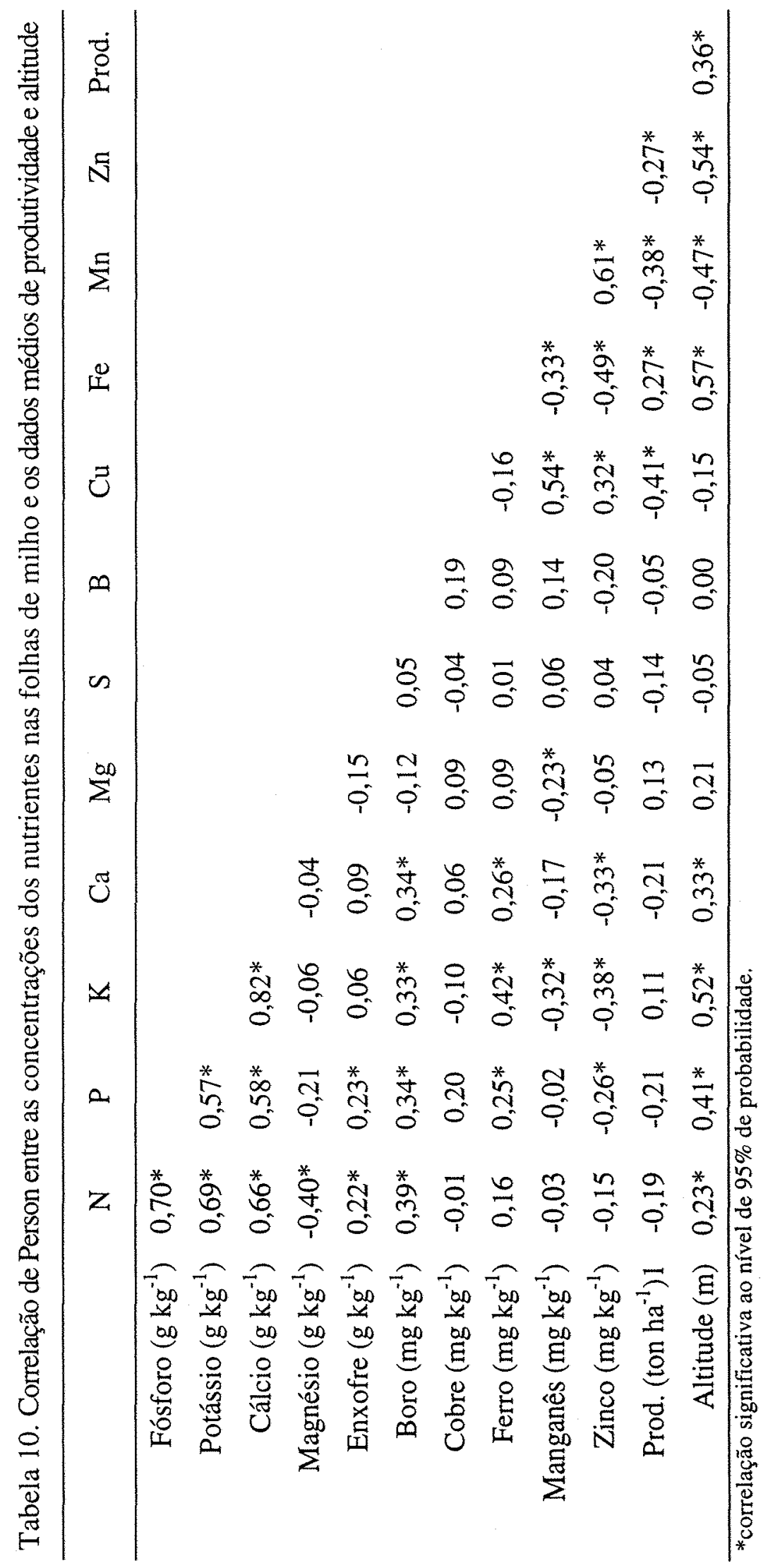


Partindo do conceito de que a disponibilidade dos nutrientes às plantas é influenciada, de forma direta, pelos atributos físicos do solo, de acidez e o teor de matéria orgânica, os resultados das concentrações de macro e micronutrientes obtidas em tecido foliar correlacionaram-se com alguns dos atributos determinados no solo (Tabela 11 e 12).

Os conteúdos de areia e argila apresentaram coeficientes de correlação significativos, somente para as concentrações de $\mathrm{K}$ e $\mathrm{Mg}$, entre os macronutrientes absorvidos pela planta (Tabela 11). Apesar se significativos esses coeficientes foram menores em comparação com os coeficientes de correlação entre a matéria orgânica e as concentrações desses nutrientes na folha. Pode-se inferir sobre a maior influência da matéria orgânica sobre a disponibilidade dos elementos as plantas. Isto demonstra que não só o aspecto físico do solo, como responsável pela dinâmica hídrica do solo, a qual contribui para a boa nutrição das plantas, mas também o teor de matéria orgânica que contribui para aumentar a capacidade de troca de cátions do solo, notadamente nas regiões de clima tropical, evitando-se perda de nutrientes.

As relações entre os conteúdos de areia e argila e as concentrações dos micronutrientes no tecido foliar foram significativas (Tabela 12). Essas relações foram negativas para o conteúdo de argila, a exceção do $\mathrm{Fe}$, mostrando que a disponibilidade dos micronutrientes diretamente pela textura do solo. Solos mais argilosos apresentam um teor maior de matéria orgânica, e esta por sua vez, pode-se ligar aos cátions metálicos presentes na solução do solo, deixando-os indisponíveis às plantas, como mostrou os coeficientes de correlação negativamente significativos entre a matéria orgânica e as concentrações de $\mathrm{Cu}, \mathrm{Mn}$ e $\mathrm{Zn}$.

Os coeficientes de correlação significativos, entre a acidez potencial do solo $(\mathrm{H}+\mathrm{Al})$ e os micronutrientes, a exceção do $\mathrm{Cu}$, provavelmente tenha sido reflexo da relação que existe entre eles e os componentes texturais do solo. 


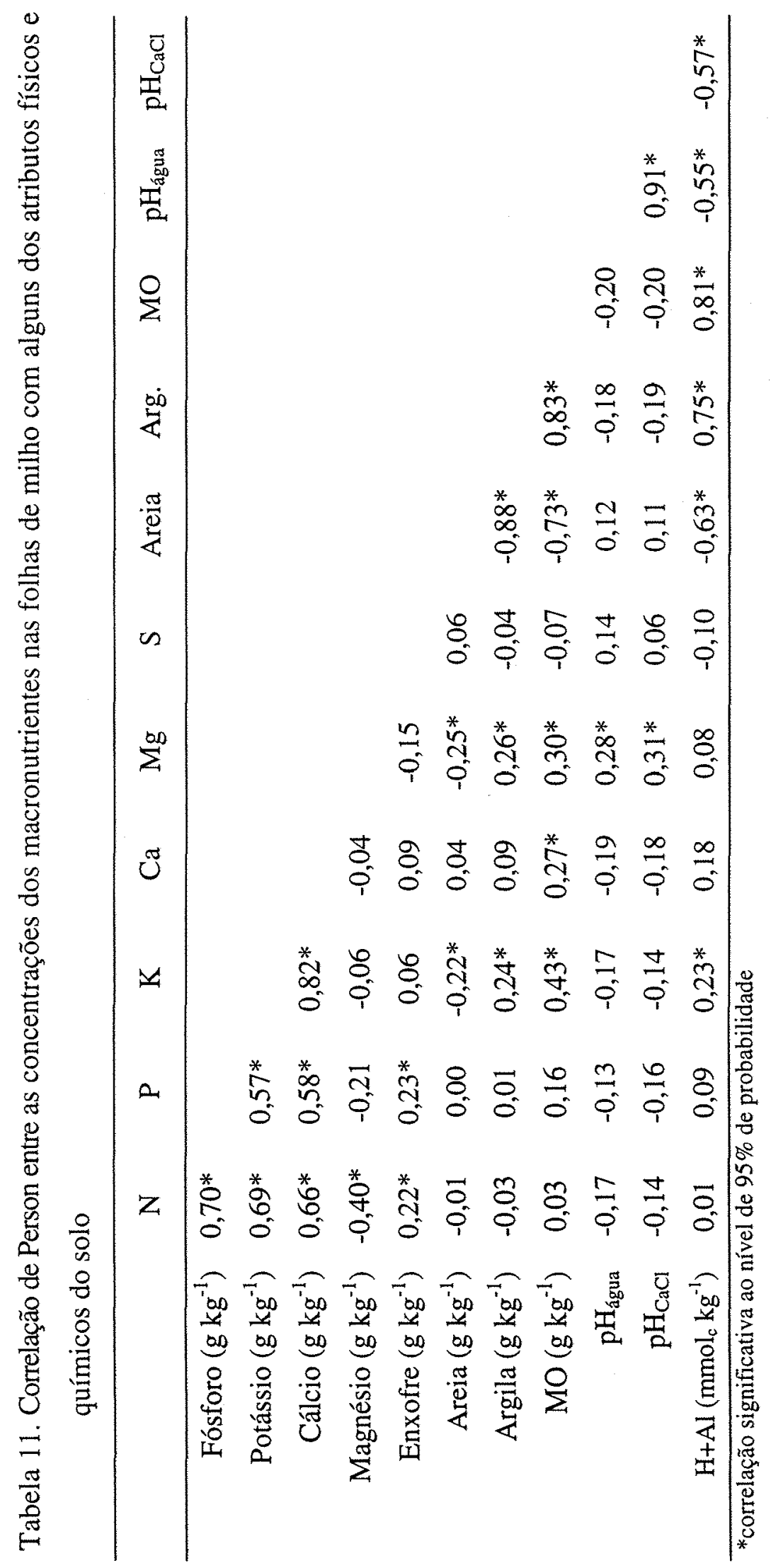




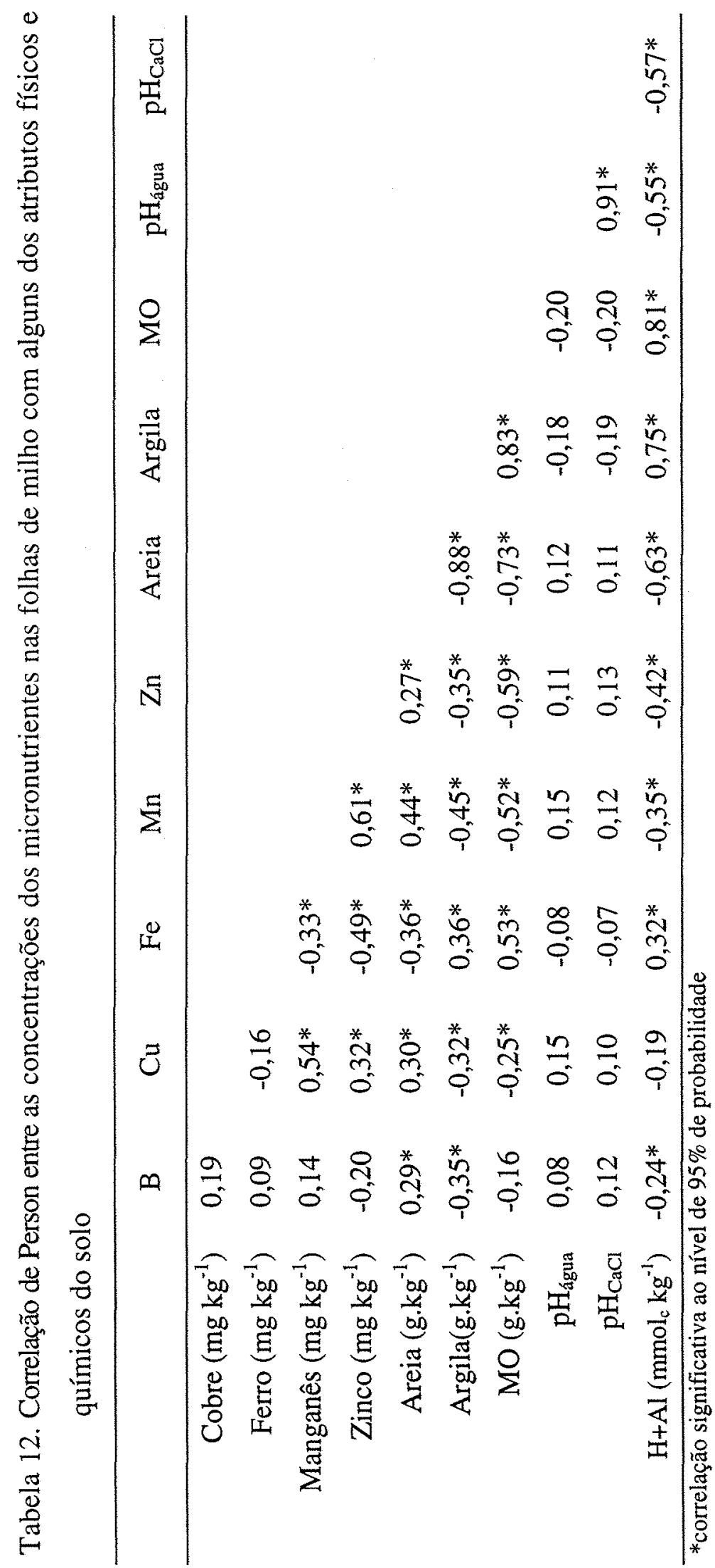




\subsection{Conclusões}

Os atributos considerados na nutrição mineral das plantas apresentaram baixa, média e alta variabilidade para a área de estudo.

A adubação anual com os micronutrientes, cobre, manganês e zinco na área de estudo não deve ser mais realizada por um período.

Neste tipo de estudo a altitude, medida indireta do relevo, deve ser considerada como uma variável importante para auxiliar no entendimento da produtividade obtida pela cultura. 


\section{CONCLUSÕES GERAIS}

Os atributos da fertilidade do solo e da nutrição mineral das plantas apresentaram baixa, média e alta variabilidade para a área em estudo.

A prática da correção da acidez do solo e adubações a serem realizadas na área do estudo devem considerar a variabilidade da fertilidade do solo e da nutrição mineral de plantas.

A adubação anual com os micronutrientes, cobre, manganês e zinco na área do estudo não deve ser mais realizada por um período.

Neste estudo a altitude, medida indireta do relevo, deve ser considerada como uma variável importante para auxiliar no entendimento da produtividade obtida pela cultura.

Em estudos de caso na escala de campo, as correlações lineares de variáveis com a produtividade da cultura são normalmente baixas, pois não é possível isolar todos os fatores envolvidos. 


\section{REFERÊNCIAS BIBLIOGRÁFICAS}

ADÁMOLI, J.; MACÊDO, J.; AZEVEDO, L.G.; MADEIRA NETTO, J. Caracterização da região dos cerrados. In: GOEDERT, W.J. (Ed.). Solos dos cerrados: tecnologias e estratégias de manejo. São Paulo: Nobel, 1987. cap.2, p.33-74.

BANZATO, D.A.; KRONKA, S.N. Experimentação agrícola. 3.ed. Jaboticabal: Funep, 1995. 247p.

BEIGUELMAN, B. Curso prático de bioestatística. 3.ed. Ribeirão Preto: Sociedade Brasileira de Genética, 1994. 224p.

BENNEMA, J. Calculation of CEC for grams clay (CEC) with correction for organic carbon. In: FAO. Report to the government of Brazil on classification of Brazilian soil. Rome, 1966. cap. 2, p.27-36.

BEYERS, D.W. Causal inference in environment impacts studies. Journal of the North American Benthological Society, v.17, p.367-373, 1998.

BOX, G.E.P.; HUNTER, W.G.; HUNTER, J.S. Statistics for experimenters: an introduction to design, data analysis and model building. New York: John Wiley, 1978. $653 \mathrm{p}$. 
BÜLL, L.T. Nutrição mineral do milho. In: BÜLL, L.T.; CANTARELLA, H. (Ed.). Cultura do milho: fatores que afetam a produtividade. Piracicaba: POTAFOS, 1993. cap. 5 , p.63-145.

CAHN, M.D.; HUMMEL, J.W.; BROUER, B.H. Spatial analysis of soil fertility for sitespecific crop management. Soil Science Society of America Journal, v.58, p.1240$1248,1994$.

CAMBARDELLA, C.A.; MOORMAN, T.B.; NOVAK, J.M.; PARKIN, T.B.; KARLEN, D.L.; TURCO, R.F.; KONOPKA, A.E. Field-scale variability of soil properties in Central Iowa Soils. Soil Science Society of America Journal, v.58, n.5, p.1501-1511, 1994.

CAMPOS, H. Estatística experimental não-paramétrica. 4.ed. Piracicaba: ESALQ, Departamento de Matemática e Estatística, 1983. 349p.

CANTARELLA, H. Calagem e adubação do milho. In: BÜLL, L.T.; CANTARELLA, H. (Ed.). Cultura do milho: fatores que afetam a produtividade. Piracicaba: POTAFOS, 1993. cap.6, p.147-196.

CARVALHO, M.P.; TAKEDA E.Y.; FREDDI, O.S. Variabilidade espacial de atributos de um solo sob videira em Vitória Brasil (SP). Revista Brasileira de Ciência do Solo, v. 27, n. 4, p. $695-703,2003$.

CARVALHO, O.S.; GASCÓ, J.M.; LOPÉZ, F.G.; REQUEJO, A.S. Variabilidade espacial de algumas propriedades químicas de um solo submetido a diferentes sucessões de cultivo. Revista Brasileira de Ciência do Solo, v.22, n.3, p.497-503, 1998. 
COMPANHIA NACIONAL DE ABASTECIMENTO. <http://conab.gov.br/>. (10 out. 2004)

DAVEY, B.J.; CONYERS, M.K. Determining the pH of acid soil. Soil Science, v.146, n.3, p.141-150, 1988 .

DOURADO NETO, D. Variabilidade espacial das alturas de chuvas e irrigação e de potencias da solução do solo. Piracicaba, 1989. 180p. Dissertação (Mestrado) - Escola Superior de Agricultura Luiz de Queiroz, Universidade de São Paulo.

EARL, R.; TAYLOR, J.C.; WOOD, G.A.; BRADLEY, R.I.; WAINE, T.; WELSH, J.P.; KNIGHT, S.M.; GODWIN, R.J. Soil factors and their influence on within-field crop variability, part I: field observation of soil variation. Biosystems Engineering, v.84, n.4, p.425-440, 2003.

EMPRESA BRASILEIRA DE PESQUISA AGROPECUÁRIA. Manual de métodos de análise do solo. Rio de Janeiro: EMBRAPA,CNPS, 1997. 212p.

FAO. Economic and social department. <http://faostat.fao.org/>. (11 out. 2004).

FNP CONSULTORIA \& COMÉRCIO. Agrianual 2004: anuário estatístico da agricultura brasileira. São Paulo, 2004. 496p.

GALRÃO, E.Z. Efeito de micronutrientes e do cobalto na produção e composição química do arroz, milho e soja em solo de cerrado. Revista Brasileira de Ciência do Solo, v.8, n. 1, p.111-116, 1984.

GALRÃO, E.Z. Micronutrientes. In: SOUSA, D.M.G; LOBATO, E. (Ed.). Cerrado: correção do solo e adubação. 2.ed. Brasília: EMBRAPA, 2004. cap.8, p.185-226. 
GALRÃO, E.Z.; SOUSA, D.M.G. Efeito do boro na esterilidade masculina do trigo em um solo orgânico de várzea. Revista Brasileira de Ciência do Solo, v.12, p.47-152, 1988.

GARCÍA y GARCÍA, A. Variabilidade espacial de atributos físicos do solo e resposta espectral da cultura de feijão irrigado, em imagens aéreas digitais. Piracicaba, 1997. 79p. Dissertação (Mestrado) - Escola Superior de Agricultura Luiz de Queiroz, Universidade de São Paulo.

GERBER, J.M. Farmer participation in research: a model for adaptive research and education. American Journal of Alternative Agriculture, v.7, p. 118-121, 1992.

GODWIN, R.J.; RICHARDS, T.E.; WOOD, G.A.; WELSH, J.P.; KNIGHT, S.K. An economic analysis of the potential for precision farming in UK cereal production. Biosystems Engineering, v.84, n.4, p.375-391, 2003.

GOEDERT, W.J. Região dos Cerrados: potencial agrícola e política para seu desenvolvimento. Pesquisa Agropecuária Brasileira, v.24, n.1, p.1-17, 1989.

GOEDERT, W.J. Management of the cerrado soils of Brazil: a review. Journal of Soil Science, v.34, p.405-428, 1983.

GOES, L.A.C. Estatística: uma abordagem decisorial. São Paulo: Saraiva, 1980. 428p.

GOMES, F.P. Curso de estatística experimental. 12.ed. Piracicaba: Nobel, 1987a. 467p.

GOMES, F.P. A estatística moderna na pesquisa agropecuária. 3.ed. Piracicaba: Potafos, 1987b. 162p. 
GONÇALVES, A.C.A. Variabilidade espacial de propriedades físicas do solo para fins de manejo da irrigação. Piracicaba, 1997. 118p. Tese (Doutorado) - Escola Superior de Agricultura Luiz de Queiroz, Universidade de São Paulo.

GUIMAR ÃES, E.C. Variabilidade da umidade e densidade do solo em um Latossolo Roxo. Campinas, 1993. 138p. Dissertação (Mestrado) - Faculdade de Engenharia Agrícola, Universidade Estadual de Campinas.

HANNAH, M.C. Usefully combining a series of unreplication cheesemaking experiments. Journal of Dairy Research, v.66, n.3, p.365-374, 1999.

HAWKINS, C.P. Pseudo-understanding of pseudoreplication: a cautionary note. Bulletin of Ecological Society of America, v.67, n.2, p.184-185, 1986.

HEUVEL, R.M. vanden. The promise of precision agriculture. Journal of Soil and Water Conservation, v.51, n.1, p.38-40, 1996.

HOAGLIN, D.C.; MOSTELLER, F.; TUKEY, J.W. Understanding robust and exploratory data analysis. New York: John Wiley, 1983. 446p.

IKERD, J.E. The question of good science. American Journal of Alternative Agriculture, v.8, n.2, p.91-92, 1993.

JOHNSON, C.K.; ESKRIDGE, K.M.; WIENHOLD, B.J.; DORAN, J.W.; PETERSON, G.A.; BUCHLEITER, G.W. Using Electrical Conductivity Classification and WithinField Variability to Design Field-Scale Research. Agronomy Journal, v.95, n.2, p.602$613,2003$. 
JOHNSON, J.J.; ALLDREDGE, J.R.; ULLRICH, S.E.; DANGI, O. Replacement of replications with additional locations for grain sorghum cultivar evaluation. Crop Science, v.32, p.43-46, 1992.

JONES, T.A. Skewness and Kurtosis as criteria of normality in observed frequency distributions. Journal of Sedimentary Petrology, v. 39, p. 1622-1627, Dec. 1969.

LANDIM, P.M.B. Introdução à geoestatística. Rio Claro: UNESP, 1998. 114p. (Publicação Didática, 3).

LENTNER, N.R.; BISHOP, T. Experimental design and analysis. Blacksbury: Valley Book Company, 1993. 512p.

LEVINE, D.M.; BERENSON, M.L.; STEPHAN, D. Estatística: teoria e aplicações. Trad. de T.C.P. de Souza. Rio de Janeiro: LTC, 2000. 812p.

LIBARDI, P.L; MANFRON, P.A; MORAES, S.O. de; TUON, R.L. Variabilidade da umidade gravimétrica de um solo hidromórfico. Revista Brasileira de Ciência do Solo, v.20, p.1-12, 1996.

LINDSAY, W.L.; NORVELL, W.A. Development of a DTPA soil test for zinc, iron, manganese and copper. Soil Science Society of America Journal, v.42, p.421-428, 1978 .

LOCKERETZ, W. Establishing the proper role for on farm research. American Journal of Alternative Agriculture, v.2, p.132-136, 1987.

LOPES, A.S. A survey of the fertility status of soil under cerrado vegetation in Brazil. Raleigh, 1975. 138p. Dissertation (M.Sc.) - North Carolina State University. 
LOPES, A.S. Solos sob cerrado: características, propriedades e manejo. Piracicaba: Potafos, 1983. 162p.

LOPES, A.S.; COX, F.R. A survey of the fertility status of surface soils under cerrado vegetation in Brazil. Soil Science Society of America Proceedings, v.4, p.742-747, 1977.

MALAVOLTA, E.; VITTI, G.C.; OLIVEIRA, S.A. Avaliação do estado nutricional das plantas. 2.ed. Piracicaba: Potafos, 1997. 319p.

MARTENS, D.C.; WERTERMANN, D.T. Fertilizer applications for correcting micronutrient deficiencies. In: MICKELSON, S.H. (Ed.). Micronutrients in agriculture. 2.ed. Madison:SSSA, 1991. p.549-592.

McBRIDE, M.B. Environmental chemistry of soils. New York: Oxford University Press, 1994. $406 \mathrm{p}$

MORAES, S.O. Heterogeneidade hidráulica de uma Terra Roxa Estruturada. Piracicaba, 1991. 141p. Tese (Doutorado) - Escola Superior de Agricultura Luiz de Queiroz, Universidade de São Paulo.

MORAES, S.O.; LIBARDI, P.L.; REICHARDT, K. Heterogeneidade dos pontos experimentais de curva de retenção de água no solo. Scientia Agricola, v.50, n.3, p.393$403,1993$.

MOREAU, L; MONOD, H; CHARCOSSET, A.; GALLAIS, A. Marker-assisted selection with special analysis of unreplicated field trials. Theoretical and Applied Genetics, v.98, n.2, p.234-242, 1999. 
MULLA, D.J.; McBRATNEY, A.B. Soil spatial variability. In: SUMNER, M.E. (Ed.). Handbook of soil science. New York: CRC Press, 2000. cap.9, p.321-352.

NIELSEN, D.R.; BIGGAR, W; ERB, K.T. Spatial variability of field-measured soil-water properties. Hilgardia, v.42, n.7, p.215-259, 1973.

NORMAN, D.W.; BLOOMQUIST, L.E; FREYENBERGER, S.G.; REGEHR, D.L., SCHURLE, B.W.; JANKE, R.R. Farmers attitudes concerning on farm research: Kansas survey results. Journal of Natural Resources and Life Science Education, v.27, p.35$41,1998$.

OLIVEIRA, J.B. de. Variação de características morfológicas, físicas e mineralógicas em duas áreas de oxissolo. Piracicaba, 1973. 199p. Tese (Doutorado) - Escola Superior de Agricultura Luiz de Queiroz, Universidade de São Paulo.

OLIVEIRA, J.J.; CHAVES, L.H.G.; QUEIROZ, J.E.; LUNA, J.G. Variabilidade espacial de propriedades químicas em um solo salino-sódico. Revista Brasileira de Ciência do Solo, v.23, n.4, p.783-789, 1999.

OLIVEIRA, S.A. Análise foliar. In: SOUSA, D.M.G; LOBATO, E. (Ed.). Cerrado: correção do solo e adubação. 2.ed. Brasília: EMBRAPA, 2004. cap.10, p.245-256.

PAZ, A; TABOADA, M.T; GÓMEZ, M.J. Spatial variability in topsoil micronutrient contents in a one-hectare cropland plot. Communications in Soil Science and Plant Analysis, v.27, n.3/4, p.479-503, 1996.

QUAGGIO, J.A.; RAMOS, V.J.; BATAGLIA, O.C.; RAIJ, B. van; SAKAI, M. Calagem para a sucessão batata-triticale-milho usando calcários com diferentes teores de magnésio. Bragantia, v.44, p.391-406, 1985. 
RAIJ, B. van. Fertilidade do solo e adubação. Piracicaba: Ceres; Potafos, 1991. 343p.

RAIJ, B. van; ANDRADE, J.C de.; CANTARELA, H; QUAGGIO, J.A. Análise química para avaliação da fertilidade de solos tropicais. Campinas: Instituto Agronômico, 2001. $285 \mathrm{p}$.

RAIJ, B. van; CANTARELLA, H.; QUAGGIO, J.A.; FURLANI, A.M.G. Recomendações de adubação e calagem para o Estado de São Paulo. 2.ed. Campinas: Instituto Agronomico/Fundação IAC, 1997. 285p. (Boletim técnico, 100)

REICHARDT, K; VIEIRA, S.R.; LIBARDI, P.L. Variabilidade espacial de solos e experimentação de campo. Revista Brasileira de Ciência do Solo, v.10, n.1, p.1-6, 1986.

REIN, T.A.; SOUSA, D.M.G. Adubação com enxofre. In: SOUSA, D.M.G.; LOBATO, E. (Ed.). Cerrado: correção do solo e adubação. 2.ed. Brasília: EMBRAPA, 2004. cap.9, p. $227-244$.

RITCHEY, K.D.; COX, F.R; GALRÃO, E.Z; YOST, R.S. Disponibilidade de zinco para as culturas de milho, sorgo e soja num Latossolo Vermelho-Escuro argiloso. Pesquisa Agropecuária Brasileira, v.21, p.215-225, 1986.

RZEWNICKI, P. Farmer's perceptions of experiment station research, demonstrations, and on farm research in agronomy. Journal of Agricultural Education, v.20, p.31-36, 1991

SALVIANO, A.A.C. Variabilidade de atributos de solo e de Crotalaria juncea em solo degradado do município de Piracicaba-SP. Piracicaba, 1996. 91p. Tese (Doutorado) Escola Superior de Agricultura Luiz de Queiroz, Universidade de São Paulo. 
SALVIANO, A.A.C.; VIEIRA, S.R.; SPAROVEK, G. Variabilidade espacial de atributos de solo e de Crotalaria juncea L. em área severamente erodida. Revista Brasileira de Ciência do Solo, v.22, n.1, p.115-122, 1998.

SCHOFIELD, R.K; TAYLOR, A.W. The measurement of soil pH. Soil Science Society of America Proceedings, v.19, n.2, p.164-167, 1955.

SILVEIRA, P.M. da; CUNHA, A.A. da. Variabilidade de micronutrientes, matéria orgânica e argila de um Latossolo submetido a sistemas de preparo. Pesquisa Agropecuária Brasileira, v.37, n.9, p. 1325-1332, 2002.

SILVEIRA, P.M. da; ZIMMERMANN, F.J.P.; SILVA, S.C. da; CUNHA, A.A. da. Amostragem e variabilidade espacial de características químicas de um Latossolo submetido a diferentes sistemas de preparo. Pesquisa Agropecuária Brasileira, v.35, n. 10, p.2057-2064, 2000.

SOUSA, D.M.G. Fertilidade do solo e suas relações com as produtividades das culturas de soja e milho nos Cerrados do médio Araguaia. Água Boa: COOPERCANA, 1988. $70 \mathrm{p}$.

SOUSA, D.M.G.; LOBATO, E. (Ed.). Cerrado: correção do solo e adubação. 2.ed. Brasília: EMBRAPA, 2004. 416p.

SOUSA, D.M.G.; LOBATO, E.; REIN, T.A. Adubação com fósforo. In: SOUSA, D.M.G.; LOBATO, E. (Ed.). Cerrado: correção do solo e adubação. 2.ed. Brasília: EMBRAPA, 2004. cap. 6 , p. 147-168.

SOUSA, D.M.G.; MIRANDA, L.N.; LOBATO, E. Avaliação dos métodos de determinação da necessidade de calcário em solos de cerrado. Planaltina: EMBRAPA, CPAC, 1990. 14p. 
SOUZA, L.S. Variabilidade espacial do solo em sistemas de manejo. Porto Alegre, 1992. 162p. Tese (Doutorado) - Universidade Federal do Rio Grande do Sul.

SOUZA, L.S.; COGO, N.P.; VIEIRA, S.R. Variabilidade de propriedades físicas e químicas em um pomar cítrico. Revista Brasileira de Ciência do Solo, v.21, p.367-372, 1997.

SOUZA, L.S.; COGO, N.P.; VIEIRA, S.R. Variabilidade de fósforo, potássio e matéria orgânica no solo em relação a sistemas de manejo. Revista Brasileira de Ciência do Solo, v.22, p.77-86, 1998.

SPIEGEL, M.R. Estatística. 2.ed. Trad. de C.A. Crusius. São Paulo: McGraw-Hill, 1985. $454 \mathrm{p}$.

STEWART-OATEN, A.; MURDOCK, W.W.; PARKER, K.R. Environmental impact assessment: "Pseudoreplication" in time? Ecology, v.67, n.4, p.929-940, 1986.

TAYLOR, J.C.; WOOD, G.A.; EARL, R., GODWIN, R.J. Soil Factors and their Influence on Within-field Crop Variability, Part II: Spatial Analysis and Determination of Management Zones. Biosystems Engineering, v.84, n.4, p.441-453, 2003.

TRANGMAR, B.B.; YOST, R.S.; UEHARA, G. Application of geostatistics to spatial studies of soil properties. Advances in Soil Science, v.38, p.45-94, 1985.

VERDÉSIO, J.J. Os cerrados do oeste da Bahia: descrição física e potencial de uso agrícola. Salvador: SEPLANTE/CAR, 1986, 78p.

WARRICK, A.W.; NIELSEN, D.R. Spatial variability of soil physical properties in the field. In: HILLEL, D. (Ed.). Applications of soil physics. New York: Academic Press, 1980. cap. 13, p.319-344. 
WATKINS, G. Participatory research: a farmer's perspective. American Journal of Alternative Agriculture, v.5, p.1069-1083, 1990.

WIENS, J.A.; PARKER, K.R. Analyzing the effects of occidental environmental impacts: approaches and assumptions. Ecological Applications, v.5, n.4, p. 1069-1083, 1995. 